\title{
5. LOCALIZATION OF DUCTILE STRAIN AND THE MAGMATIC EVOLUTION OF GABBROIC ROCKS DRILLED AT THE MID-ATLANTIC RIDGE $\left(\mathbf{2 3}^{\circ} \mathrm{N}\right)^{1}$
}

\author{
Mathilde Cannat, ${ }^{2}$ Georges Ceuleneer, ${ }^{3}$ and John Fletcher ${ }^{4}$
}

\begin{abstract}
Ductile deformation of gabbroic rocks drilled on the west wall of the Mid-Atlantic Ridge south of the Kane Fracture Zone (Sites 921-923) localizes preferentially in gabbronoritic intervals. The least evolved gabbroic lithologies (troctolites) are rarely deformed, and the most evolved ones (leucocratic segregations) are not deformed. A close look at ductile shear zones and at their mineral chemistry suggests that, in many cases, they developed in gabbronoritic dikelets intruded into less evolved lithologies. Recrystallized phase assemblages are similar to igneous ones in most deformed samples. This indicates that ductile deformation occurred in high-temperature nearly anhydrous conditions similar to magmatic conditions. Compositional variations in igneous and recrystallized minerals in many shear zones also suggest that ductile deformation took place with some residual melt present. The presence of interstitial melt in shear zones during deformation would produce a strong rheological contrast between material in the shear zone and the surrounding rocks. The range of gabbroic lithologies drilled at Sites 921923 , their relative proportions in the core, the composition of igneous minerals, the preferred localization of ductile deformation in gabbronoritic lithologies, and the probable role of trapped fractionated melts in favoring this strain localization recall observations made in gabbroic rocks from Site 735 in the Southwest Indian Ocean.
\end{abstract}

\section{INTRODUCTION}

Gabbroic rocks exposed along the median valley walls of midocean ridges represent magmas that pooled and crystallized at some depth below the axial seafloor and were subsequently exhumed and emplaced into the upper crust. These rocks give us an opportunity to study processes active in the deep axial magma plumbing system, a system that is commonly out of the reach of sampling techniques and can only be approached through geophysical experiments.

The emplacement of gabbroic rocks to the seafloor is restricted to portions of the world ridge system that have a deep and wide axial valley and that commonly are near axial, transform or "non-transform" discontinuities. This is the case for the gabbroic exposures of the Mid-Atlantic Ridge near the Kane Fracture Zone (MARK area; Fig.1). Submersible studies in this region (Dick et al., 1981; Karson et al., 1987; Mével et al., 1991; Auzende et al., 1993) have shown that the gabbroic rocks are exposed along low-dipping normal fault planes. These fault surfaces were drilled through during Leg 153 and extensively cataclased fault rocks were recovered in the core (Cannat, Karson, Miller, et al., 1995). The existence of such faults and the accentuated relief of the axial valley are both consistent with the hypothesis that plate divergence in this region, and more generally in regions where rocks that formed deep below the seafloor (serpentinized peridotites or gabbroic rocks) are exposed in the seafloor, involves a large component of tectonic extension (Dick et al., 1981; Karson et al., 1987; Karson, 1990; Cannat, 1993). If this is indeed the case, there must be evidence for tectonic extension not only in the uppermost, brittle part of the axial lithosphere, but also in its deeper and hotter parts. Rocks that have been exhumed from these deeper litho-

'Karson, J.A., Cannat, M., Miller, D.J., and Elthon, D. (Eds.), 1997. Proc. ODP, Sci. Results, 153: College Station, TX (Ocean Drilling Program).

${ }^{2}$ Laboratoire de Pétrologie-URA CNRS 736, Université Pierre et Marie Curie, 4 place Jussieu, 75252 Paris cedex 05, France. mac@ccr.jussieu.fr

${ }^{3}$ Observatoire Midi-Pyrénées, CNRS-UPR 234, 14 av. E. Belin, 31400 Toulouse, France.

"Departamento de Geologia, CICESE P.O. Box 434843, San Diego, CA 921434843 , U.S.A.

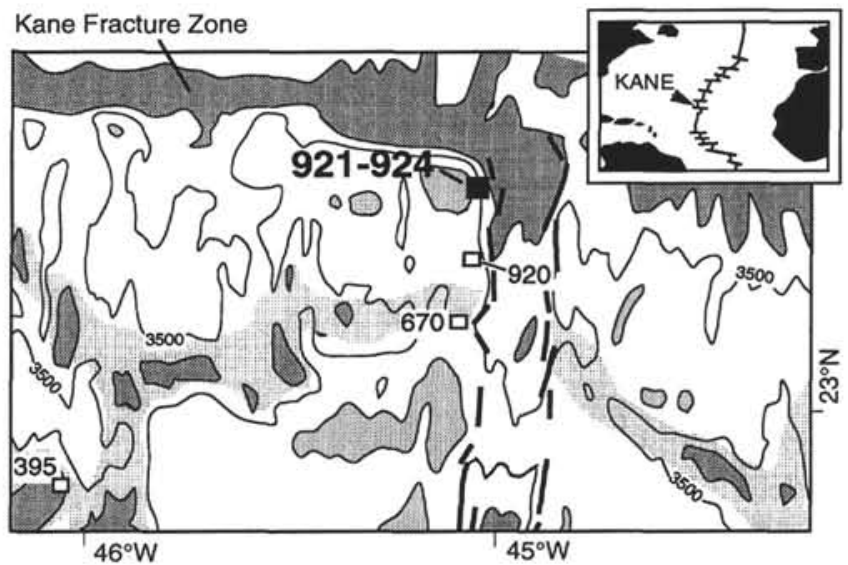

Figure 1. Simplified bathymetric map of the MARK area (after Gente et al., 1995) showing the location of Sites 395 (Deep Sea Drilling Project Leg 45; serpentinized peridotites and gabbro), 670 (ODP Leg 109; serpentinized peridotites), 920 (Leg 153; serpentinized peridotites and gabbro), and 921924 (this study). Bathymetric contours: $4000 \mathrm{~m}$ (domains deeper than 4000 $\mathrm{m}$ in dark gray), $3500 \mathrm{~m}$, and $2500 \mathrm{~m}$ (domains shallower than $2500 \mathrm{~m}$ in lighter gray). Heavy lines show the median valley main scarps. Alignments of basins, interpreted as marking the off-axis trace of axial discontinuities, are outlined in an intermediate shade of gray.

spheric levels should therefore be affected by high-temperature, brittle-ductile, and ductile extensional deformation.

Drilling at Site 735 during Ocean Drilling Program (ODP) Leg 118 provided ample evidence for such high-temperature extensional deformation in exhumed gabbroic rocks from the Southwest Indian Ridge (Cannat et al., 1991; Dick et al., 1991). A large proportion of the gabbroic rocks that have been sampled during submersible, dredging, or during other drilling legs in various parts of the world's slow-spreading ridge system are similarly deformed (Helmstaedt and Allen, 1977; Ito and Anderson, 1983; Mével and Cannat, 1991; Cannat and Casey, 1995). 
Gabbroic core totaling $78.5 \mathrm{~m}$ was recovered during Leg 153 on the west wall of the Mid-Atlantic Ridge axial valley, a few kilometers to the south of the Kane Fracture Zone (Fig. 1). These gabbroic rocks show striking similarities to the Site 735 rocks, both in terms of mineralogy and magmatic evolution (Ross and Elthon, this volume; $\mathrm{Ca}$ sey, this volume; this study) and of deformational microstructures (Fletcher, Ceuleneer, et al., this volume). The core from the MARK area sites is, however, not nearly as extensively sheared as the core from Site 735. Meter- to decameter-thick intervals of gabbroic ductile mylonites were recovered at Site 735. Mylonitic gabbros drilled at the MARK sites form decimeter-thick intervals at most (Fig. 2). Although not as spectacular in terms of displacement as the mylonites recovered from Site 735 , these thin shear zones give us the opportunity to study the initial stages of ductile strain localization in the gabbros and their relationships with fine-scale magmatic features in the core.

Many mylonitic shear zones in the gabbroic rocks drilled at Site 735 in the southwest Indian Ocean occur in evolved oxide-bearing gabbros, suggesting an interplay between the localization of ductile deformation and the distribution of fractionated melts in the solidifying gabbro pile (Bloomer et al., 1991; Dick et al., 1991). Our aim in this paper is to check whether a comparable interplay existed in the MARK area gabbroic rocks. We have examined the mineralogy of ductile shear zones cored at Sites 921-923, and conducted detailed microprobe analyses of igneous and dynamically recrystallized minerals in a set of samples selected after a macroscopic survey of the core and after viewing about 300 thin sections (the shipboard thin sections listed in Cannat, Karson, Miller, et al., 1995, and the set of thin sections studied by Fletcher, Ceuleneer, et al., this volume). We believe that these selected samples are representative of the mineralogical variety in ductile shear zones that have been recovered at Sites 921-923. Over $70 \%$ of the material drilled in the eight shallow holes at these sites has, however, not been recovered (Table 1; Cannat, Karson, Miller, et al., 1995). This lost material presumably also included ductile shear zones, some of which may have been different from those that have been recovered. The results presented in this paper will be discussed with this limitation in mind.

\section{DUCTILE SHEAR ZONES: IGNEOUS AND RECRYSTALLIZED MINERALOGY}

The gabbroic rocks cored at the MARK area sites are troctolites, olivine gabbros (volumetrically the predominant rock type), gabbros, gabbronorites, oxide gabbronorites, olivine gabbronorites, and norites, as well as small volumes of leucocratic, commonly quartzbearing, segregates (Cannat, Karson, Miller, et al., 1995). This range of mineralogy, similar to that sampled at Site 735 in the Southwest Indian Ocean (Shipboard Scientific Party, 1989), corresponds to a wide range of mineral compositions and to large differences in the degree of magmatic fractionation. Again, similar to what was observed at Site 735 , these various rock types are interspersed over short lengths of core (at scales of a few centimeters to a few meters) in no stratigraphic order.

\section{Igneous Mineralogy and the Distribution of Ductile Strain}

The downhole distribution and the fabrics of deformed intervals at Sites 921, 922, and 923 are described by Fletcher, Ceuleneer, et al. (this volume). Here, we use a simplified version of the textural systematics described in their paper, based on the proportion of plagioclase grains that we infer to be dynamically recrystallized: $0 \%$ recrystallized plagioclase corresponds to textural type $1 ;<30 \%, 30 \%-70 \%$, $70 \%-90 \%$, and $>90 \%$ recrystallized plagioclase correspond to textural types $1,2,3$, and 4 , respectively.
We use this proportion of recrystallized over igneous plagioclase as a qualitative indicator of the intensity of ductile deformation in our samples. Plagioclase grains that we interpret as dynamically recrystallized are smaller than the surrounding igneous plagioclase, and are equant as well as commonly polygonal in shape. Their size is variable, possibly reflecting variations of the physical conditions during ductile deformation (Cannat, Karson, Miller, et al., 1995; Fletcher, Ceuleneer, et al., this volume). In samples that contain more than $30 \%$ recrystallized plagioclase, igneous grains of olivine and pyroxene are commonly surrounded by smaller equant and polygonal grains of the same minerals also inferred to be dynamically recrystallized. The reader is referred to Fletcher, Ceuleneer, et al. (this volume) for microstructural details and for a discussion of deformation mechanisms. The textural systematics we use here are based on plagioclase because it is present in large amounts in all gabbroic lithologies, and because it appears to be dynamically recrystallized in all deformed samples (Cannat, Karson, Miller, et al., 1995; Fletcher, Ceuleneer, et al., this volume).

Table 2 and Figure 3 show that there is a definite correlation, in gabbroic rocks from Sites 921 to 923 , between igneous mineralogy and the degree of plagioclase recrystallization (inferred to give an indication on the amount of ductile strain). Troctolites represent $18.4 \%$ of the 315 gabbroic samples we have examined in thin sections. $43.1 \%$ of these troctolitic samples do not contain recrystallized plagioclase, and plagioclase in $87.9 \%$ of these samples is less than $30 \%$ recrystallized (Fig. 3). By contrast, the proportion of recrystallized plagioclase is more than $70 \%$ in $68.6 \%$ of gabbronoritic samples (gabbronorites, oxide gabbronorites, olivine gabbronorites, and norites), and only $3.9 \%$ of these gabbronoritic samples do not contain recrystallized plagioclase. Ductile deformation, therefore, appears to have localized preferentially in gabbronoritic intervals, most of the less-evolved troctolites and olivine gabbros being weakly deformed or undeformed. Leucocratic segregations are systematically undeformed.

The distribution of igneous lithologies and of textural types listed for the 315 gabbroic samples considered in Table 2 is not representative of the gabbroic section recovered at Sites 921-923. It is biased toward the more deformed samples, and, therefore, it also overestimates the proportion of gabbronoritic intervals. The relative proportions of igneous lithologies, and of textural types in a subset of these 315 samples that corresponds to the thin sections made on board the JOIDES Resolution during Leg 153 (Cannat, Karson, Miller, et al., 1995 ), are probably closer to actual proportions in the recovered gabbroic section. In this subset of samples (132 samples; Table 2), gabbroic rocks with no recrystallized plagioclase represent $44.7 \%$, whereas sheared intervals with more than $70 \%$ recrystallized plagioclase represent only $8.4 \%$.

\section{Ductile Shear Zones: Macroscopic Description and Mineral Assemblages}

Intervals of pronounced ductile deformation (textural types 3 and 4) have a well-defined foliation (Fig. 2). They are commonly only a few millimeters to a few centimeters thick (Fig. 2A). The decimeterthick shear zones shown in Figures $2 \mathrm{~B}$ and $2 \mathrm{C}$ are uncommon features in the core. There are, however, moderately deformed (textural type 2), weakly foliated intervals of gabbro and olivine gabbro that extend over a few meters of core (Cannat, Karson, Miller, et al., 1995).

Some shear zones develop in oxide-bearing intervals (Fig. 2A), others develop in oxide-free lithologies. There are also centimeterthick intervals of oxide-bearing gabbro that form dikelets and seams in the surrounding rocks and are undeformed, or are weakly foliated (Fig. 4), with moderately recrystallized plagioclase (textural type 2). The mineralogical characteristic shared by most deformed intervals 


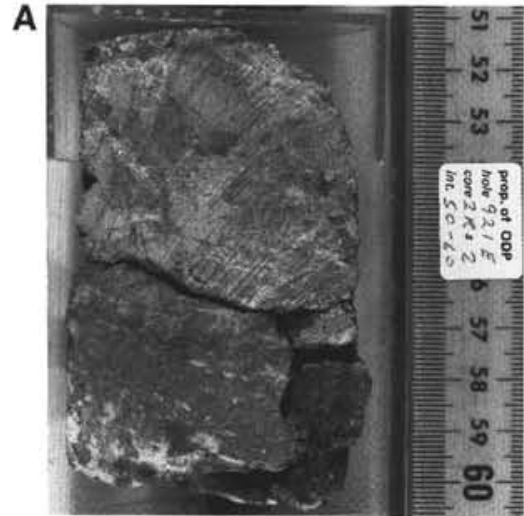

B

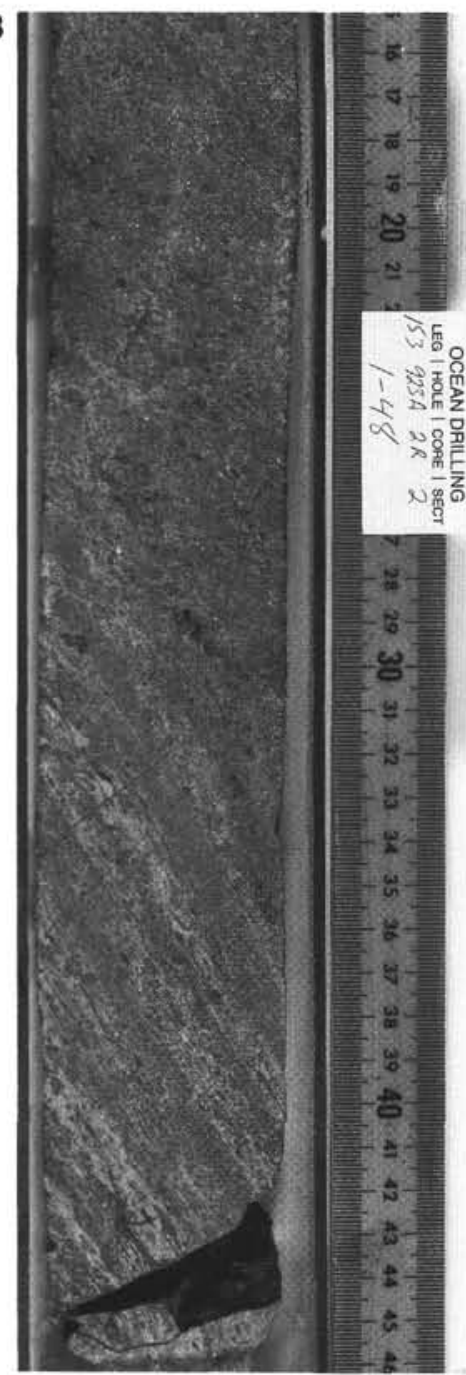

C

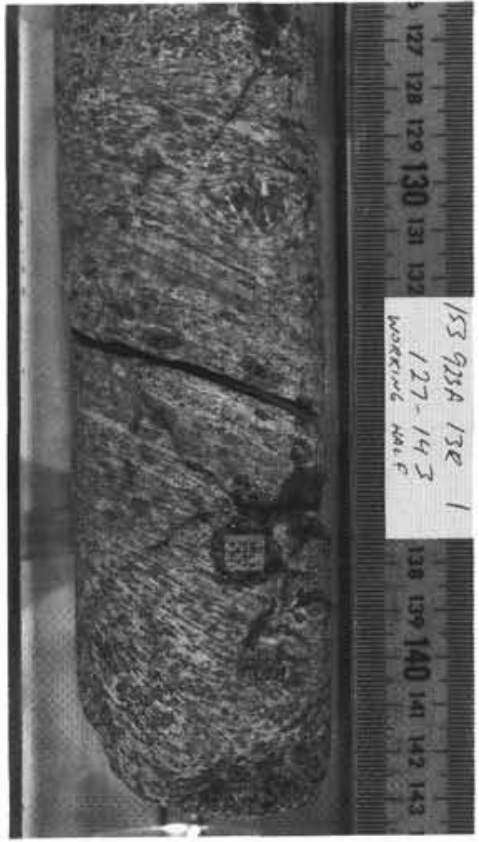

D

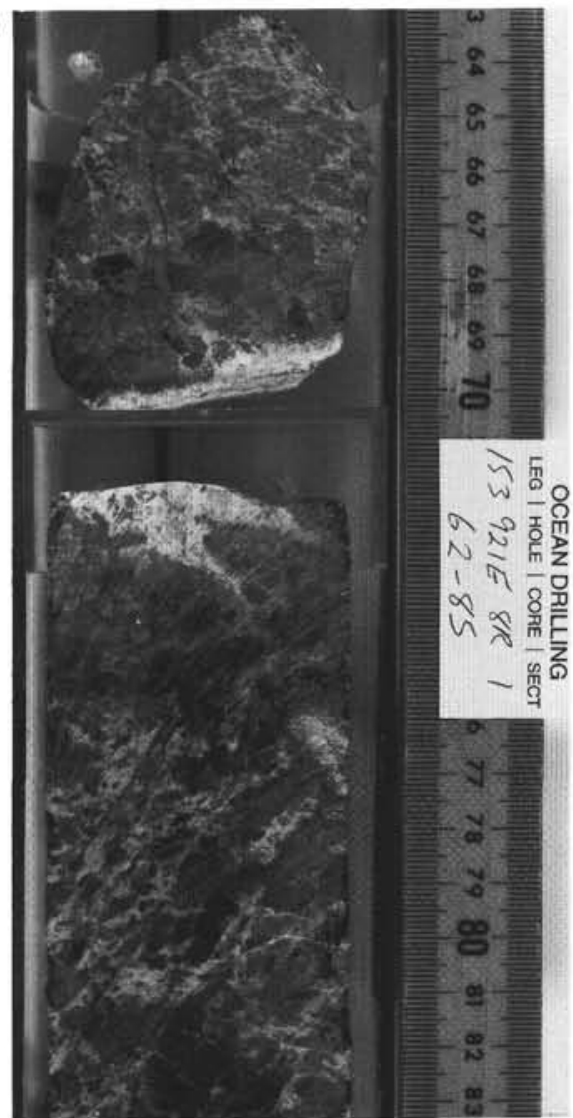

Figure 2. Core photographs. A. Sample 153-921E-2R-2, 51-60 cm. Mylonitic interval of oxide gabbronorite (57-60 cm) in weakly deformed coarse-grained olivine gabbro $(51-57 \mathrm{~cm}$ ). B. Sample 153-923A-2R-2, 22-45 cm. Shear zone with steep foliation cutting through undeformed olivine gabbro (22-37 $\mathrm{cm}$ on right side of photograph). The shear zone contains bands of finely recrystallized olivine-bearing microgabbronorite and coarser grained bands (lighter in photograph) of foliated gabbronorite. C. Sample 153-923A-13R-1, 126-142 cm. Shear zone with low-dipping foliation developed in medium-grained olivine gabbro (less deformed intervals), and finer grained gabbronorite (photomicrographs in Figs. 5D, 5F). D. Interval 153-921E-8R-1, 64-83 cm. Moderately deformed, coarse-grained olivine-bearing gabbro with white seams that outline an irregular foliation and that are produced by recrystallized plagioclase and by undeformed, fine-grained leucocratic segregations, along grain boundaries, and in fractures (similar to photomicrograph in Fig. 5C). Coarser grained, undeformed leucocratic segregations form a vein at $69-73 \mathrm{~cm}$. 
Table 1. Location and drilling record from Sites 921 to 923 (Cannat, Karson, Miller, et al., 1995).

\begin{tabular}{ccccc}
\hline Hole & $\begin{array}{c}\text { Latitude } \\
(\mathrm{N})\end{array}$ & $\begin{array}{c}\text { Longitude } \\
(\mathrm{W})\end{array}$ & $\begin{array}{c}\text { Cored } \\
(\mathrm{mbs})\end{array}$ & $\begin{array}{c}\text { Recovered } \\
(\mathrm{m})\end{array}$ \\
\hline 921A & $23^{\circ} 32.46^{\prime}$ & $45^{\circ} 01.86^{\prime}$ & 17.1 & 3.1 \\
$921 \mathrm{~B}$ & $23^{\circ} 32.48^{\prime}$ & $45^{\circ} 01.84^{\prime}$ & 44.1 & 10.2 \\
$921 \mathrm{C}$ & $23^{\circ} 32.47^{\prime}$ & $45^{\circ} 01.83^{\prime}$ & 53.4 & 6.1 \\
$921 \mathrm{D}$ & $23^{\circ} 32.44^{\prime}$ & $45^{\circ} 01.83^{\prime}$ & 48.6 & 6.16 \\
$921 \mathrm{E}$ & $23^{\circ} 32.33^{\prime}$ & $45^{\circ} 01.88^{\prime}$ & 82.6 & 17.65 \\
$922 \mathrm{~A}$ & $23^{\circ} 31.37^{\prime}$ & $45^{\circ} 01.92^{\prime}$ & 14.6 & 9.23 \\
$922 \mathrm{~B}$ & $23^{\circ} 31.37^{\prime}$ & $45^{\circ} 01.92^{\prime}$ & 37.4 & 11.9 \\
$923 \mathrm{~A}$ & $23^{\circ} 32.55^{\prime}$ & $45^{\circ} 01.89^{\prime}$ & 70.0 & 40.7 \\
\hline
\end{tabular}

Note: $\mathrm{mbsf}=$ meters below seafloor.

with type 3 or 4 textures is that they contain orthopyroxene, as igneous porphyroclasts, recrystallized grains, or both (Table 3 ).

Ductile shear zones at Sites 921-923 also typically have sharp contacts with the surrounding, less deformed to undeformed, gabbroic rocks (Figs. 2A, 5A, 5D), and these contacts commonly coincide with lithological contacts. Samples selected for microprobe analyses in this paper commonly include such deformational and lithological contacts (Table 3). Consistent with the data shown in Table 2, many of these contacts involve troctolites or olivine gabbro on the undeformed to weakly deformed side, and gabbronoritic lithologies on the strongly deformed side (Figs. 2A, 5A, 5D; Table 3). In many samples, there also is a marked change in the size of igneous minerals across these deformational and lithological contacts, the most deformed material containing smaller igneous minerals. Smaller igneous grain sizes in the most deformed intervals could result from recrystallization. It is, however, common to observe in the recrystallized matrix small pyroxene grains that have retained euhedral igneous shapes (Figs. 5D, 5E) and may therefore be representative of original igneous grain sizes. There are occasional dikelets of finegrained gabbronorite in the core (e.g., Sample 153-12R-2, 26-31 cm) that may represent the protolith for such fine-grained sheared intervals.

Deformed gabbroic rocks with type 3 and 4 textures commonly contain microscopic patches of fine-grained undeformed leucocratic material, with rectangular-shaped plagioclase, interstitial brown to green amphibole, occasional quartz, zircon, and apatite (Fig. 5B). These leucocratic segregations are similar to lithologies sampled at Site 735 (Dick et al., 1991) and interpreted there as the product of crystallization of trapped residual melt. Most leucocratic segregations do not contain clinopyroxene, either because it was never present, or because it has been replaced by brown to greenish brown amphibole. The origin, late magmatic or hydrothermal, of this amphibole is not clear. Sample 153-923A-2R-2, 30-33 cm, contains a few flakes of biotite that are bent but not recrystallized and line the contact between undeformed gabbro and extensively recrystallized gabbronorite (Table 3). The origin of this biotite is also unclear. Undeformed leucocratic segregations also fill intergranular interstices and fractures in some moderately deformed gabbroic rocks (Fig. 5C), producing a characteristic pattern of white seams in the rock (Fig. 2D). Coarser grained leucocratic segregations form centimeter-thick veins in deformed (Fig. 2D) and undeformed gabbros (e.g., Sample 153-921E-7R-2, 94-100 cm; Table 3).

The dynamically recrystallized assemblage in deformed gabbroic rocks with type 3 and 4 textures includes plagioclase, pyroxene, and olivine, as well as small amounts of brown amphibole (commonly $<1 \%$ ), titanium oxide and apatite. The brown amphibole, interpreted here as magmatic, is the only recrystallized hydrous phase in most samples. It occurs as polygonal or interstitial grains in the recrystallized aggregates (Figs. 5D, 5F). Brownish green to green amphiboles that fill microfractures or develop as hydrothermal alteration products of igneous and recrystallized minerals are most commonly unde- formed. One exception is a 1-cm-thick zircon-bearing shear zone in Sample 153-922B-4R-1, 67-74 cm (Table 3), that contains recrystallized green amphibole. Recrystallized clinopyroxene is present in all shear zones, except in noritic samples (Table 3). Recrystallized orthopyroxene is also common (Table 3). Olivine occurs as porphyroclasts and neoblasts rimmed with small polygonal orthopyroxene grains (Fig. 5F). Rims of undeformed orthopyroxene around olivine grains occur as an igneous texture in the MARK area gabbroic core, possibly reflecting late magmatic interactions between the olivine gabbro and a residual melt comparatively enriched in silica and/or water. Less commonly, olivine is rimmed by complex intergrowths of iron oxide and orthopyroxene. This last texture is clearly reactional and occurs in olivine-bearing gabbros that have been injected by late magmatic leucocratic segregates (e.g., Sample 153-921E-3R-1, 25$30 \mathrm{~cm}$ ). Polygonal orthopyroxene grains that surround olivine in sheared olivine gabbros (Fig. 5F) could be produced by the recrystallization of rims of late magmatic orthopyroxene, or by synkinematic reaction between the deforming olivine-bearing gabbro and a silicaand/or water-rich fluid.

\section{DUCTILE SHEAR ZONES: COMPOSITION OF IGNEOUS AND RECRYSTALLIZED MINERALS}

Microprobe analyses were performed using the CAMEBAX "Camparis" probe (Université de Paris VI), with a beam current of 40 $\mathrm{nA}$, a voltage of $15 \mathrm{~V}$, counting times of 10 to $20 \mathrm{~s}$, and a defocused beam for plagioclase analyses. Selected analyses are presented in Tables 4 through 6 .

\section{Compositional Trends in Igneous Clinopyroxene and Plagioclase}

Undeformed and weakly deformed (textural types 0 and 1) gabbroic rocks cored at Sites 921-923 show a wide range of igneous mineral compositions, comparable to the range measured in gabbroic rocks from the Southwest Indian Ocean (Fig. 6). This wide range of mineral compositions is consistent with the wide range of recovered gabbroic lithologies, and suggests extensive differentiation along a tholeiitic trend. Troctolites contain the most magnesium-rich clinopyroxenes and the most An-rich plagioclase and would be the first crystallization products along this trend. Leucocratic segregations plot at the other end of the compositional spectrum, with low plagioclase An contents, and clinopyroxene that, when present, has $\mathrm{Mg} \#$ values $\left(\mathrm{Mg} /\left[\mathrm{Mg}+\mathrm{Fe}_{\text {tot }}\right]\right)$ as low as 0.64 (Fig. 6).

Most deformed (textural types 2,3, and 4) gabbroic rocks cored at Sites 921-923 also plot on the clinopyroxene Mg\# vs. An\% plagioclase tholeiitic differentiation trend (Fig. 6). They have a more restricted range of compositions than undeformed or weakly deformed samples because the most-evolved igneous assemblages (leucocratic segregations) are never deformed and the least-evolved igneous assemblages (troctolites) are rarely deformed (Table 2 ). The deformed troctolites selected for this study (Samples 153-922A-2R-2, 106-111 $\mathrm{cm}$, and 153-922B-1W-1, 109-115 cm; Table 3) do not contain clinopyroxene, but they contain plagioclase with An contents up to $80 \%$.

Compositional trends in igneous clinopyroxene and plagioclase from samples listed in Table 3 are shown in Figures 7 and 8. These compositional trends are consistent with trends of increasing magmatic differentiation and very similar to trends measured in gabbroic core from Site 735 in the Southwest Indian Ridge (Bloomer et al., 1991; Ozawa et al., 1991).

Clinopyroxene in the least-evolved, undeformed to weakly deformed troctolites and olivine gabbros has variable titanium (up to $1.6 \%$ ) and aluminum contents (Fig. 7). The igneous clinopyroxene analyzed in the extensively recrystallized (textural type 4) gab- 
Table 2. Igneous lithology and textural type in gabbroic rocks from Sites 921 to 923.

\begin{tabular}{|c|c|c|c|c|c|c|c|c|c|c|c|c|c|c|}
\hline \multirow[b]{2}{*}{ Textural type: } & \multicolumn{2}{|c|}{0} & \multicolumn{2}{|c|}{1} & \multicolumn{2}{|c|}{2} & \multicolumn{2}{|c|}{3} & \multicolumn{2}{|c|}{4} & \multicolumn{2}{|c|}{ Total } & \multicolumn{2}{|c|}{ Subset } \\
\hline & A & $\mathrm{B}(\%)$ & A & $\mathrm{B}(\%)$ & A & $\mathrm{B}(\%)$ & A & $\mathrm{B}(\%)$ & A & $\mathrm{B}(\%)$ & A & $\mathrm{C}(\%)$ & A & $\mathrm{C}(\%)$ \\
\hline Troctolite & 25 & 43.1 & 26 & 44.8 & 3 & 5.2 & 3 & 5.2 & 1 & 1.7 & 58 & 18.4 & 30 & 22.7 \\
\hline Ol gabbro & 36 & 28.1 & 30 & 23.4 & 39 & 30.4 & 18 & 14.1 & 5 & 3.9 & 128 & 40.6 & 55 & 41.7 \\
\hline Gabbro & 15 & 23.8 & 15 & 23.8 & 21 & 33.3 & 7 & 11.1 & 5 & 7.9 & 63 & 20.0 & 28 & 21.2 \\
\hline Gabbronorite & 2 & 3.9 & 9 & 17.6 & 5 & 9.8 & 17 & 33.3 & 18 & 35.3 & 51 & 16.2 & 14 & 10.6 \\
\hline Leuc. segreg. & 15 & 100 & 0 & 0 & 0 & 0 & 0 & 0 & 0 & 0 & 15 & 4.7 & 5 & 3.8 \\
\hline Total & 93 & 29.5 & 80 & 25.4 & 68 & 21.6 & 45 & 14.3 & 29 & 9.2 & 315 & & & \\
\hline Subset & 59 & 44.7 & 33 & 25.0 & 29 & 21.9 & 10 & 7.6 & 1 & 0.7 & & & 132 & \\
\hline
\end{tabular}

Notes: Textural type corresponds to degree of recrystallization of plagioclase (see text). Data are from 315 gabbroic samples from Sites 921 to 923 , and a subset of 132 samples used for shipboard thin sections (Cannat, Karson, Miller, et al., 1995). Column A lists the number of samples in each textural type; column B lists the percentage of samples in each textual type; column C lists the percentage of samples of each lithology in the set of samples analyzed. Gabbronorite is used as a general term that includes gabbronorites, oxide gabbronorite, olivine gabbronorites, and norites. $\mathrm{Ol}=$ olivine, Leuc, segreg. = leucocratic segregation.

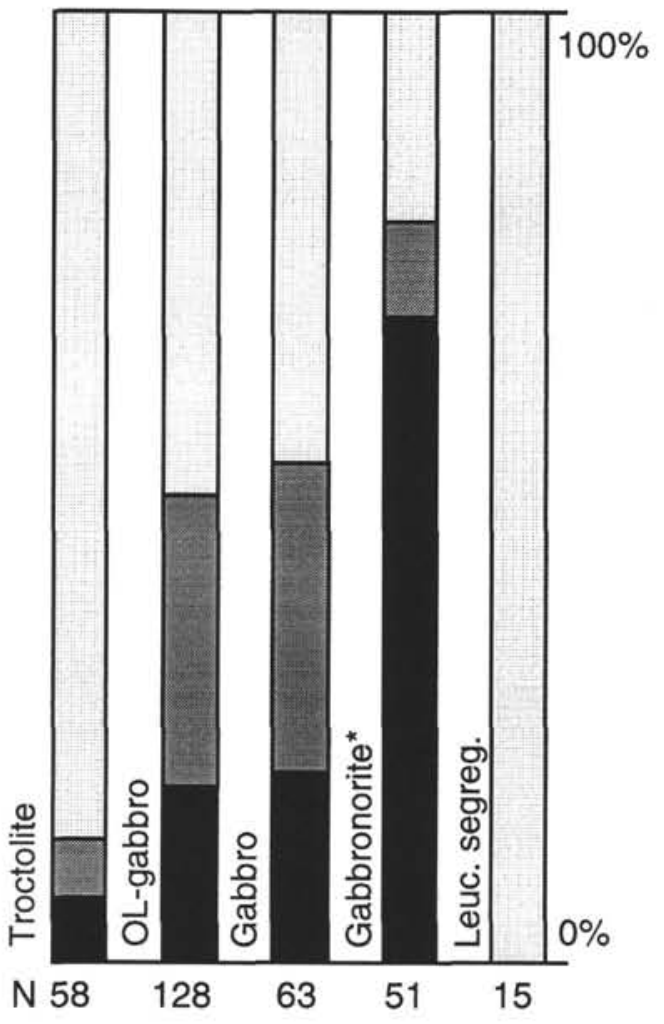

Figure 3. Histogram showing the proportion of recrystallized plagioclase in the different gabbroic lithologies sampled at Sites 921-923. Gabbronorites* = gabbronorites, oxide gabbronorites, olivine gabbronorites, and norites. $\mathrm{N}=$ numbers of samples of each lithology (see Table 2). Leuc. segreg. = leucocratic segregation. Light gray: less than $30 \%$ of plagioclase is recrystallized (textural types 0 and 1); dark gray: $30 \%-70 \%$ (textural type 2); black: $>70 \%$ (textural types 3 and 4).

bronoritic interval in Sample 153-922A-2R-2, 56-62 cm (Table 3), has less titanium (about $0.4 \%$ ), sodium, and chromium for a similarly high Mg\# (Table 4). This gabbronoritic interval also contains igneous plagioclase with relatively low An contents and therefore plots well above the tholeiitic differentiation trend in Figure 6. In clinopyroxenes with $\mathrm{Mg} \#$ lower than about 0.82 , titanium content first increases with decreasing $\mathrm{Mg}$ \#, up to $1 \%$ for $\mathrm{Mg} \#$ values of about 0.74 (Fig. 7), then decreases markedly, reaching values of less than $0.5 \%$ in some gabbronoritic samples and in the leucocratic segregation of Sample 153-923A-2R-6, 18-25 cm, and of less than $0.25 \%$ in leucocratic segregations of Samples 153-921E-7R1, 25-29 cm, and 153923A-16R-4, 85-89 cm (Table 3). These titanium-poor clinopyroxenes also have low aluminum contents (Fig. 7). In some gab- bronoritic samples, they coexist with clinopyroxenes that have similar Mg\#, but higher titanium and aluminum contents (e.g., Samples 153-921E-3R-1, 3-9 cm, and 153-921B-3R-1, 134-137 cm).

Potassium content in plagioclase (Fig. 8) increases slowly with decreasing anorthite contents, reaching values of about $0.3 \% \mathrm{~K}_{2} \mathrm{O}$ in most plagioclase from leucocratic segregations. Quartz-bearing segregations also contain small amounts of sodium-rich plagioclase with up to $0.82 \% \mathrm{~K}_{2} \mathrm{O}$. Igneous plagioclase in the strongly deformed, orthopyroxene-bearing intervals of Samples 153-922A-3R-1, 63-66 $\mathrm{cm}$, and 153-922B-1W-1, 109-115 cm, have high An contents (up to $80 \%$; Table 3). The strongly deformed interval in Sample 153-922B$1 \mathrm{~W}-1,109-115 \mathrm{~cm}$, is troctolitic and contains no relics of igneous clinopyroxene. The deformed gabbronorite in Sample 153-922A-3R-1, $63-66 \mathrm{~cm}$, contains clinopyroxene with low $\mathrm{Mg} \#$, and therefore plots well below the tholeiitic differentiation trend in Figure 6.

\section{Composition of Recrystallized Minerals}

Igneous and recrystallized plagioclase have similar average An contents in most samples (Table 5; Fig. 9A). The four samples (Samples 153-921E-3R-1, 3-9 cm, 153-921E-7R-2, 70-75 cm, 153922A-2R-6, 18-25 cm, and 153-922A-3R-1, 63-66 cm) that contain recrystallized plagioclase that is, on average, enriched in sodium compared with igneous grains also plot off the tholeiitic differentiation trend, toward higher An contents, or lower Mg\#, in Figure 6, a diagram of igneous clinopyroxene $\mathrm{Mg \#}$ vs. igneous plagioclase An content. In these four samples, the range of An contents in recrystallized plagioclase is large (Table 3; Fig. 9A).

Igneous and recrystallized clinopyroxene (Table 4; Fig. 9B) and olivine (Table 6) are compositionally similar in all samples. Values of $\mathrm{Mg \#}$ in igneous orthopyroxene from some deformed gabbronoritic samples vary over a wide range (Table 3 ). The range of $\mathrm{Mg} \#$ values is similar or smaller in recrystallized orthopyroxenes. These samples plot off the 1:1 trend in Figure 9C: average values of $\mathrm{Mg}$ \# in orthopyroxene neoblasts are either higher (Samples 153-921E-2R-2, 54$60 \mathrm{~cm}, 153-922 \mathrm{~A}-3 \mathrm{R}-1,3-9 \mathrm{~cm}$, and 153-922B-1W-1, 109-115 cm), or lower (Sample 153-921E-7R-2, 70-75 cm), than in igneous orthopyroxene. Two of these samples (Samples 153-921E-7R-2, 70-75 $\mathrm{cm}$, and 153-922A-3R-1, 3-9 cm) also plot off the tholeiitic differentiation trend in Figure 6. In other deformed samples, igneous and recrystallized orthopyroxenes are compositionally similar (Table 6; Fig. 9C).

Brown amphiboles that form interstitial grains and polygonal neoblasts in dynamically recrystallized samples (Figs. 5D, 5F) are titanium-rich hornblendes and less common pargasitic hornblendes (Fig. 10). They are compositionally similar to brown amphiboles that we interpret as magmatic, and that form small inclusions in igneous clinopyroxene, or rims around olivine and pyroxene crystals in undeformed gabbros. Variations in magnesium, chromium, and titanium contents in these brown amphiboles (Fig. 10) reflect the composition of igneous clinopyroxenes in each studied sample (Fig. 7). Pale 
Sample 153-922A-2R-5, 56-115cm

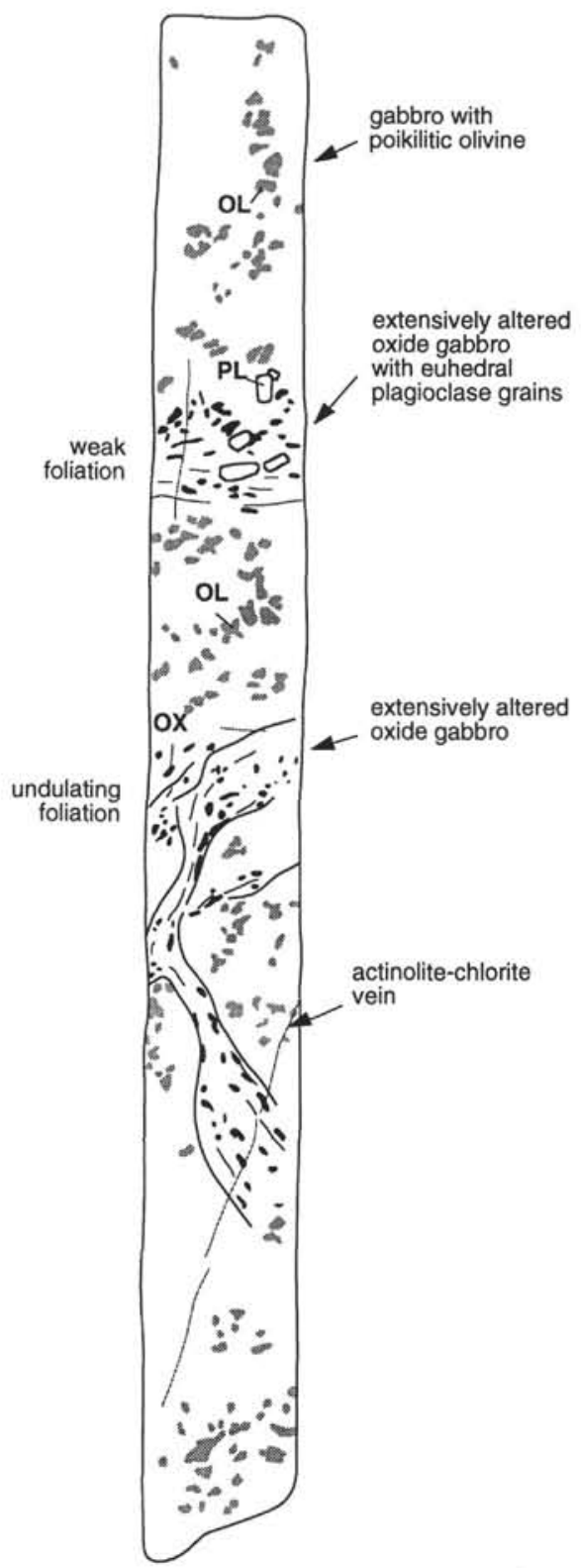

Figure 4. Sketch of the relationships between undeformed olivine gabbro and poikilitic olivine, and foliated to undeformed seams of oxide gabbronorite and norite in Sample 153-922A-2R-5, 56-115 cm. The orientation of the foliation in oxide-bearing intervals is controlled by the geometry of their contacts with the undeformed olivine gabbro. Core is $5.5 \mathrm{~cm}$ in diameter. OL $=$ olivine, $\mathrm{PL}=$ plagioclase, $\mathrm{OX}=\mathrm{Fe}$-Ti oxide.

brown to green actinolite and actinolitic hornblende (Fig. 10) crystallized as interstitial crystals in undeformed leucocratic segregations and as dynamically recrystallized grains in the zircon-bearing, $1-\mathrm{cm}$ thick shear zone of Sample 153-922B-4R-1, 67-74 cm (textural type 4; Table 3). Undeformed actinolitic amphiboles that occur in microfractures or as replacement for igneous minerals are not considered in this study because their crystallization postdated ductile deformation (with the exception of Sample 153-922B-4R-1, 67-74 cm). Selected microprobe analyses for these amphiboles are, however, listed in Table 6.

\section{A DISCUSSION OF MELT-ROCK CHEMICAL INTERACTIONS IN AND NEAR SHEAR ZONES}

Ductile shear zones at Sites 921-923 commonly developed in thin (millimeter- to decimeter-thick) gabbronoritic intervals, and have sharp contacts with less deformed to undeformed troctolites, olivine gabbros, or gabbros. Many of our sheared samples include one such contact (Table 3). Igneous minerals in deformed and less deformed lithologies near these contacts commonly have a wide range of compositions (e.g., Table 3). Average clinopyroxene and plagioclase compositions in some deformed samples plot off the tholeiitic differentiation trend, either toward higher plagioclase An contents or, in one case, toward higher clinopyroxene $\mathrm{Mg \#}$ values (Figs. 6, 11A). Average $\mathrm{Mg} \#$ values for igneous olivine do plot near the olivine/plagioclase differentiation trend (Fig. 11B), but the range of olivine $\mathrm{Mg} \#$ in deformed and less deformed lithologies is large (Table 3). Igneous orthopyroxene in deformed samples commonly plots off the orthopyroxene/plagioclase differentiation trend (Fig. 11C): igneous orthopyroxene $\mathrm{Mg \#}$ values are too low at a given plagioclase An content. In two of the four samples that contain a contact between two igneous orthopyroxene-bearing lithologies, we observe, however, that igneous orthopyroxene in the most deformed part of the sample has $\mathrm{Mg} \#$ values that are too high at a given plagioclase An content.

We interpret these chemical complexities as caused by melt-rock chemical interactions in and near the shear zones. In the following paragraphs, we use Samples 153-922A-2R-2, 56-62 cm, and 153$921 \mathrm{E}-7 \mathrm{R}-2,70-75 \mathrm{~cm}$, to discuss these chemical interactions.

The shear zone in Sample 153-922A-2R-2, 56-62 cm, contains sodium-rich plagioclase and occasional relics of fine-grained igneous clinopyroxene and orthopyroxene (Figs. 6, 11A, 11B) and is a 5-mmthick interval of mylonitic gabbronorite. The texture of this thin shear zone is similar to that shown in Figure 5D. This gabbronorite appears to have originally been a dikelet, cutting through an undeformed olivine gabbro (Table 3 ). The olivine gabbro contains high-magnesium olivine (Fig. 11B) and minor orthopyroxene that rims the olivine (Fig. 11C). Pyroxenes in the deformed gabbronorite also have high $\mathrm{Mg} \#$ values, but clinopyroxene chromium, aluminum, and titanium contents are much lower than in the olivine gabbro (Table 4). We propose that, in this sample, the Mg\# of the melt that crystallized the gabbronorite had been buffered by the magnesium-rich host gabbro.

In contrast, the shear zone in Sample 153-921E-7R-2, 70-75 cm (Fig. 5A), contains sodium-poor plagioclase porphyroclasts and ironrich igneous clinopyroxene (Figs. 6, 11A). It is a 3-cm-thick interval of mylonitic gabbronorite with angular to rounded xenocrysts of clinopyroxene, plagioclase, and olivine from the surrounding undeformed olivine gabbro (Fig. 5A). Igneous pyroxenes in the gabbronorite are fine-grained and commonly euhedral (Fig. 5E). Recrystallized plagioclase forms small polygonal to anhedral grains that surround ribbon-shaped debris of igneous porphyroclasts (Fig. 5E). There are also small tablet-shaped plagioclase grains (similar to those shown in Fig. 5C) that are associated with interstitial amphibole and zircon in thin leucocratic segregations.

In Figure 6, we have plotted the average An content (64.1\%) measured in ribbon-shaped plagioclase porphyroclasts in Sample 153921E-7R-2, 70-75 cm. An contents are much smaller in tabletshaped plagioclase from the leucocratic segregations $(24.6 \%$ on average; Table 3) and intermediate, with a large range of variation $(25.2 \%-53.2 \%)$ in recrystallized plagioclase (Fig. 9A). An contents in plagioclase cores from the undeformed olivine gabbro near the shear zone are also variable (68.2\%-76.1\%; Table 3), with a $69.1 \%$ average value. We propose that the ribbon-shaped plagioclase porphyroclasts in Sample 153-921E-7R-2, 70-75 cm, and, more generally, in shear zones that plot below the plagioclase/clinopyroxene differentiation trend in Figure 6 are in fact highly deformed plagioclase xenocrysts from the less-evolved surrounding gabbro. Plagioclase 
Table 3. Gabbroic samples microprobed for this study, with a summary of their mineral composition.

\begin{tabular}{|c|c|c|c|c|c|c|c|c|c|}
\hline \multirow[b]{3}{*}{$\begin{array}{l}\text { Core, section, } \\
\text { interval }(\mathrm{cm})\end{array}$} & \multirow{3}{*}{ Mineralogy } & \multirow[b]{3}{*}{$\begin{array}{l}\text { Text. } \\
\text { type }\end{array}$} & \multicolumn{7}{|c|}{ Average mineral composition } \\
\hline & & & PI & Cpx & Opx & Ol & $\mathrm{PI}(\mathrm{R})$ & Cpx (R) & Opx (R) \\
\hline & & & An\% & Mg\# & $\mathrm{Mg \#}$ & $\mathrm{Mg \#}$ & An\% & $\mathrm{Mg \#}$ & $\mathrm{Mg \#}$ \\
\hline 921B-3R-1, 33-36 & Gabbronorite, ox, am & 3 & 46.46 & 66.72 & 62.04 & & 45.41 & & \\
\hline \multirow{2}{*}{$921 \mathrm{~B}-3 \mathrm{R}-1,71-79$} & Ol gabbro, am, opx & 3 & 57.31 & 77.35 & 71.29 & 68.68 & 50.01 & 74.59 & \\
\hline & Gabbronorite, ox, am, ap & 3 & 45.74 & 67.51 & 59.16 & & 49.75 & 66.35 & 60.52 \\
\hline \multirow[t]{2}{*}{ 921B-3R-1, 94-99 } & Ol gabbro, am, opx & 2 & 48.71 & 75.24 & 67.49 & 63.76 & 49.99 & 74.23 & \\
\hline & Gabbronorite, zr & 3 & 38.15 & 67.1 & 69.57 & & 35.11 & 65.45 & \\
\hline $921 \mathrm{~B}-3 \mathrm{R}-1,134-137$ & Ol gabbro, am, opx & 0 & 54.89 & 77.18 & & 70.15 & 55.54 & 78.01 & 71.93 \\
\hline \multirow[t]{2}{*}{$921 \mathrm{C}-2 \mathrm{R}-1,70-78$} & Ol gabbro, am & 2 & 65.12 & 81.15 & & 73.89 & 65.17 & & \\
\hline & Ol gabbro, am, opx & 3 & 65.24 & 82.53 & & 77.01 & 65.75 & 85.41 & 79.29 \\
\hline $921 \mathrm{E}-1 \mathrm{R}-1,16-23$ & Ol gabbronorite, am, ox & 1 & 55.26 & 78.26 & 72.49 & 63.53 & & & \\
\hline \multirow[t]{2}{*}{$921 \mathrm{E}-2 \mathrm{R}-2,54-60$} & Ol gabbro, am & 1 & 56.05 & 80.29 & & 65.37 & & & \\
\hline & Gabbronorite, ox, ap, am & 4 & 38.59 & 65.78 & 53.88 & & 35.96 & & 59.18 \\
\hline $921 \mathrm{E}-2 \mathrm{R}-2,78-81$ & Ol gabbro, am, ox & 1 & 57.6 & 79.68 & & 65.62 & 56.74 & & \\
\hline 921E-3R-1, 3-9 & Gabbronorite, ox, am, ap & 3 & 58.18 & 66.22 & 62.06 & & 39.88 & 65.99 & 61.18 \\
\hline $921 \mathrm{E}-3 \mathrm{R}-1,25-30$ & Ol gabbro, opx, ox & 1 & 47.49 & 71.06 & 65.18 & 56.29 & 52.79 & & \\
\hline & Leuc. segr., qz & 0 & 26.56 & & & & & & \\
\hline 92 IE-3R-1, 37-41 & Gabbronorite, am & 3 & 42.03 & 64.67 & 56.57 & 38.5 & & 66.46 & \\
\hline & Gabbronorite, am, ox & 1 & 38.3 & 65.31 & 54.06 & 40.16 & & & \\
\hline & Leuc. segr. & 0 & 26.74 & & & & & & \\
\hline 921E-7R-1, 25-29 & Leuc. segr., qz, ap, zr & 0 & 28.67 & 64.42 & & & & & \\
\hline 921E-7R-2, 70-75 & Ol gabbro, poik. cpx, am & 0 & 69.08 & 85.17 & & 78.06 & & & \\
\hline & Gabbronorite, ox & 4 & 64.12 & 68.68 & 64.42 & & 31.1 & 67.69 & 60.96 \\
\hline & Leuc. segr., zr & 0 & 24.66 & & & & & & \\
\hline $921 \mathrm{E}-7 \mathrm{R}-2,94-100$ & Gabbro, poik. cpx & 0 & 65.23 & 84.87 & & & & & \\
\hline & Leuc, segr., qz, zr, sph & 0 & 28.58 & & & & & & \\
\hline $922 \mathrm{~A}-2 \mathrm{R}-2,56-62$ & Ol gabbro, poik. cpx, opx & 0 & 76.5 & 88.44 & 84.24 & 84.78 & & & \\
\hline & Gabbronorite myl, am & 4 & 45.46 & 86.05 & 82.25 & & 45.99 & 86.95 & \\
\hline $922 \mathrm{~A}-2 \mathrm{R}-2,106-119$ & Troctolite, am & 3 & 75.76 & & & 79.525 & 72.5 & & \\
\hline & Norite, ox, ap & 4 & 43.7 & & 62.515 & & 45.5 & & 64.84 \\
\hline $922 \mathrm{~A}-2 \mathrm{R}-2,123-128$ & Troctolite, poik. cpx, am & 0 & 76.19 & 86.19 & & & 83.13 & & \\
\hline & Gabbronorite myl, am & 4 & 45.88 & 75.28 & 69.03 & & 46.77 & 76.58 & 68.45 \\
\hline $922 \mathrm{~A}-2 \mathrm{R}-6,18-25$ & Troctolite, poik. cpx, opx, am & 1 & 69.6 & 86.92 & & 79.08 & 70.08 & & 83.66 \\
\hline & Gabbronorite, ox, am & 3 & 71.14 & 72.29 & 67.33 & & 58.9 & 77.36 & \\
\hline & Leuc. segr., ap, zr, am & 0 & 36.09 & 64.32 & & & & & \\
\hline $922 \mathrm{~A}-3 \mathrm{R}-1,63-66$ & Troctolite, poik. cpx, am, chr. & 1 & 77.38 & 87.42 & & 77.18 & 81.64 & & \\
\hline & Gabbronorite, ol, am, ox & 4 & 76.97 & 69.95 & 65.01 & 80.14 & 63.46 & & 71.05 \\
\hline $922 \mathrm{~B}-1 \mathrm{~W}-1,109-115$ & Ol gabbro, poik. cpx, am & 1 & 75.16 & 86.06 & & 75.75 & 74.07 & & \\
\hline & Troctolite, opx, am & 4 & 75.24 & & & 83.89 & 73.07 & & 78.15 \\
\hline & Gabbronorite, am, ox & 3 & 56.09 & 76.65 & 64.44 & & 57.82 & & 73.43 \\
\hline $922 \mathrm{~B}-4 \mathrm{R}-1,59-63$ & Altered gabbro, am & 1 & 68.52 & & & & & & \\
\hline & Altered, zr, am & 4 & & & & & 39.64 & & \\
\hline $922 \mathrm{~B}-4 \mathrm{R}-1,67-74$ & Gabbro, poik. cpx & 1 & 72.51 & 83.7 & & & & & \\
\hline & Gabbro, am, ap, zr & 4 & 39.95 & 68.34 & & & 33.97 & & \\
\hline & Leuc. segr., zr, am & 0 & 33.2 & & & & & & \\
\hline $923 \mathrm{~A}-2 \mathrm{R}-1,13-16$ & Gabbronorite, ox, am & 3 & 46.68 & 73 & 70.73 & & 48.32 & 75.11 & 68.32 \\
\hline & Ol microgabbro, am & 3 & 52.04 & 75.5 & & 65.65 & & & \\
\hline $923 \mathrm{~A}-2 \mathrm{R}-2,30-33$ & Gabbro, ox, am, ol, opx & 0 & 49.085 & 73.65 & & 61.72 & 48.91 & 66.59 & \\
\hline & Gabbronorite, ox & 3 & 47.32 & 67.12 & 65.63 & & 46.67 & & \\
\hline & Gabbronorite, ox, am, ol, biot. & 4 & & 75.79 & 68.23 & & 57.28 & 75.24 & 67.65 \\
\hline $923 \mathrm{~A}-3 \mathrm{R}-2,51-57$ & Gabbro & 2 & 56.41 & 73.54 & & & 54.28 & & \\
\hline & Norite, ox, am, ap & 4 & & & 65.51 & & 48.62 & & \\
\hline & Leuc. segr., ap, ox, am & 0 & 46.09 & & & & & & \\
\hline $923 \mathrm{~A}-8 \mathrm{R}-1,31-46$ & Troctolite & 0 & 71.39 & 81.61 & & 75.18 & & & \\
\hline & Microgabbro & 0 & 70.75 & 80.26 & & & & & \\
\hline & Gabbro & 0 & 60.16 & 80.2 & & & & & \\
\hline $923 \mathrm{~A}-11 \mathrm{R}-1,95-101$ & Ol gabbro, am & 2 & 57.41 & 76.515 & & 67.92 & & & \\
\hline & Gabbronorite & 4 & & 76.26 & 71.91 & & 55.34 & & 72.05 \\
\hline $923 \mathrm{~A}-12 \mathrm{R}-2,26-31$ & Ol gabbro, am, opx & 0 & 58.42 & 81.57 & 75.26 & 74.66 & & & \\
\hline & Microgabbronorite, am, ox & 1 & 56.11 & 78.11 & 73.83 & & & & \\
\hline $923 \mathrm{~A}-13 \mathrm{R}-1,124-128$ & Ol gabbro, poik. cpx, opx, am & 2 & 64.31 & 80.73 & 76.46 & 69.52 & 58.43 & & \\
\hline & Gabbronorite, am & 4 & & & 69.09 & & 55.14 & 75.29 & 69.38 \\
\hline $923 \mathrm{~A}-13 \mathrm{R}-1,136-142$ & Gabbronorite, ox, am & 3 & 62.28 & 78.32 & 71.72 & & 54.52 & 76.97 & 70.31 \\
\hline & Gabbro, opx, ol, am & 4 & & 76.41 & & 68.62 & 57.11 & 77.33 & 73.91 \\
\hline $923 \mathrm{~A}-15 \mathrm{R}-2,0-6$ & Ol gabbro, poik. cpx, am & 1 & 60.58 & 75.32 & & 68.03 & & & \\
\hline & Gabbro, ox, am, ap & 4 & & 73.57 & & & 47.76 & & \\
\hline $923 \mathrm{~A}-16 \mathrm{R}-4,6-12$ & Gabbro, poik. cpx, am & 0 & 50.88 & 69.94 & & & & & \\
\hline & Gabbro & 3 & 39.51 & 69.58 & & & 48.44 & 73.61 & \\
\hline & Leuc. segr., ap, sph, am & 0 & 22.99 & & & & & & \\
\hline $923 \mathrm{~A}-16 \mathrm{R}-4,85-89$ & Ol gabbro & 2 & 56.74 & 78.11 & & 66.08 & 54.95 & & \\
\hline & Leuc. segr., qz, ap, zr, am, ox & 0 & 18.73 & 66.86 & & & & & \\
\hline
\end{tabular}

Notes: See Tables 4, 5, and 6 for selected analyses. Text. type = textural type; $\mathrm{Pl}=$ plagioclase; $\mathrm{Cpx}=$ clinopyroxene; Opx = orthopyroxene; Ol = olivine; $\mathrm{Ol}$ gabbro = olivine gabbro; Leuc. segr. = leucocratic segregation; $\mathrm{myl}=$ mylonite; poik. $\mathrm{cpx}=$ poikilitic clinopyroxene; $\mathrm{ox}=$ iron titanium oxide; $\mathrm{am}=\mathrm{amphibole} ; \mathrm{zr}=\mathrm{zircon} ; \mathrm{ap}=\mathrm{apatite} ; \mathrm{qz}=\mathrm{quartz} ;$ chr. = ferrichromite; biot. = biotite; $\mathrm{sph}=$ sphene; $(\mathrm{R})=$ recrystallized.

that crystallized from the gabbronoritic parent melt would subsequently have been $100 \%$ recrystallized. In order to plot near the tholeiitic differentiation trend of Figure 6, this plagioclase should have had An contents between $35 \%$ and $50 \%$. The most sodium-rich neoblasts have significantly lower An contents, similar to An contents in tablet-shaped plagioclase from the leucocratic segregations. We propose that this results from interactions between the deforming gabbronorite and patches of sodium- and silica-rich residual melt that later crystallized the leucocratic segregations. These interactions could have involved subsolidus reequilibration of plagioclase neoblasts and porphyroclasts with the melt patches and also crystallization of progressively less anorthitic igneous plagioclase from these melt patches before the end of ductile deformation.

Orthopyroxene in the gabbronorite in Sample 153-921E-7R-2, $70-75 \mathrm{~cm}$, occurs as small euhedral grains (Fig. 5E), as even smaller and anhedral grains near olivine xenocrysts, and as polygonal neo- 
A
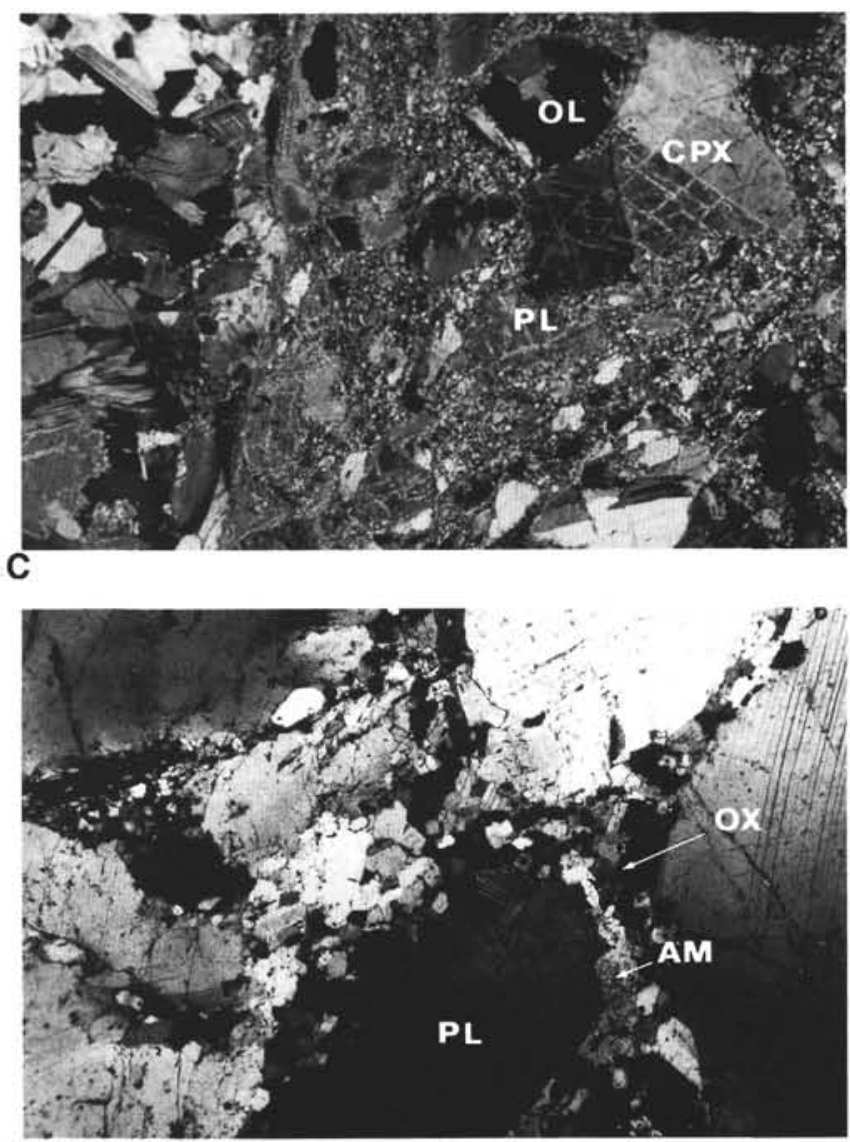

E

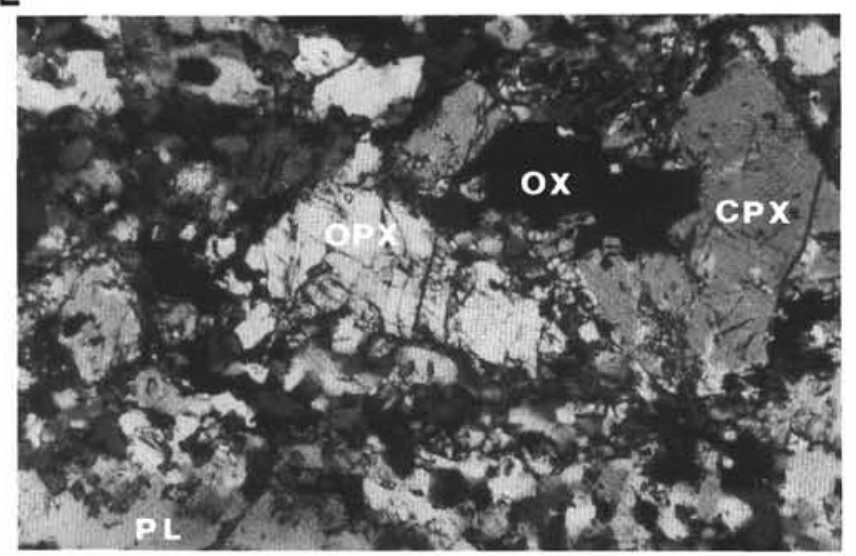

B
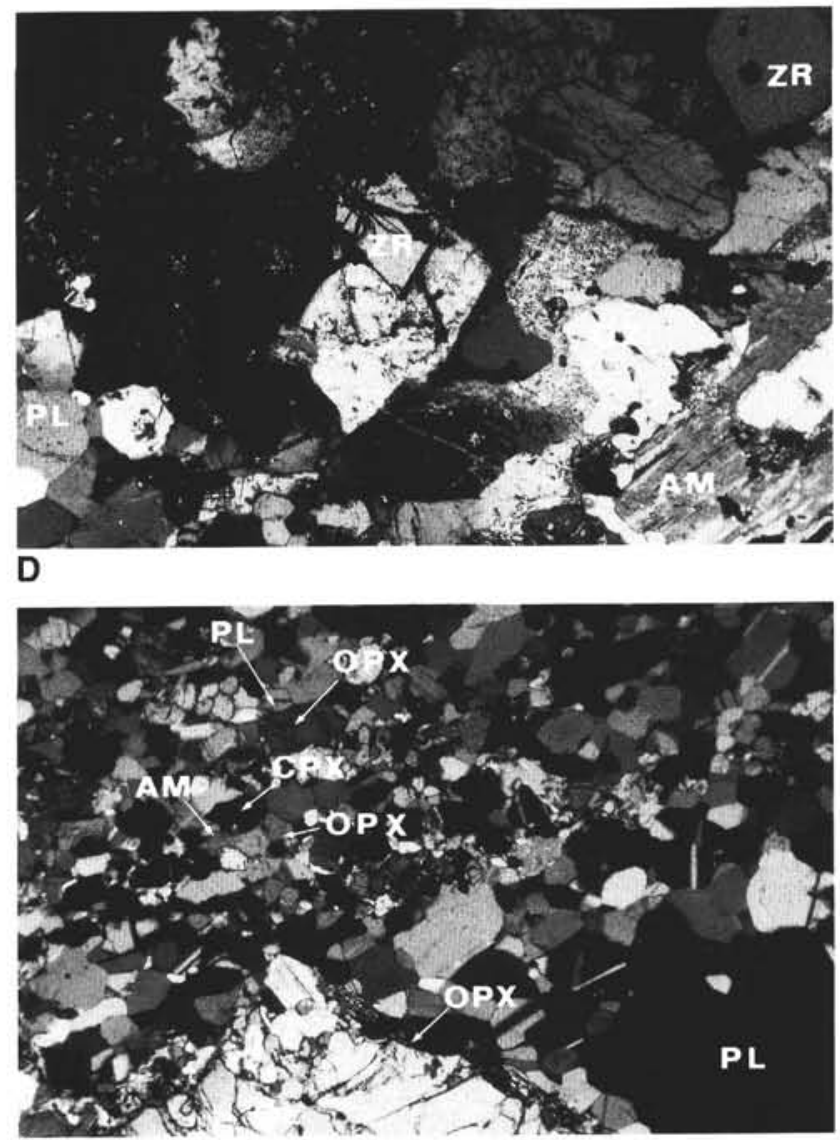

$\mathbf{F}$

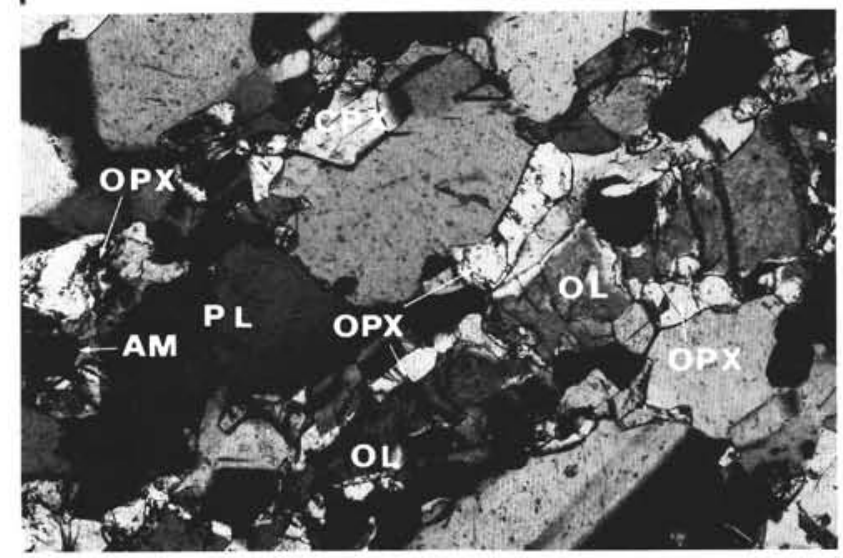

Figure 5. Photomicrographs (crossed nicols). Abbreviations as in Table 3. A. Sample 153-921E-7R-2, 70-75 cm. Mylonitic gabbronorite in medium-grained, undeformed olivine gabbro. This shear zone is fan-shaped and very fine-grained. It contains olivine, plagioclase, and clinopyroxene xenocrysts of the undeformed gabbro host. Length of view is $2.4 \mathrm{~cm}$. B. Sample 153-923A-16R-4, 85-89 cm. Tablet-shaped plagioclase, euhedral zircon, and interstitial quartz form undeformed leucocratic segregation in deformed olivine gabbro (polygonal recrystallized plagioclase visible in lower left corner). Length of view is $3.2 \mathrm{~mm}$. C. Sample 153-921E-3R-1, 25-30 cm. Plagioclase-rich domain in moderately deformed olivine gabbro. Plagioclase porphyroclasts are rimmed by fine-grained, polygonal, plagioclase neoblasts and also by undeformed rectangular-to-square, small, plagioclase grains that form leucocratic segregations with minor interstitial amphibole and oxides. Length of view is $3.2 \mathrm{~mm}$. D. Sample 153-923A-13R-1, 124-128 cm. Contact between weakly deformed olivine gabbro and an extensively recrystallized gabbronorite with oval-shaped pyroxenes, and aggregates of polygonal plagioclase, pyroxene, and minor brown amphibole neoblasts (core photograph in Fig. 2C). Length of view is $3.2 \mathrm{~mm}$. E. Sample 153-921E-7R-2, 70-75 cm. Detail of mylonitic gabbronorite (see Fig. 5A) with a square igneous clinopyroxene, a rectangular igneous orthopyroxene, a grain of iron-titanium oxide in finely recrystallized plagioclase. Part of a ribbon-shaped plagioclase porphyroclast is visible in lower left corner. Length of view is $2 \mathrm{~mm}$. F. Sample 153-923A-13R-1, 136-142 cm. Foliated olivine gabbro in shear zone, pictured in Figure 2C, contains ribbon-shaped, partly recrystallized, olivine relics coated by polygonal grains of orthopyroxene. Recrystallized aggregate near olivine includes polygonal plagioclase, orthopyroxene, clinopyroxene, and minor brown amphibole. Length of view is $1.2 \mathrm{~mm}$. 
Table 4. Selected microprobe analyses of clinopyroxene in gabbroic rocks listed in Table 3.

\begin{tabular}{|c|c|c|c|c|c|c|c|c|c|c|c|c|c|c|c|c|c|c|}
\hline \multirow{3}{*}{$\begin{array}{l}\text { Sample no: } \\
\text { Text. type: }\end{array}$} & \multirow{3}{*}{$\begin{array}{c}\begin{array}{c}921 \mathrm{E}-7 \mathrm{R}-1, \\
25-29 \mathrm{~cm}\end{array} \\
0 \\
\mathrm{P}\end{array}$} & \multicolumn{3}{|c|}{$921 \mathrm{E}-2 \mathrm{R}-2,54-60 \mathrm{~cm}$} & \multicolumn{6}{|c|}{$921 \mathrm{E}-7 \mathrm{R}-2,70-75 \mathrm{~cm}$} & \multicolumn{3}{|c|}{$923 \mathrm{~A}-2 \mathrm{R}-1,13-16 \mathrm{~cm}$} & \multicolumn{2}{|c|}{$923 \mathrm{~A}-12 \mathrm{R}-2,26-31 \mathrm{~cm}$} & \multicolumn{3}{|c|}{$921 \mathrm{E}-3 \mathrm{R}-1,37-41 \mathrm{~cm}$} \\
\hline & & 1 & 1 & 4 & 0 & 0 & 4 & 4 & 4 & 4 & 3 & 3 & 3 & 0 & 0 & 2 & 2 & 1 \\
\hline & & $P$ & $P$ & $P$ & $P$ & P & P & $P$ & Prim & $\mathrm{R}$ & $P$ & $\mathbf{R}$ & P & Int. & P & P & $\mathrm{R}$ & $\mathrm{P}$ \\
\hline $\mathrm{Na}_{2} \mathrm{O}$ & 0.45 & 0.34 & 0.39 & 0.46 & 0.39 & 0.43 & 0.35 & 0.35 & 0.43 & 0.43 & 0.47 & 0.41 & 0.44 & 0.38 & 0.42 & 0.43 & 0.34 & 0.41 \\
\hline $\mathrm{Cr}_{2} \mathrm{O}_{3}$ & 0.02 & 0.09 & 0.14 & 0 & 1.08 & 0.8 & 0.98 & 0.86 & 0.08 & 0.02 & 0.02 & 0.09 & 0.12 & 0.11 & 0.03 & 0 & 0 & 0.01 \\
\hline $\mathrm{MgO}$ & 11.81 & 17.06 & 15.41 & 12.64 & 16.26 & 18.64 & 16.07 & 16.96 & 13.7 & 13.28 & 14.06 & 14.58 & 15.22 & 16.05 & 14.92 & 12.92 & 12.93 & 12.65 \\
\hline $\mathrm{Al}_{2} \mathrm{O}_{3}$ & 0.33 & 2.66 & 2.28 & 1.7 & 4.02 & 2.92 & 3.83 & 3.54 & 0.72 & 0.76 & 2.49 & 2.26 & 2.4 & 2.3 & 2.42 & 1.94 & 1.41 & 1.87 \\
\hline $\mathrm{SiO}_{2}$ & 52.85 & 52.56 & 51.77 & 51.27 & 51.39 & 52.69 & 51.38 & 51.78 & 52.74 & 52.34 & 50.98 & 51.46 & 51.73 & 52.13 & 51.51 & 51.7 & 52.25 & 51.9 \\
\hline $\mathrm{CaO}$ & 21.81 & 20.62 & 20.29 & 20.13 & 21.33 & 17.23 & 22.28 & 21.08 & 21.01 & 20.93 & 20.85 & 21.15 & 20.55 & 21.88 & 21.54 & 19 & 20.04 & 19.28 \\
\hline $\mathrm{TiO}_{2}$ & 0.09 & 0.58 & 0.58 & 0.64 & 0.44 & 0.33 & 0.45 & 0.41 & 0.19 & 0.22 & 1.03 & 0.6 & 0.85 & 0.75 & 1.08 & 0.52 & 0.37 & 0.62 \\
\hline $\mathrm{MnO}$ & 0.54 & 0.2 & 0.27 & 0.46 & 0.14 & 0.11 & 0.1 & 0.09 & 0.34 & 0.4 & 0.3 & 0.23 & 0.23 & 0.16 & 0.25 & 0.44 & 0.42 & 0.44 \\
\hline $\mathrm{FeO}$ & 11.85 & 5.84 & 8.38 & 12.77 & 4.33 & 6.67 & 3.71 & 4.4 & 10.49 & 11.3 & 9.24 & 8.62 & 7.97 & 5.83 & 7.5 & 12.79 & 11.57 & 11.8 \\
\hline $\mathrm{NiO}$ & 0.01 & 0.01 & 0 & 0.05 & 0.02 & 0.03 & 0.03 & 0.02 & 0.01 & 0.03 & 0.0 & 0.04 & 0 & 0 & 0.04 & 0.01 & 0.01 & 0.01 \\
\hline CalcTotal & 99.76 & 99.96 & 99.52 & 100.11 & 99.4 & 99.86 & 99.17 & 99.49 & 99.72 & 99.7 & 99.4 & 99.4 & 99.5 & 99.58 & 99.7 & 99.75 & 99.34 & 99.01 \\
\hline Mg\# & 63.985 & 83.887 & 76.626 & 63.832 & 86.996 & 83.28 & 88.538 & 87.295 & 69.954 & 67.697 & 73.056 & 75.108 & 77.285 & 83.065 & 78.01 & 64.299 & 66.57 & 65.657 \\
\hline
\end{tabular}

Notes: Text. type $=$ textural type; $\mathrm{P}=$ porphyroclast core; $\mathrm{Prim}=$ porphyroclast rim; $\mathrm{R}=$ recrystallized; Int. $=$ interstitial. Calc Total $=$ calculated total.

Table 4 (continued).

\begin{tabular}{|c|c|c|c|c|c|c|c|c|c|c|c|c|c|c|c|c|c|c|c|c|}
\hline \multirow{3}{*}{$\begin{array}{l}\text { Sample no: } \\
\text { Text. type: }\end{array}$} & \multicolumn{2}{|c|}{$921 \mathrm{E}-2 \mathrm{R}-2,78-81 \mathrm{~cm}$} & \multirow{2}{*}{$\begin{array}{l}\begin{array}{c}921 \mathrm{E}-3 \mathrm{R}-1, \\
25-30 \mathrm{~cm}\end{array} \\
1\end{array}$} & \multirow{2}{*}{$\begin{array}{c}\begin{array}{c}921 \mathrm{E}-1 \mathrm{R}-1, \\
16-23 \mathrm{~cm}\end{array} \\
1\end{array}$} & \multicolumn{5}{|c|}{$923 \mathrm{~A}-13 \mathrm{R}-1,124-128 \mathrm{~cm}$} & \multicolumn{6}{|c|}{$923 \mathrm{~A}-13 \mathrm{R}-1,136-142 \mathrm{~cm}$} & \multicolumn{5}{|c|}{$923 \mathrm{~A}-2 \mathrm{R}-2,30-33 \mathrm{~cm}$} \\
\hline & 1 & 1 & & & 2 & 2 & 2 & 4 & 4 & 3 & 3 & 3 & 4 & 4 & 4 & 1 & 1 & 4 & 4 & 2 \\
\hline & $P$ & $\mathrm{P}$ & $P$ & $P$ & $\mathrm{P}$ & $\mathbf{R}$ & $\mathbf{P}$ & R & $R$ & $P$ & $\mathrm{P}$ & $R$ & $\mathrm{P}$ & $\mathrm{R}$ & $R$ & $P$ & $P$ & $P$ & $R$ & $P$ \\
\hline $\mathrm{Na}_{2} \mathrm{O}$ & 0.42 & 0.31 & 0.48 & 0.38 & 0.45 & 0.39 & 0.36 & 0.41 & 0.41 & 0.4 & 0.39 & 0.42 & 0.43 & 0.39 & 0.4 & 0.42 & 0.45 & 0.42 & 0.39 & 0.46 \\
\hline $\mathrm{Cr}_{2} \mathrm{O}_{3}$ & 0.09 & 0.08 & 0.05 & 0.04 & 0.7 & 0.64 & 0.35 & 0.46 & 0.08 & 0.02 & 0.18 & 0.24 & 0.21 & 0.0 & 0.12 & 0.05 & 0.02 & 0.28 & 0.08 & 0.04 \\
\hline $\mathrm{MgO}$ & 14.72 & 15.97 & 14.54 & 14.62 & 14.77 & 15.41 & 16.4 & 14.95 & 14.45 & 15.74 & 16.17 & 14.92 & 14.85 & 14.83 & 15.16 & 14.46 & 14.19 & 14.81 & 14.64 & 14.35 \\
\hline $\mathrm{Al}_{2} \mathrm{O}_{3}$ & 2.67 & 2.28 & 2.9 & 2.62 & 3.67 & 3.68 & 2.97 & 2.48 & 2.02 & 2.4 & 2.95 & 2.83 & 2.61 & 2.08 & 2.12 & 2.44 & 2.26 & 2.7 & 2.21 & 2.5 \\
\hline $\mathrm{SiO}_{2}{ }^{\circ}$ & 52.25 & 52.55 & 51.96 & 51.65 & 51.57 & 52.91 & 52.75 & 52.9 & 53.13 & 51.56 & 52.43 & 51.82 & 52.06 & 52.6 & 52.42 & 52.14 & 52.09 & 52.55 & 51.85 & 51.16 \\
\hline $\mathrm{CaO}^{2}$ & 20.69 & 21.85 & 20.88 & 20.8 & 20.47 & 21.72 & 20.08 & 20.94 & 20.41 & 17.25 & 20.79 & 20.66 & 21.02 & 20.68 & 21.36 & 20.62 & 20.71 & 20.96 & 21.21 & 20.74 \\
\hline $\mathrm{TiO}_{2}$ & 0.96 & 0.56 & 0.98 & 0.72 & 0.63 & 0.5 & 0.65 & 0.55 & 0.59 & 0.96 & 0.54 & 0.88 & 0.85 & 0.67 & 0.64 & 0.76 & 0.77 & 0.96 & 0.62 & 0.87 \\
\hline $\mathrm{MnO}$ & & 0.12 & & 0.22 & 0.18 & 0.14 & 0.19 & 0.21 & 0.31 & 0.32 & 0.2 & 0.28 & 0.27 & 0.22 & 0.17 & 0.27 & 0.31 & 0.28 & 0.26 & 0.29 \\
\hline $\mathrm{FeO}$ & 8.53 & 6.05 & 8.05 & & 7.17 & 5.13 & 5. & 7.7 & 9.32 & 10.97 & 5.95 & 7.96 & 7.99 & 8.64 & 7.32 & 8.77 & 10.17 & 8.43 & 8.02 & 8.91 \\
\hline $\mathrm{NiO}$ & 0 & 0.01 & 0 & 0.01 & 0 & 0 & 0.06 & 0.03 & 0.05 & 0.000 & 0.000 & 0.000 & 0.04 & 0.04 & 0.02 & 0 & 0 & 0 & 0 & 0.01 \\
\hline CalcTotal & 100.59 & 99.78 & 100.03 & 98.43 & 99.6 & 100.53 & 99.71 & 100.63 & 100.78 & 99.63 & 99.61 & 100.01 & 100.34 & 100.21 & 99.74 & 99.91 & 100.96 & 101.38 & 99.29 & 99.35 \\
\hline Mg\# & 75.459 & 82.47 & 76.305 & 77.933 & 78.595 & 84.265 & 83.217 & 77.578 & 73.427 & 71.891 & 82.9 & 76.975 & 76.821 & 75.37 & 78.678 & 74.625 & 71.33 & 75.795 & 76.5 & 74.159 \\
\hline
\end{tabular}

Table 4 (continued).

\begin{tabular}{|c|c|c|c|c|c|c|c|c|c|c|c|c|c|c|c|c|c|}
\hline \multirow{3}{*}{$\begin{array}{l}\text { Sample no: } \\
\text { Text. type: }\end{array}$} & \multirow{3}{*}{$\begin{array}{c}\begin{array}{c}921 \mathrm{E}-7 \mathrm{R}-2, \\
94-100 \mathrm{~cm}\end{array} \\
0 \\
P\end{array}$} & \multicolumn{2}{|c|}{ 921E-3R-1, 3-9 cm } & \multicolumn{3}{|c|}{$923 \mathrm{~A}-16 \mathrm{R}-4,85-89 \mathrm{~cm}$} & \multicolumn{2}{|c|}{$923 \mathrm{~A}-11 \mathrm{R}-1,95-101 \mathrm{~cm}$} & \multicolumn{2}{|c|}{$923 \mathrm{~A}-3 \mathrm{R}-2,51-57 \mathrm{~cm}$} & \multicolumn{5}{|c|}{$923 \mathrm{~A}-8 \mathrm{R}-1,31-46 \mathrm{~cm}$} & \multicolumn{2}{|c|}{$923 \mathrm{~A}-15 \mathrm{R}-2,0-6 \mathrm{~cm}$} \\
\hline & & 3 & 3 & 2 & 2 & 0 & 2 & 4 & 2 & 2 & 0 & 0 & 0 & 0 & 0 & 1 & 4 \\
\hline & & $\mathrm{P}$ & $\mathbf{R}$ & $P$ & $\mathbf{P}$ & $\mathbf{P}$ & $\mathbf{P}$ & P & $\mathrm{P}$ & $P$ & $\mathrm{P}$ & $\mathrm{P}$ & $\mathrm{P}$ & $\mathbf{P}$ & $\mathrm{P}$ & $\mathrm{P}$ & $\mathrm{P}$ \\
\hline $\mathrm{Na}_{2} \mathrm{O}$ & 0.47 & 0.41 & 0.36 & 0.38 & 0.37 & 0.45 & 0.53 & 0.41 & 0.4 & 0.4 & 0.43 & 0.41 & 0.34 & 0.42 & 0.45 & 0.38 & 0.42 \\
\hline $\mathrm{Cr}_{2} \mathrm{O}_{3}$ & 0.37 & 0.02 & 0 & 0.09 & 0.11 & 0.01 & 0.05 & 0.08 & 0.06 & 0.04 & 0.16 & 0.17 & 0.12 & 0.05 & 0.11 & 0.36 & 0.08 \\
\hline $\mathrm{MgO}$ & 15.96 & 12.76 & 13.18 & 16.01 & 16.33 & 12.71 & 14.1 & $14.3^{\circ}$ & 15.07 & 14.23 & 15.39 & 15.92 & 16.48 & 15.1 & 15.22 & 14.47 & $\begin{array}{r}14.01 \\
14.01\end{array}$ \\
\hline $\mathrm{Al}_{2} \mathrm{O}_{3}$ & 2.42 & 1.83 & 1.44 & 2.48 & 2.88 & 0.62 & 2.78 & 2.62 & 2.08 & 2.43 & 3.1 & 3.45 & 3.01 & 2.84 & 3.22 & 3.58 & 1.58 \\
\hline $\begin{array}{l}\mathrm{AiO}_{2} \mathrm{O}_{3} \\
\mathrm{~S}_{2}\end{array}$ & 52.74 & 51.08 & 52.11 & 52.16 & 51.95 & 52.36 & 51.41 & $\begin{array}{r}51.62 \\
51.69\end{array}$ & 52.44 & 51.68 & 52.66 & 50.39 & 53.72 & 52.47 & 51.17 & 51.01 & 52.48 \\
\hline $\mathrm{CaO}$ & 21.72 & 18.95 & 19.34 & $\begin{array}{l}52.10 \\
19.14\end{array}$ & 20.09 & 20.55 & $\begin{array}{l}31.01 \\
21.02\end{array}$ & 21.48 & 20.61 & 19.98 & 21.68 & 20.25 & 20.24 & $\begin{array}{l}21.49 \\
21.39\end{array}$ & 22.19 & 20.51 & 20.87 \\
\hline $\mathrm{TiO}_{2}$ & $\begin{array}{r}0.69 \\
\end{array}$ & 0.63 & 0.38 & 0.81 & 0.6 & 0.18 & 1.01 & 0.77 & 0.55 & 0.73 & 1.06 & 1.12 & 0.7 & 1.04 & 1.2 & $\begin{array}{r}20.61 \\
0.69\end{array}$ & 0.45 \\
\hline $\mathrm{MnO}$ & 0 & 0.42 & 0.43 & 0.22 & 0.23 & 0.46 & 0 & 0.26 & 0.23 & 0.31 & 0.14 & 0.2 & 0.19 & 0.22 & 0.19 & 0.21 & 0.25 \\
\hline $\mathrm{FeO}$ & 4.86 & $\begin{array}{r}0.42 \\
13.13\end{array}$ & $\begin{array}{l}0.43 \\
12.1\end{array}$ & 8.67 & 6.36 & 11.9 & 8.49 & 7.84 & 8.11 & 9.97 & 5.84 & 7.03 & 6.45 & 7.2 & 6.11 & 8.11 & 9.74 \\
\hline $\mathrm{NiO}$ & 0.01 & 0 & 0.01 & 0.07 & 0.03 & 0.02 & 0.02 & 0 & 0 & 0.02 & 0.01 & 0.02 & 0.07 & 0.01 & 0.05 & 0.02 & 0 \\
\hline CalcTotal & 99.42 & 99.24 & 99.37 & 100.04 & 98.95 & 99.28 & 99.41 & 99.47 & 99.55 & 99.78 & 100.46 & 98.96 & 101.33 & 100.74 & 99.91 & 99.36 & 99.89 \\
\hline $\mathrm{Mg} \#$ & 85.406 & 63.412 & 66.021 & 76.7 & 82.062 & 65.559 & 74.752 & 76.48 & 76.81 & 71.78 & 82.45 & 80.138 & 81.997 & 78.884 & 81.615 & 76.097 & 71.945 \\
\hline
\end{tabular}




\begin{tabular}{|c|c|c|c|c|c|c|c|c|c|c|c|c|c|c|c|c|c|c|}
\hline \multicolumn{3}{|c|}{ Sample no: $923 \mathrm{~A}-16 \mathrm{R}-4,6-12 \mathrm{~cm}$} & \multicolumn{6}{|c|}{$922 \mathrm{~A}-2 \mathrm{R}-6,18-25 \mathrm{~cm}$} & \multicolumn{2}{|c|}{$922 \mathrm{~A}-3 \mathrm{R}-1,63-66 \mathrm{~cm}$} & \multicolumn{2}{|c|}{$922 \mathrm{~B}-4 \mathrm{R}-1,67-74 \mathrm{~cm}$} & \multicolumn{3}{|c|}{$922 \mathrm{~A}-2 \mathrm{R}-2,123-128 \mathrm{~cm}$} & \multicolumn{3}{|c|}{$922 \mathrm{~A}-2 \mathrm{R}-2,56-62 \mathrm{~cm}$} \\
\hline Text. type: & 0 & 3 & 1 & 3 & 3 & 0 & 3 & 1 & 4 & 1 & 1 & 4 & 4 & 4 & 0 & 4 & 4 & 0 \\
\hline & $\mathrm{P}$ & $P$ & $\mathrm{P}$ & $\mathrm{P}$ & $\mathrm{R}$ & $\mathrm{P}$ & $\mathrm{P}$ & $\mathbf{P}$ & $\mathrm{P}$ & $\mathrm{P}$ & $\mathrm{P}$ & $\mathrm{P}$ & $\mathrm{P}$ & $\mathrm{R}$ & $\mathrm{P}$ & $\mathrm{R}$ & $\mathrm{P}$ & $\mathrm{P}$ \\
\hline $\mathrm{Na}_{2} \mathrm{O}$ & 0.44 & 0.49 & 0.43 & 0.4 & 0.31 & 0. & 0.35 & 0.3 & 0.4 & 0.67 & 0.57 & 0.42 & 0.41 & 0.37 & 0.4 & 0.31 & 0.35 & 0.49 \\
\hline $\mathrm{Cr}_{2} \mathrm{O}_{3}$ & 0.08 & 0.04 & 0.15 & 0.47 & 0.17 & 0.000 & 0.02 & 1.01 & 0.01 & 0.39 & 0.05 & 0.02 & 0.07 & 0.03 & 0.38 & 0.04 & 0.06 & 0.46 \\
\hline $\mathrm{MgO}$ & 13.47 & 13.06 & 13.8 & 13.44 & 14.69 & 12.83 & 13.78 & 17.87 & 14.21 & 16.64 & 15.66 & 13.49 & 14.62 & 14.8 & 15.97 & 16.54 & 16.53 & 16.15 \\
\hline $\mathrm{Al}_{2} \mathrm{O}_{3}$ & 2.18 & 2.09 & 2.49 & 2.44 & 1.000 & 1.64 & 1.43 & 3.19 & 1.5 & 3.39 & 3.33 & 1.05 & 1.95 & 1.35 & 2.95 & 1.26 & 1.39 & 3.41 \\
\hline $\mathrm{SiO}_{2}$ & 50.85 & 50.54 & 51.6 & 51.76 & 53.24 & 51.73 & 52.5 & 52.75 & 51.66 & 50.85 & 52.3 & 52.84 & 51.79 & 52.67 & 51.57 & 53.19 & 52.63 & 50.91 \\
\hline $\mathrm{CaO}^{2}$ & 20.97 & 20.58 & 20.93 & 21.45 & 21.49 & 19.39 & 20.15 & 20.23 & 20.52 & 21.52 & 21.34 & 20.26 & 19.93 & 21.88 & 22.77 & 22.77 & 22.17 & 21.9 \\
\hline $\mathrm{TiO}_{2}$ & 0.74 & 0.74 & 0.78 & 0.65 & 0.24 & 0.54 & 0.41 & 0.41 & 0.53 & 1.31 & 1.01 & 0.29 & 0.74 & 0.41 & 1.23 & 0.59 & 0.64 & 1.49 \\
\hline $\mathrm{MnO}$ & 0.36 & 0.39 & 0.32 & 0.34 & 0.37 & 0.48 & 0.31 & 0.12 & 0.43 & 0.11 & 0.19 & 0.52 & 0.3 & 0.3 & 0.16 & 0.12 & 0.16 & 0.15 \\
\hline $\mathrm{FeO}$ & 10.02 & 10.59 & 9.16 & 8.93 & 8.32 & 12.69 & 10.7 & 4.19 & 10.23 & 3.71 & 5.43 & 11.48 & 9.23 & 8.07 & 4.12 & 4.43 & 4.78 & 3.88 \\
\hline $\mathrm{NiO}$ & 0.02 & 0 & 0.000 & 0.000 & 0.02 & 0.01 & 0.03 & 0.02 & 0.03 & 0 & 0.05 & 0.03 & 0.07 & 0.01 & 0.04 & 0.02 & 0.06 & 0.06 \\
\hline CalcTotal & 99.14 & 98.5 & 99.68 & 99.9 & 99.85 & 99.71 & 99.68 & 100.09 & 99.53 & 98.59 & 99.93 & 100.39 & 99.12 & 99.89 & 99.59 & 99.28 & 98.77 & 98.88 \\
\hline Mg\# & 70.571 & 68.738 & 72.869 & 72.839 & 75.879 & 64.322 & 69.655 & 88.374 & 71.219 & 88.887 & 83.706 & 67.692 & 73.848 & 76.578 & 87.364 & 86.953 & 86.05 & 88.123 \\
\hline
\end{tabular}

Table 4 (continued).

\begin{tabular}{|c|c|c|c|c|c|c|c|c|c|c|c|c|c|c|c|c|c|}
\hline \multirow{3}{*}{$\begin{array}{l}\text { Sample no: } \\
\text { Text. type: }\end{array}$} & \multirow{2}{*}{$\begin{array}{c}\begin{array}{c}921 \mathrm{~B}-3 \mathrm{R}-1, \\
33-36 \mathrm{~cm}\end{array} \\
3\end{array}$} & \multicolumn{3}{|c|}{$921 \mathrm{~B}-3 \mathrm{R}-1,94-99 \mathrm{~cm}$} & \multicolumn{3}{|c|}{$922 \mathrm{~B}-1 \mathrm{~W}-1,109-115 \mathrm{~cm}$} & \multicolumn{2}{|c|}{$921 \mathrm{~B}-3 \mathrm{R}-1,134-137 \mathrm{~cm}$} & \multicolumn{5}{|c|}{$921 \mathrm{~B}-3 \mathrm{R}-1,71-79 \mathrm{~cm}$} & \multicolumn{3}{|c|}{$921 \mathrm{C}-2 \mathrm{R}-1,70-78 \mathrm{~cm}$} \\
\hline & & 2 & 2 & 3 & 3 & 1 & 1 & 0 & 0 & 3 & 3 & 3 & 3 & 3 & 3 & 3 & 2 \\
\hline & $\mathrm{P}$ & $\mathrm{P}$ & $\mathrm{R}$ & $P$ & $\mathrm{P}$ & $\mathrm{P}$ & $\mathrm{P}$ & $\mathrm{P}$ & $R$ vein & $\mathrm{P}$ & $\mathrm{P}$ & $\mathrm{R}$ & $P$ & $\mathrm{R}$ & $\mathrm{R}$ & $\mathrm{P}$ & $\mathrm{P}$ \\
\hline $\mathrm{Na}_{2} \mathrm{O}$ & 0.45 & 0.42 & 0.33 & 0.37 & 0.36 & 0.47 & 0.36 & 0.46 & 0.45 & 0.36 & 0.4 & 0.36 & 0.44 & 0.36 & 0.34 & 0.46 & 0.38 \\
\hline $\mathrm{Cr}_{2} \mathrm{O}_{3}$ & 0 & 0.07 & 0.02 & 0.02 & 0.000 & 1.05 & 0.43 & 0.05 & 0.03 & 0.13 & 0.21 & 0.09 & 0 & 0.03 & 0.35 & 0.59 & 0.28 \\
\hline $\mathrm{MgO}$ & 13.34 & 14.58 & 14.12 & 13.19 & 15.4 & 15.32 & 15.87 & 14.95 & 14.85 & 14.45 & 15.23 & 14.18 & 12.85 & 12.94 & 15.66 & 15.42 & 15.4 \\
\hline $\mathrm{Al}_{2} \mathrm{O}_{3}$ & 1.96 & 2.48 & 1.36 & 1.04 & 1.87 & 3.54 & 2.82 & 2.57 & 2.25 & 2.55 & 3 & 2.44 & 2.09 & 1.78 & 1.96 & 3.28 & 2.26 \\
\hline $\mathrm{SiO}_{2}$ & 51.83 & 51.93 & 52.22 & 52.28 & 51.68 & 50.93 & 51.92 & 52.36 & 52.55 & 51.29 & 51.98 & 51.53 & 51.22 & 51.4 & 52.67 & 52.23 & 52.51 \\
\hline $\mathrm{CaO}$ & 19.92 & 20.82 & 21.15 & 20.48 & 19.85 & 21.72 & 22.85 & 21.03 & 21.38 & 20.47 & 21.6 & 20.53 & 20.2 & 20.07 & 22.22 & 21.25 & 21.73 \\
\hline $\mathrm{TiO}_{2}$ & 0.61 & 0.82 & 0.49 & 0.37 & 0.62 & 0.88 & 1.04 & 0.75 & 0.72 & 0.8 & 0.6 & 0.82 & 0.75 & 0.5 & 0.55 & 0.47 & 0.44 \\
\hline $\mathrm{MnO}$ & 0.32 & 0.23 & 0.3 & 0.38 & $\begin{array}{l}0.02 \\
0.31\end{array}$ & $\begin{array}{l}0.08 \\
0.13\end{array}$ & 0.12 & 0.23 & 0.22 & $\begin{array}{l}0.8 \\
0.24\end{array}$ & 0.2 & 0.22 & 0.4 & 0.39 & 0.17 & $\begin{array}{l}0.41 \\
0.21\end{array}$ & 0.17 \\
\hline $\mathrm{FeO}$ & 11.78 & 8.2 & 9.34 & 11.67 & 8.36 & 4.54 & 4.13 & 7.81 & 7.65 & 9.14 & 6.34 & 8.61 & 11.34 & 11.69 & 4.76 & 5.57 & 5.88 \\
\hline $\mathrm{NiO}$ & 0 & 0.01 & 0.03 & 0.08 & 0.000 & 0.05 & 0.01 & 0.02 & 0.02 & 0 & 0.04 & 0 & 0.04 & 0.01 & 0.01 & 0 & 0.03 \\
\hline CalcTotal & 100.21 & 99.55 & 99.37 & 99.88 & 98.47 & 98.64 & 99.56 & 100.26 & 100.15 & 99.43 & 99. & 98.78 & 99.32 & 99. & 98.71 & 99.48 & 99.09 \\
\hline $\mathrm{Mg \#}$ & 66.867 & 76.027 & 72.933 & 66.83 & 76.652 & 85.742 & 87.271 & 77.346 & 77.579 & 73.81 & 81.067 & 74.597 & 66.891 & 66.355 & 85.415 & 83.156 & 82.356 \\
\hline
\end{tabular}


Table 5. Selected microprobe analyses of plagioclase in gabbroic rocks listed in Table 3.

\begin{tabular}{|c|c|c|c|c|c|c|c|c|c|c|c|c|c|c|c|c|}
\hline \multirow{3}{*}{$\begin{array}{l}\text { Sample no: } \\
\text { Text. type: }\end{array}$} & \multirow{3}{*}{$\begin{array}{c}\begin{array}{c}921 \mathrm{E}-7 \mathrm{R}-1, \\
25-29 \mathrm{~cm}\end{array} \\
0 \\
\mathrm{P}\end{array}$} & \multicolumn{4}{|c|}{$921 \mathrm{E}-2 \mathrm{R}-2,56-60 \mathrm{~cm}$} & \multicolumn{6}{|c|}{$921 \mathrm{E}-7 \mathrm{R}-2,70-75 \mathrm{~cm}$} & \multicolumn{3}{|c|}{$923 \mathrm{~A}-2 \mathrm{R}-1,13-16 \mathrm{~cm}$} & \multicolumn{2}{|c|}{$923 \mathrm{~A}-12 \mathrm{R}-2,26-31 \mathrm{~cm}$} \\
\hline & & 1 & 1 & 4 & 4 & 0 & 0 & 4 & 4 & 4 & 0 & 3 & 3 & 3 & 0 & 0 \\
\hline & & $P$ & $P$ & $P$ & $R$ & $P$ & $P$ & $P$ & $R$ & $R$ & $P$ & $P$ & $R$ & $P$ & $P$ & $P$ \\
\hline $\mathrm{Na}_{2} \mathrm{O}$ & 8.26 & 5.86 & 4.51 & 7.11 & 7.68 & 3.57 & 2.68 & 3.44 & 5.31 & 8.53 & 8.65 & 6.08 & 6.08 & 5.58 & 4.64 & 5.04 \\
\hline $\mathrm{MgO}$ & 0 & 0.03 & 0.01 & 0.03 & 0.01 & 0.02 & 0.01 & 0.01 & 0 & 0 & 0.01 & 0.04 & 0.04 & 0.02 & 0.04 & 0.03 \\
\hline $\mathrm{Al}_{2} \mathrm{O}_{3}$ & 24.03 & 27.88 & 30.19 & 26.21 & 25.35 & 30.71 & 32.13 & 30.71 & 28.33 & 23.92 & 23.04 & 27.35 & 27.46 & 28.36 & 29.74 & 29.01 \\
\hline $\mathrm{SiO}_{2}{ }^{3}$ & 62.07 & 56.1 & 53.02 & 58.74 & 60.45 & 50.91 & 49.02 & 50.9 & 54.92 & 61.46 & 62.74 & 56.59 & 56.55 & 55.35 & 52.98 & 53.86 \\
\hline $\begin{array}{l}\mathrm{SaO}_{2} \\
\mathrm{CaO}\end{array}$ & 5.72 & 10.49 & 12.75 & 8.17 & $\begin{array}{r}0.43 \\
7.18\end{array}$ & 14.16 & 15.58 & 14.24 & 11.01 & 5.7 & $\begin{array}{r}0.74 \\
4.88\end{array}$ & 9.83 & 10.14 & 10.84 & 12.35 & 11.73 \\
\hline $\mathrm{TiO}_{2}$ & 0.02 & 0.1 & 0.08 & 0.04 & 0.03 & $\begin{array}{r}1.10 \\
0.06\end{array}$ & 0.01 & $\begin{array}{r}14.24 \\
0.04\end{array}$ & 0.01 & 0.12 & $\begin{array}{l}4.88 \\
0.02\end{array}$ & 0.05 & $\begin{array}{r}10.14 \\
0.04\end{array}$ & $\begin{array}{r}10.84 \\
0.04\end{array}$ & 0.06 & 0.11 \\
\hline $\mathrm{FeO}^{2}$ & 0.22 & 0.22 & 0.22 & 0.16 & 0.16 & 0.19 & 0.29 & 0.16 & 0.15 & 0.19 & 0.17 & 0.32 & 0.3 & 0.27 & 0.31 & 0.28 \\
\hline $\mathrm{K}_{2} \mathrm{O}$ & 0.29 & 0.08 & 0.04 & 0.12 & 0.11 & 0.02 & 0.02 & 0.04 & 0.05 & 0.13 & 0.25 & 0.08 & 0.1 & 0.05 & 0.02 & 0.05 \\
\hline CalcTotal & 100.65 & 100.77 & 100.84 & 100.57 & 100.98 & 99.75 & 99.82 & 99.55 & 99.8 & 99.94 & 99.77 & 100.34 & 100.72 & 100.53 & 100.12 & 100.12 \\
\hline Mg\# & 2.384 & 18.018 & 9.73 & 24.818 & 10.138 & 17.491 & 6.804 & 11.728 & 0 & 4.436 & 7.868 & 16.575 & 20.459 & 10.622 & 17.383 & 17.622 \\
\hline Albite & 71.139 & 50.03 & 38.946 & 60.751 & 65.555 & 31.28 & 23.73 & 30.351 & 46.497 & 72.506 & 75.139 & 52.55 & 51.748 & 48.11 & 40.424 & 43.614 \\
\hline Anorthite & 27.222 & 49.515 & 60.798 & 38.591 & 33.849 & 68.576 & 76.177 & 69.434 & 53.232 & 26.751 & 23.443 & 46.983 & 47.698 & 51.595 & 59.473 & 56.073 \\
\hline Orthoclase & 1.639 & 0.455 & 0.256 & 0.658 & 0.595 & 0.144 & 0.093 & 0.215 & 0.271 & 0.744 & 1.418 & 0.467 & 0.554 & 0.295 & 0.103 & 0.313 \\
\hline
\end{tabular}

Notes: Text. type $=$ textural type; $P=$ porphyroclast core; Prim $=$ porphyroclast $\operatorname{rim} ; \mathrm{R}=$ recrystallized.

Table 5 (continued).

\begin{tabular}{|c|c|c|c|c|c|c|c|c|c|c|c|c|c|c|c|c|c|c|c|c|}
\hline \multirow{3}{*}{$\begin{array}{l}\text { Sample no: } \\
\text { Text. type: }\end{array}$} & \multicolumn{7}{|c|}{$921 \mathrm{E}-3 \mathrm{R}-1,37-41 \mathrm{~cm}$} & \multicolumn{3}{|c|}{$921 \mathrm{E}-2 \mathrm{R}-2,78-81 \mathrm{~cm}$} & \multicolumn{4}{|c|}{$921 \mathrm{E}-3 \mathrm{R}-1,25-30 \mathrm{~cm}$} & \multicolumn{2}{|c|}{$921 \mathrm{E}-1 \mathrm{R}-1,16-23 \mathrm{~cm}$} & \multicolumn{4}{|c|}{$923 \mathrm{~A}-13 \mathrm{R}-1,124-128 \mathrm{~cm}$} \\
\hline & 2 & 2 & 2 & 2 & 0 & 1 & 1 & 1 & 1 & 1 & 1 & 1 & 0 & 0 & 1 & 1 & 2 & 2 & 4 & 4 \\
\hline & $P$ & $\mathrm{P}$ & $\mathrm{R}$ & $P$ & $P$ & $\mathrm{P}$ & $\mathrm{R}$ & $P$ & $P$ & $\mathrm{R}$ & $P$ & $P$ & $\mathrm{P}$ & $P$ & $\mathrm{P}$ & $P$ & $P$ & $\mathrm{R}$ & R & $\mathrm{R}$ \\
\hline $\mathrm{Na}_{2} \mathrm{O}$ & 4.31 & 6.92 & 6.84 & 6.83 & 8.27 & 6.91 & 6.85 & 4.7 & 5.36 & 4.67 & 5.32 & 6.43 & 7.78 & 9.7 & 4.81 & 5.5 & 3.98 & 4.63 & 3.75 & 5.39 \\
\hline $\mathrm{MgO}$ & & & & & 0 & & & & & & & & & 0 & & 0 & 0.02 & & 0 & 0.02 \\
\hline $\mathrm{Al}_{2} \mathrm{O}_{3}$ & 30.12 & 26.11 & 26.17 & 26.24 & 24.14 & 25.88 & 26.47 & 29.53 & 28.64 & 29.3 & 28.89 & 27.09 & 24.63 & 21.91 & 29.47 & 28.52 & 30.63 & 29.65 & 30.99 & 28.94 \\
\hline $\mathrm{SiO}_{2}$ & 53.54 & 58.86 & 58.95 & 58.98 & 62.62 & 58.69 & 58.91 & 53.94 & 55.31 & 54.33 & 55.5 & 58.14 & 61.18 & 66.02 & 54.35 & 55.57 & 52.18 & 53.98 & 51.96 & 55.52 \\
\hline $\mathrm{CaO}$ & 12.14 & 7.7 & 7.89 & 7.88 & 5.4 & 7.7 & 7.98 & 11.81 & 10.62 & 11.8 & 10.76 & 8.74 & 6.06 & 2.73 & 11.34 & 10.26 & 13.47 & 12.16 & 13.59 & 11.06 \\
\hline $\mathrm{TiO}_{2}$ & 0.06 & 0.05 & 0.02 & 0.02 & 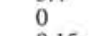 & 0.04 & 0.02 & 0.08 & 0.0 & 0.06 & 0.07 & 0.08 & 0.01 & 0.0 & 0.06 & 0.0 & 0.05 & 0.04 & 0.04 & 0.04 \\
\hline $\mathrm{FeO}^{2}$ & 0.23 & & & 0.23 & 0.15 & & & 0.25 & 0.1 & 0.2 & 0.2 & 0.29 & 0.14 & 0.14 & 0.17 & 0.14 & 0.18 & 0.28 & 0.23 & 0.16 \\
\hline $\mathrm{K}_{2} \mathrm{O}$ & 0.08 & 0.16 & 0.17 & 0.17 & 0.28 & 0.09 & 0.08 & 0.09 & 0.06 & 0.05 & 0.07 & 0.13 & 0.16 & 0.31 & 0.07 & 0.08 & 0.02 & 0.05 & 0.03 & 0.05 \\
\hline CalcTotal & 100.5 & 100.04 & 100.34 & 100.37 & 100.87 & 99.62 & 100.5 & 100.41 & 100.32 & 100.54 & 100.86 & 100.99 & 100 & 100.87 & 100.33 & 100.14 & 100.56 & 100.82 & 100.66 & 101.22 \\
\hline Mg\# & 9.3 & 13.818 & 9.153 & 7.193 & 3.465 & 14.537 & 13.649 & 17.564 & 15.661 & 14.354 & 15.259 & 12.462 & 8.292 & 5.829 & 26.618 & 6.026 & 18.054 & 12.285 & 3.7 & 22.22 \\
\hline Albite & 38.914 & 61.313 & 60.455 & 60.488 & 72.296 & 61.59 & 60.561 & 41.636 & 47.554 & 41.601 & 47.037 & 56.708 & 69.26 & 85.02 & 43.234 & 49.053 & 34.815 & 40.676 & 33.225 & 46.73 \\
\hline Anorthite & 60.622 & 37.725 & 38.538 & 38.544 & 26.104 & 37.906 & 38.997 & 57.839 & 52.096 & 58. & 52.573 & 42.549 & 29.786 & 13.214 & 56.34 & 50.508 & 65.087 & 59.041 & 66.611 & 53.007 \\
\hline Orthoclase & 0.464 & 0.962 & 1.007 & 0.967 & 1.6 & 0.504 & 0.442 & 0.525 & 0.351 & 0.305 & 0.39 & 0.742 & 0.954 & 1.767 & 0.426 & 0.439 & 0.098 & 0.283 & 0.163 & 0.262 \\
\hline
\end{tabular}

Table 5 (continued).

\begin{tabular}{|c|c|c|c|c|c|c|c|c|c|c|c|c|c|c|c|c|c|c|}
\hline \multirow{3}{*}{$\begin{array}{l}\text { Sample no: } \\
\text { Text. type: }\end{array}$} & \multicolumn{3}{|c|}{$923 \mathrm{~A}-13 \mathrm{R}-1,136-142 \mathrm{~cm}$} & \multicolumn{7}{|c|}{$923 \mathrm{~A}-2 \mathrm{R}-2,30-33 \mathrm{~cm}$} & \multicolumn{5}{|c|}{$921 \mathrm{E}-7 \mathrm{R}-2,94-100 \mathrm{~cm}$} & \multicolumn{3}{|c|}{ 921E-3R-1, 3-9 cm } \\
\hline & 3 & 3 & 4 & 1 & 3 & 3 & 4 & 4 & 2 & 2 & 0 & 0 & 0 & 0 & 0 & 3 & 3 & 3 \\
\hline & P & $\mathrm{R}$ & $\mathbf{R}$ & $\mathbf{P}$ & $\mathbf{P}$ & $\mathbf{R}$ & $\mathrm{R}$ & $\mathrm{R}$ & P & $\mathbf{R}$ & $\mathrm{P}$ & $\mathrm{P}$ & $\mathbf{P}$ & $\mathrm{P}$ & P rim & $\mathrm{P}$ & $\mathrm{R}$ & $\mathrm{R}$ \\
\hline $\mathrm{Na}_{2} \mathrm{O}$ & 4.24 & 5.23 & 4.9 & 5.92 & 6.03 & 6.14 & 3.67 & 5.53 & 5.68 & 5.78 & 3.88 & 7.11 & 7.59 & 8.39 & 10.03 & 4.23 & 7.06 & 6.79 \\
\hline $\mathrm{MgO}$ & 0.03 & 0.01 & 0.01 & 0.04 & 0.02 & 0.01 & 0.02 & 0.02 & 0.03 & 0.03 & 0 & 0 & 0.01 & 0 & 0 & 0.01 & 0.01 & 0 \\
\hline $\mathrm{Al}_{2} \mathrm{O}_{3}$ & 30.08 & 28.84 & 29.26 & 27.75 & 27.93 & 27.81 & 30.96 & 28.6 & 27.53 & 27.76 & 31.23 & 26.18 & 25.17 & 24.2 & 21.54 & 30.3 & 26.04 & 26.69 \\
\hline $\begin{array}{l}\mathrm{A}_{2} \mathrm{O}_{3} \\
\mathrm{SiO}\end{array}$ & 53.29 & 55.34 & 54.57 & 56.03 & 56.66 & 56.55 & 50.9 & 55.57 & 55.67 & 55.54 & 52.39 & 58.82 & 60.85 & 62.07 & 65.87 & 52.61 & 59.01 & 58.41 \\
\hline $\mathrm{CaO}$ & 12.77 & 10.92 & 11.63 & 10.18 & 9.95 & 9.79 & 13.77 & 10.77 & 10.06 & 10.11 & 13.33 & 7.55 & $\begin{array}{l}0.5 \\
6.5\end{array}$ & 5.29 & $\begin{array}{l}0.37 \\
2.37\end{array}$ & 12.35 & 7.44 & $\begin{array}{l}30.11 \\
8.11\end{array}$ \\
\hline $\mathrm{TiO}_{2}$ & 0.05 & 0.05 & 0.03 & $\begin{array}{r}10.18 \\
0.12\end{array}$ & 0.09 & 0.04 & 0.05 & 0 & 0.04 & 0.04 & 0.06 & 0.03 & 0.04 & 0.02 & 0.01 & 0.07 & 0.02 & $\begin{array}{l}0.11 \\
0.04\end{array}$ \\
\hline $\mathrm{FeO}^{2}$ & 0.25 & 0.25 & 0.18 & 0.37 & 0.25 & 0.3 & 0.29 & 0.18 & 0.24 & 0.25 & 0.2 & 0.19 & 0.27 & 0.29 & 0.17 & 0.26 & 0.23 & 0.52 \\
\hline $\mathrm{K}_{2} \mathrm{O}$ & 0.05 & 0.1 & 0.06 & 0.08 & 0.11 & 0.07 & 0.02 & 0.05 & 0.08 & 0.06 & 0.02 & 0.08 & 0.31 & 0.38 & 0.45 & 0.05 & 0.11 & 0.1 \\
\hline CalcTotal & 100.76 & 100.8 & 100.65 & 100.6 & 101.05 & 100.74 & 99.7 & 100.8 & 99.35 & 99.58 & 101.11 & 99.98 & 100.75 & 100.68 & 100.44 & 99.89 & 99.94 & 100.67 \\
\hline Albite & 37.418 & 46.177 & 43.111 & 51.044 & 51.988 & 52.92 & 32.511 & 48.021 & 50.306 & 50.707 & 34.473 & 62.698 & 66.694 & 72.551 & 86.23 & 38.165 & 62.793 & 59.89 \\
\hline Anorthite & 62.28 & 53.254 & 56.559 & 48.479 & 47.399 & 46.671 & 67.343 & 51.682 & 49.21 & 48.965 & 65.41 & 36.832 & 31.526 & 25.304 & 11.236 & 61.532 & 36.592 & 39.541 \\
\hline Orthoclase & 0.302 & 0.569 & 0.33 & 0.476 & 0.613 & 0.409 & 0.146 & 0.297 & 0.483 & 0.329 & 0.117 & 0.47 & 1.78 & 2.146 & 2.534 & 0.302 & 0.615 & 0.569 \\
\hline
\end{tabular}


Table 5 (continued).

\begin{tabular}{|c|c|c|c|c|c|c|c|c|c|c|c|c|c|c|c|c|c|}
\hline \multirow{3}{*}{$\begin{array}{l}\text { Sample no: } \\
\text { Text. type: }\end{array}$} & \multicolumn{4}{|c|}{$923 \mathrm{~A}-16 \mathrm{R}-4,85-89 \mathrm{~cm}$} & \multicolumn{3}{|c|}{$923 \mathrm{~A}-11 \mathrm{R}-1,95-101 \mathrm{~cm}$} & \multicolumn{4}{|c|}{$923 \mathrm{~A}-3 \mathrm{R}-2,51-57 \mathrm{~cm}$} & \multicolumn{6}{|c|}{$923 \mathrm{~A}-8 \mathrm{R}-1,31-46 \mathrm{~cm}$} \\
\hline & 2 & 2 & 0 & 0 & 2 & 2 & 4 & 2 & 2 & 4 & 0 & 0 & 0 & 0 & 0 & 0 & 0 \\
\hline & P & $\mathrm{R}$ & $P$ & $\mathrm{P}$ & $\mathrm{P}$ & $\mathrm{P}$ & $\mathbf{R}$ & $\mathrm{P}$ & $\mathrm{R}$ & $\mathrm{R}$ & $\mathrm{P}$ & $\mathrm{P}$ & $P$ & $\mathrm{P}$ & P & $\mathrm{P}$ & $\mathrm{P}$ \\
\hline $\mathrm{Na}_{2} \mathrm{O}$ & 4.71 & 5.11 & 10.47 & 7.34 & 4.55 & 4.83 & 4.79 & 4.81 & 5.12 & 5.89 & 6.14 & 2.6 & 3.76 & 3.11 & 4.01 & 3.46 & 5.1 \\
\hline $\mathrm{MgO}$ & 0.03 & 0.01 & 0.000 & 0.02 & 0.01 & 0.01 & 0 & 0.02 & 0.02 & 0.02 & 0.02 & 0.02 & 0.04 & 0.03 & 0.03 & 0.03 & 0.03 \\
\hline $\mathrm{Al}_{2} \mathrm{O}_{3}$ & 29.33 & 28.8 & 21.33 & 25.28 & 29.16 & 29.61 & 29.29 & 28.76 & 28.39 & 27.37 & 27.18 & 32.39 & 30.55 & 31.78 & 30.64 & 31.06 & 28.88 \\
\hline $\mathrm{SiO}_{2}$ & 53.74 & 54.7 & 66.07 & 59.03 & 53.14 & 53.93 & 53.65 & 53.38 & 54.39 & 56.15 & 56.27 & 48.89 & 51.42 & 49.62 & 51.77 & 51.19 & 55.03 \\
\hline $\mathrm{CaO}$ & 11.86 & 11.15 & 2.21 & 7.19 & 12.21 & 11.94 & 11.53 & 11.82 & 11.06 & 9.9 & 9.58 & $\begin{array}{l}+0.03 \\
15.67\end{array}$ & 13.71 & 15.21 & 13.57 & 14.11 & 11.41 \\
\hline $\mathrm{TiO}_{2}$ & 0.08 & 0.05 & 0.01 & 0.04 & 0.06 & 0.06 & 0.04 & 0.07 & 0.03 & 0.04 & 0.04 & 0.04 & 0.07 & 0.06 & 0.08 & 0.04 & 0.09 \\
\hline $\mathrm{FeO}$ & 0.27 & 0.21 & 0.01 & 0.27 & 0.3 & 0.24 & 0.21 & 0.31 & 0.21 & 0.31 & 0.31 & 0.28 & 0.25 & 0.3 & 0.29 & 0.35 & 0.29 \\
\hline $\mathrm{K}_{2} \mathrm{O}$ & 0.06 & 0.07 & 0.06 & 0.26 & 0.05 & 0.06 & 0.04 & 0.08 & 0.04 & 0.08 & 0.09 & 0.03 & 0.05 & 0.04 & 0.04 & 0.02 & 0.06 \\
\hline CalcTotal & 100.14 & 100.11 & 100.19 & 99.47 & 99.51 & 100.74 & 99.56 & 99.28 & 99.26 & 99.78 & 99.62 & 99.96 & 99.86 & 100.16 & 100.43 & 100.32 & 100.92 \\
\hline $\mathrm{Mg} \#$ & 15.225 & 11.295 & 0.000 & 13.183 & 7.238 & 8.907 & 2.472 & 9.352 & 12.507 & 11.198 & 9.463 & 12.975 & 24.515 & 13.786 & 16.629 & 14.118 & 16.961 \\
\hline Albite & 41.65 & 45.139 & 89.24 & 63.889 & 40.149 & 42.114 & 42.806 & 42.237 & 45.49 & 51.622 & 53.418 & 23.055 & 33.084 & 26.93 & 34.735 & 30.688 & 44.579 \\
\hline Anorthite & 57.977 & 54.454 & 10.418 & 34.598 & 59.566 & 57.559 & 56.958 & 57.284 & 54.282 & 47.94 & 46.09 & 76.746 & 66.615 & 72.865 & 65.019 & 69.207 & 55.082 \\
\hline Orthoclase & 0.373 & 0.407 & 0.342 & 1.513 & 0.285 & 0.327 & 0.235 & 0.479 & 0.228 & 0.438 & 0.493 & 0.198 & 0.301 & 0.205 & 0.245 & 0.105 & 0.339 \\
\hline
\end{tabular}

Table 5 (continued).

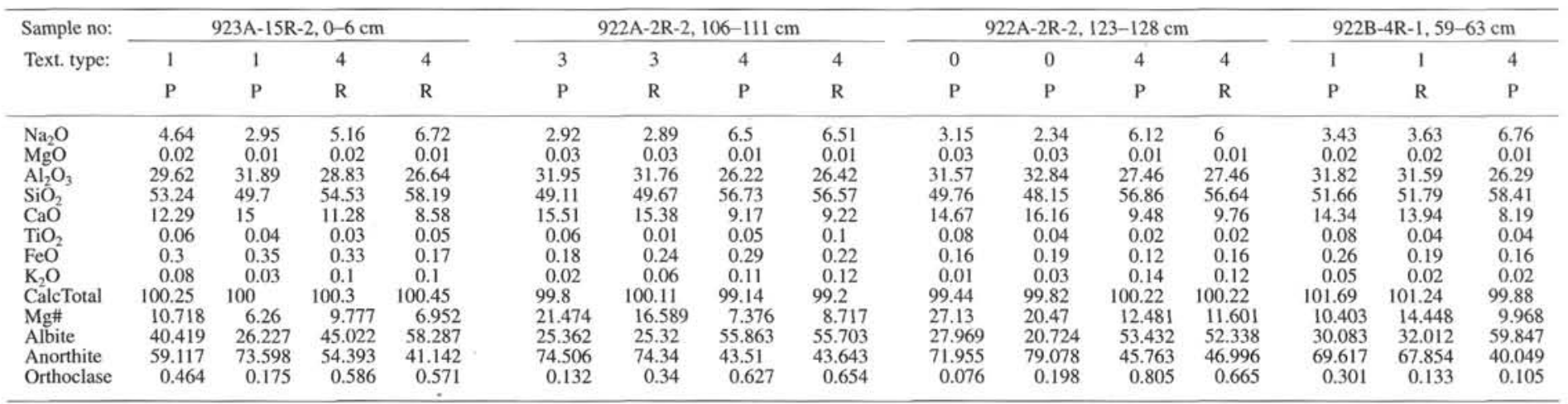

Table 5 (continued).

\begin{tabular}{|c|c|c|c|c|c|c|c|c|c|c|c|c|c|c|c|c|c|c|c|c|}
\hline \multirow{3}{*}{$\begin{array}{l}\text { Sample no: } \\
\text { Text. type: }\end{array}$} & \multicolumn{15}{|c|}{$922 \mathrm{~A}-2 \mathrm{R}-6,18-25 \mathrm{~cm}$} & \multicolumn{5}{|c|}{$922 \mathrm{~A}-3 \mathrm{R}-1,63-66 \mathrm{~cm}$} \\
\hline & 1 & 1 & 1 & 3 & 3 & 3 & 0 & 0 & 3 & 3 & 3 & 1 & 1 & 1 & 1 & 1 & 1 & 4 & 4 & 4 \\
\hline & P & P & $\mathrm{R}$ & P & $\mathrm{R}$ & $\mathrm{R}$ & P & P & P & $\mathrm{R}$ & $\mathrm{R}$ & $P$ & P & $\mathrm{R}$ & $\mathrm{R}$ & P & $\mathrm{R}$ & P & $\mathrm{R}$ & $\mathrm{R}$ \\
\hline $\mathrm{Na}_{2} \mathrm{O}$ & 5.87 & 3.17 & 5.66 & 2.64 & 2.58 & 4.82 & 8.18 & 7.39 & 3.16 & 3.34 & 6.09 & 4.94 & 2.5 & 4.83 & 2.82 & 2.15 & 2.24 & 2.76 & 2.64 & 6.68 \\
\hline $\mathrm{MgO}$ & 0.01 & 0.02 & 0.000 & 0.01 & 0.000 & 0.01 & $\begin{array}{l}.1 .18 \\
0.000\end{array}$ & 0.01 & 0.02 & 0.01 & 0.01 & 0.03 & 0.03 & 0.01 & 0.000 & 0.02 & 0.02 & 0.01 & 0.02 & $\begin{array}{l}0.001 \\
0.01\end{array}$ \\
\hline $\mathrm{Al}_{2} \mathrm{O}_{3}$ & 27.41 & 31.52 & 27.86 & 32.5 & 32.69 & 29.28 & 24.36 & 25.42 & 31.62 & 31.5 & 27.48 & 29.02 & 32.64 & 29.25 & 32.31 & 33.1 & 33.02 & 32.35 & 32.4 & 26.21 \\
\hline $\mathrm{SiO}_{2}$ & 56.69 & 50.73 & 56.29 & 49.27 & 49.03 & 54.6 & 62.19 & 60.46 & 50.37 & 50.39 & 57.39 & 54.28 & 48.08 & 53.67 & 49.35 & 48.11 & 48.04 & 48.78 & 48.48 & 58.09 \\
\hline $\mathrm{CaO}$ & 9.57 & 14.55 & 10.18 & 15.41 & 15.58 & 11.62 & 5.67 & 7.14 & 14.56 & 14.53 & 9.35 & 11.45 & 15.97 & 11.77 & $\begin{array}{l}15.38 \\
15.38\end{array}$ & $\begin{array}{l}40.11 \\
16.37\end{array}$ & 16.49 & 15.44 & $\begin{array}{l}40.40 \\
15.71\end{array}$ & 8.2 \\
\hline $\mathrm{TiO}_{2}$ & 0.05 & 0.08 & $\begin{array}{r}0.07 \\
0.07\end{array}$ & 0.04 & $\begin{array}{l}0.03 \\
0.03\end{array}$ & $\begin{array}{l}11.02 \\
0.03\end{array}$ & 0.03 & 0.02 & $\begin{array}{r}14.30 \\
0.06\end{array}$ & 0.05 & $\begin{array}{l}\text { P.J3 } \\
0.04\end{array}$ & 0.11 & 0.04 & 0.05 & 0.04 & 0.04 & $\begin{array}{r}0.49 \\
0.01\end{array}$ & 0.05 & 0.04 & 0.06 \\
\hline $\mathrm{FeO}^{2}$ & 0.19 & 0.35 & 0.19 & 0.18 & 0.23 & 0.2 & 0.08 & 0.22 & 0.3 & 0.19 & 0.15 & 0.23 & 0.17 & 0.18 & 0.2 & 0.17 & 0.23 & 0.16 & 0.16 & 0.15 \\
\hline $\mathrm{K}_{2} \mathrm{O}$ & 0.15 & 0.04 & 0.12 & 0.02 & 0.03 & 0.05 & 0.05 & 0.24 & 0.02 & 0.03 & 0.1 & 0.08 & 0.03 & 0.05 & 0.02 & 0.02 & 0.02 & 0.01 & 0.01 & 0.12 \\
\hline CalcTotal & 99.95 & 100.53 & 100.38 & 100.1 & 100.2 & 100.61 & 100.61 & 100.9 & 100.12 & 100.07 & 100.61 & 100.17 & 99.52 & 99.84 & 100.22 & 100.05 & 100.08 & 99.58 & 99.53 & 99.56 \\
\hline & 10.871 & 8.376 & 0.000 & 10.569 & 2.234 & 5.929 & 4.071 & 5.391 & 9.231 & 8.703 & 13.305 & 17.832 & 21.57 & 11.635 & 3.085 & 17.421 & 15.356 & 7.955 & 22.11 & 7.541 \\
\hline Albite & 52.148 & 28.208 & 49.813 & 23.621 & 23.041 & 42.778 & 72.098 & 64.293 & 28.19 & 29.294 & 53.77 & 43.655 & 22.057 & 42.489 & 24.858 & 19.183 & 19.695 & 24.425 & 23.314 & 59.126 \\
\hline Anorthite & 46.998 & 71.552 & 49.509 & 76.237 & 76.783 & 56.954 & 27.629 & 34.326 & 71.663 & 70.532 & 45.654 & 55.891 & 77.763 & $\begin{array}{l}42.409 \\
57.216\end{array}$ & $\begin{array}{l}2.0 .014 \\
75.014\end{array}$ & 80.688 & 80.189 & 75.529 & 76.604 & 40.157 \\
\hline Orthoclase & $\begin{array}{r}40.998 \\
0.854\end{array}$ & 0.24 & $\begin{array}{r}49.509 \\
0.678\end{array}$ & $\begin{array}{l}70.237 \\
0.141\end{array}$ & 0.176 & $\begin{array}{r}50.258 \\
0.268\end{array}$ & $\begin{array}{r}0.273 \\
0.273\end{array}$ & $\begin{array}{l}34.320 \\
1.38\end{array}$ & $\begin{array}{l}1.003 \\
0.147\end{array}$ & 0.173 & $\begin{array}{r}43.034 \\
0.576\end{array}$ & $\begin{array}{r}0.453 \\
0.453\end{array}$ & 0.18 & $\begin{array}{r}57.210 \\
0.295\end{array}$ & $\begin{array}{l}7.014 \\
0.128\end{array}$ & $\begin{array}{r}80.088 \\
0.129\end{array}$ & $\begin{array}{r}8.189 \\
0.116\end{array}$ & 0.047 & $\begin{array}{l}7.004 \\
0.081\end{array}$ & 0.717 \\
\hline
\end{tabular}


Table 5 (continued).

\begin{tabular}{|c|c|c|c|c|c|c|c|c|c|c|c|c|c|c|c|}
\hline \multirow{3}{*}{$\begin{array}{l}\text { Sample no: } \\
\text { Text. type: }\end{array}$} & \multicolumn{5}{|c|}{$922 \mathrm{~B}-4 \mathrm{R}-1,67-74 \mathrm{~cm}$} & \multicolumn{3}{|c|}{$922 \mathrm{~A}-2 \mathrm{R}-2,56-62 \mathrm{~cm}$} & \multicolumn{2}{|c|}{$921 \mathrm{~B}-3 \mathrm{R}-1,33-36 \mathrm{~cm}$} & \multicolumn{5}{|c|}{$921 \mathrm{~B}-3 \mathrm{R}-1,94-99 \mathrm{~cm}$} \\
\hline & 1 & 1 & 4 & 4 & 0 & 4 & 4 & 0 & 3 & 3 & 2 & 2 & 2 & 3 & 3 \\
\hline & $P$ & $P$ & $P$ & $\mathrm{R}$ & $P$ & $P$ & $\mathrm{R}$ & $P$ & $P$ & $\mathrm{R}$ & $P$ & $P$ & $\mathrm{R}$ & $P$ & R \\
\hline $\mathrm{Na}_{2} \mathrm{O}$ & 2.78 & 3.8 & 7.1 & 7.36 & 7.85 & 6.15 & 5.9 & 2.37 & 6.02 & 5.8 & 6.29 & 5.35 & 5.59 & 6.95 & 7.3 \\
\hline $\mathrm{MgO}$ & 0.02 & 0.02 & 0 & 0.01 & 0 & 0.01 & 0.01 & 0.03 & 0.02 & 0.02 & 0.03 & 0.02 & 0.01 & 0.01 & 0.01 \\
\hline $\mathrm{Al}_{2} \mathrm{O}_{3}$ & 32.49 & 30.61 & 25.97 & 25.89 & 25.3 & 27.01 & 27.15 & 32.58 & 27.64 & 28.05 & 26.77 & 28.32 & 28.1 & 25.9 & 25.31 \\
\hline $\mathrm{SiO}_{2}$ & 50 & 51.6 & 59.29 & 59.76 & 61.02 & 56.45 & 56.38 & 48.1 & 57.34 & 56.75 & 57.9 & 55.7 & 56.11 & 59.4 & 60.52 \\
\hline $\mathrm{CaO}^{2}$ & 15.4 & 13.5 & 7.94 & 7.51 & 6.68 & 9.42 & 9.46 & 15.94 & 9.46 & 9.96 & 8.98 & 10.78 & 10.32 & 7.71 & 7.06 \\
\hline $\mathrm{TiO}_{2}$ & 0.03 & 0.05 & 0.01 & 0.01 & 0 & 0.03 & 0.05 & 0.05 & 0.07 & 0.04 & 0.04 & 0.08 & 0.05 & 0.02 & 0.01 \\
\hline $\mathrm{FeO}_{2}$ & 0.21 & 0.19 & 0.21 & 0.12 & 0.19 & 0.12 & 0.11 & 0.17 & 0.22 & 0.19 & 0.27 & 0.19 & 0.11 & 0.16 & 0.15 \\
\hline $\mathrm{K}_{2} \mathrm{O}$ & 0.02 & 0.03 & 0.18 & 0 & 0.04 & 0.15 & 0.16 & 0.04 & 0.1 & 0.08 & 0.11 & 0.08 & 0.1 & 0.12 & 0.17 \\
\hline CalcTotal & 100.99 & 99.8 & 100.74 & 100.67 & $\begin{array}{l}101.09 \\
\end{array}$ & 99.33 & 99.24 & 99.29 & 100.92 & 100.89 & 100.39 & 100.52 & 100.39 & 100.28 & 100.56 \\
\hline Mg\# & 12.611 & 13.818 & 1.669 & 10.782 & 4.549 & 9.712 & 11.958 & 24.366 & $\begin{array}{l}15.92 \\
15.649\end{array}$ & $\begin{array}{l}15.87 \\
15.87\end{array}$ & 16.635 & 14.646 & 19.273 & $\begin{array}{l}100.28 \\
7.193\end{array}$ & $\begin{array}{l}100.618 \\
13.618\end{array}$ \\
\hline Albite & 24.602 & 33.666 & 61.187 & 63.957 & 67.902 & 53.694 & 52.529 & 21.138 & 53.217 & 51.05 & 55.544 & 47.064 & 49.204 & 61.579 & 64.559 \\
\hline Anorthite & 75.305 & 66.153 & 37.809 & 36.043 & 31.898 & 45.467 & 46.534 & 78.65 & 46.19 & 48.481 & 43.812 & 52.449 & 50.228 & 37.745 & 34.469 \\
\hline Orthoclase & 0.093 & 0.181 & 1.004 & 0 & 0.199 & 0.839 & 0.937 & 0.211 & 0.593 & $\begin{array}{r}\quad 0.469 \\
0.469\end{array}$ & 0.645 & 0.487 & 0.568 & 0.676 & 0.971 \\
\hline
\end{tabular}

Table 5 (continued).

\begin{tabular}{|c|c|c|c|c|c|c|c|c|c|c|c|c|c|}
\hline \multirow{3}{*}{$\begin{array}{l}\text { Sample no: } \\
\text { Text. type: }\end{array}$} & \multicolumn{11}{|c|}{$922 \mathrm{~B}-1 \mathrm{~W}-1,109-115 \mathrm{~cm}$} & \multicolumn{2}{|c|}{$921 \mathrm{~B}-3 \mathrm{R}-1,134-137 \mathrm{~cm}$} \\
\hline & 1 & 1 & 1 & 3 & 3 & 3 & 3 & 4 & 4 & 4 & 4 & 0 & 0 \\
\hline & $P$ & $P$ & R & P & $\mathrm{P}$ & R & $\mathrm{R}$ & $\mathrm{P}$ & $P$ & R & R & P & $\mathrm{R}$ vein \\
\hline $\mathrm{Na}_{2} \mathrm{O}$ & 3.19 & 2.27 & 2.74 & 6.18 & 2.88 & 6.24 & 2.28 & 2.22 & 3.06 & 2.59 & 4.15 & 5.08 & 4.94 \\
\hline $\mathrm{MgO}$ & 0.02 & 0.02 & 0.01 & 0.03 & 0.000 & 0.02 & 0.02 & 0.01 & 0.05 & 0.02 & 0.14 & 0.04 & 0.02 \\
\hline $\mathrm{Al}_{2} \mathrm{O}_{3}$ & 31.32 & 32.95 & 32.31 & 26.8 & 31.55 & 26.73 & 32.3 & 32.89 & 31.93 & 32.37 & 29.68 & 28.84 & 29.05 \\
\hline $\mathrm{SiO}_{2}$ & 49.86 & 48 & 49.36 & 56.72 & 48.8 & 56.61 & 47.66 & 47.55 & 49.64 & 48.72 & 52.79 & 54.72 & 54.34 \\
\hline $\mathrm{CaO}$ & 14.36 & 16.16 & 15.19 & 9.31 & 15.16 & 9.21 & 16.04 & 16.32 & 14.92 & 15.69 & 12.16 & 11.27 & 11.46 \\
\hline $\mathrm{TiO}_{2}$ & 0.04 & 0.04 & 0.07 & 0.05 & 0.07 & 0.05 & 0.04 & 0.03 & 0.06 & 0.04 & 0.03 & 0.06 & 0.05 \\
\hline $\mathrm{FeO}$ & 0.15 & 0.11 & 0.12 & 0.29 & 0.23 & 0.21 & 0.24 & 0.16 & 0.12 & 0.13 & 0.39 & 0.38 & 0.27 \\
\hline $\mathrm{K}_{2} \mathrm{O}$ & 0.04 & 0.02 & 0.03 & 0.11 & 0.02 & 0.12 & 0.03 & 0.03 & 0.05 & 0.04 & 0.05 & 0.05 & 0.05 \\
\hline CalcTotal & 99.02 & 99.58 & 99.85 & 99.52 & 98.71 & 99.2 & 98.62 & 99.22 & 99.86 & 99.62 & 99.4 & 100.49 & 100.22 \\
\hline Mg\# & 20.947 & 23.984 & 15.963 & 16.72 & 0.000 & 13.421 & 11.924 & 14.167 & 39.806 & 18.332 & 39.034 & 16.859 & 10.622 \\
\hline Albite & 28.616 & 20.211 & 24.533 & 54.223 & 25.528 & 54.69 & 20.423 & 19.718 & 26.961 & 22.93 & 38.072 & 44.765 & 43.675 \\
\hline Anorthite & 71.142 & 79.678 & 75.272 & 45.125 & 74.367 & 44.601 & 79.382 & 80.083 & 72.725 & 76.831 & 61.602 & 54.916 & 56.005 \\
\hline Orthoclase & 0.242 & 0.112 & 0.195 & 0.652 & 0.105 & 0.709 & 0.194 & 0.199 & 0.313 & 0.239 & 0.326 & 0.319 & 0.32 \\
\hline
\end{tabular}

Table 5 (continued).

\begin{tabular}{|c|c|c|c|c|c|c|c|c|c|c|c|c|}
\hline \multirow{3}{*}{$\begin{array}{l}\text { Sample no: } \\
\text { Text. type: }\end{array}$} & \multicolumn{6}{|c|}{$921 \mathrm{~B}-3 \mathrm{R}-1,71-79 \mathrm{~cm}$} & \multicolumn{6}{|c|}{$921 \mathrm{C}-2 \mathrm{R}-1,70-78 \mathrm{~cm}$} \\
\hline & 3 & 3 & 3 & 3 & 3 & 3 & 2 & 2 & 2 & 3 & 3 & 3 \\
\hline & $\mathrm{P}$ & P & $\mathbf{R}$ & P & $\mathrm{R}$ & $\mathrm{R}$ & $\mathrm{P}$ & $\mathrm{P}$ & $\mathrm{R}$ & P & $\mathrm{R}$ & $\mathrm{R}$ \\
\hline $\mathrm{Na}_{2} \mathrm{O}$ & 4.18 & 5.58 & 5.48 & 6.11 & 6.07 & 5.13 & 4 & 3.27 & 3.88 & 3.89 & 3.16 & 4.68 \\
\hline $\mathrm{MgO}$ & 0.01 & 0.03 & 0.01 & 0.02 & 0.01 & 0.03 & 0.02 & 0.02 & 0.01 & 0.01 & 0.01 & 0 \\
\hline $\mathrm{Al}_{2} \mathrm{O}_{3}$ & 30.17 & 28.31 & 28.37 & 27.02 & 27.4 & 28.85 & 30.48 & 31.5 & 30.75 & 30.61 & 31.8 & 29.43 \\
\hline $\mathrm{SiO}_{2}$ & 51.97 & 54.69 & 55.12 & 56.71 & 56.7 & 54.4 & 51.61 & 50.02 & 51.01 & 51.59 & 49.88 & 53.2 \\
\hline $\mathrm{CaO}$ & 12.94 & 10.74 & 10.77 & 9.34 & 9.58 & 11.25 & 13.06 & 14.44 & 13.52 & 13.28 & 14.54 & 11.81 \\
\hline $\mathrm{TiO}_{2}$ & 0.04 & 0.06 & 0.04 & 0.08 & 0.01 & 0.03 & 0.04 & 0.07 & 0.04 & 0.05 & 0.01 & 0.04 \\
\hline $\mathrm{FeO}_{2}$ & 0.27 & 0.22 & 0.11 & 0.27 & 0.22 & 0.53 & 0.18 & 0.14 & 0.1 & 0.09 & 0.17 & 0.14 \\
\hline $\mathrm{K}_{2} \mathrm{O}$ & 0.04 & 0.07 & 0.09 & 0.11 & 0.06 & 0.1 & 0.06 & 0.05 & 0.04 & 0.01 & 0.01 & 0.01 \\
\hline CalcTotal & 99.66 & 99.71 & 99.99 & 99.67 & 100.07 & 100.34 & 99.46 & 99.5 & 99.38 & 99.55 & 99.59 & 99.32 \\
\hline Mg\# & 7.392 & 18.841 & 11.295 & 10.159 & 9.011 & 8.667 & 16.532 & 18.755 & 11.295 & 12.671 & 13.32 & 0 \\
\hline Albite & 36.814 & 48.261 & 47.677 & 53.897 & 53.215 & 44.937 & 35.527 & 29 & 34.089 & 34.605 & 28.201 & 41.734 \\
\hline Anorthite & 62.972 & 51.34 & 51.779 & 45.482 & 46.444 & 54,498 & 64.117 & 70.731 & 65.674 & 65.336 & 71.758 & 58.225 \\
\hline Orthoclase & 0.214 & 0.398 & 0.544 & 0.621 & 0.341 & 0.565 & 0.357 & 0.268 & 0.237 & 0.059 & 0.041 & 0.041 \\
\hline
\end{tabular}




\begin{tabular}{|c|c|c|c|c|c|c|c|c|c|c|c|c|c|c|c|c|c|c|c|}
\hline \multirow{4}{*}{$\begin{array}{c}\text { Text. type: } \\
\text { Mineral }\end{array}$} & \multicolumn{5}{|c|}{$921 \mathrm{E}-2 \mathrm{R}-2,54-60 \mathrm{~cm}$} & \multicolumn{8}{|c|}{$921 \mathrm{E}-7 \mathrm{R}-2,70-75 \mathrm{~cm}$} & \multicolumn{6}{|c|}{ 923A-2R-1, 13-16 cm } \\
\hline & 1 & 4 & 4 & 1 & 4 & 0 & 0 & 4 & 4 & 4 & 4 & 0 & 4 & 3 & 3 & 3 & 3 & 3 & 3 \\
\hline & $\mathrm{OL}$ & OPX & OPX & $\mathrm{AM}$ & AM & OL & $\mathrm{OL}$ & OPX & OPX & OPX & OPX & $\mathrm{AM}$ & $\mathrm{AM}$ & $\mathrm{OL}$ & $\mathrm{OL}$ & OPX & OPX & AM & $\mathrm{AM}$ \\
\hline & $\mathrm{P}$ & $\mathbf{R}$ & P & Int & $\mathbf{R}$ & $\mathrm{P}$ & $\mathrm{P}$ & $\mathrm{R}$ & $\mathrm{P}$ & $\mathrm{P}$ & Prim & Int & & $\mathbf{P}$ & $\mathrm{P}$ & $\mathbf{R}$ & $\mathrm{P}$ & Incl & Int \\
\hline $\mathrm{Na}_{2} \mathrm{O}$ & 0 & 0.02 & 0.02 & 2.85 & 2.93 & 0.03 & 0.01 & 0.02 & 0.04 & 0.03 & 0.02 & 2.53 & 2 & 0.01 & 0 & 0.03 & 0.04 & 3.02 & 2.9 \\
\hline $\mathrm{Cr}_{2}$ & 0 & 0 & 18 & & 0 & 0 & 0.01 & & 0 & 0 & & 0.55 & 0.1 & 0 & 0 & & 0.01 & & 0.04 \\
\hline $\mathrm{MgO}$ & 33.24 & 20.46 & 18.29 & & 11.64 & 41 & 39.67 & 21.12 & 18.1 & 28.16 & 18.28 & 16.62 & 15.9 & 31.65 & 33.43 & 23.69 & 24.51 & 12.59 & 13.01 \\
\hline $\mathrm{Al}_{2} \mathrm{O}_{3}$ & 0 & 0.71 & 0 & 13.35 & 11.19 & 0 & 0 & 0.43 & 0.3 & 1.4 & 0.36 & 11.4 & 9.7 & 0 & 0 & 1.17 & 1.11 & 10.68 & 11 \\
\hline $\mathrm{SiO}_{2}$ & 36.71 & 52.44 & 51.3 & 41.83 & 42.14 & 38.5 & 38.63 & 52.99 & 51.58 & 54,17 & 52 & 44.01 & 46.35 & 36.73 & 36.95 & 52.78 & 53.31 & 42.51 & 42.34 \\
\hline $\mathrm{CaO}$ & 0.06 & 1.05 & 1.28 & 10.73 & 10.8 & 0.04 & 0.05 & 0.8 & 1.2 & 0. & 1.25 & 11. & 11. & 0. & 0.05 & 1.25 & 1.93 & 11.08 & 11.24 \\
\hline & & 0.22 & 0.24 & 2.68 & 3.12 & 0.01 & 0.01 & 0. & 0. & 0. & 0. & 2. & 1. & 0. & 0. & 0. & 0.54 & 4.33 & 4.14 \\
\hline $\mathrm{MnO}$ & 0.47 & 0.73 & 0.82 & 0.15 & 0.18 & 0.25 & 0.32 & 0.6 & 0.9 & 0. & 0. & 0.09 & 0.18 & 0. & 0.44 & 0. & 0.43 & 0.16 & 0.13 \\
\hline & 29.9 & 25.15 & 27.9 & 11.11 & 15.8 & 19.49 & 21.54 & 23.42 & 27.03 & 14.63 & 27.15 & 7.93 & 10.22 & 31. & 29.23 & 19. & 18. & 12.81 & 12.53 \\
\hline & 0.08 & 0 & 0. & 0.05 & 0. & 0.09 & 0.09 & 0.06 & 0 & 0.04 & 0.03 & & & 0.04 & 0.04 & 0.02 & 0 & 0 & 0.04 \\
\hline $\mathrm{K}_{2} \mathrm{O}$ & 0 & 0 & & 0.28 & 0. & & & & & & & & & 0 & 0 & & 0.01 & 0.18 & 0.18 \\
\hline CalcTotal & 100.48 & 100.8 & 100.39 & 96.9 & & 9.4 & 10 & 99.83 & & 9.2 & 80 . & & & & 100 & & & & 97.53 \\
\hline Mg\# & 66.465 & 59.186 & 53.881 & 69.034 & 56.779 & 78.951 & 76.653 & 61.65 & 54.509 & 77.436 & 54.555 & 78.899 & 73.498 & 64.216 & 67.094 & 68.327 & 70.737 & 63.668 & 64.923 \\
\hline
\end{tabular}

Notes: Text. type = textural type; $\mathrm{P}=$ porphyroclast core; Prim = porphyroclast rim; $\mathrm{R}=$ recrystallized, Int = interstitial; Incl = inclusion in igneous pyroxene; Incl $\mathrm{CPX}=$ inclusion in clinopyroxene; Exs CPX = exsolution in clinopyroxene.

Table 6 (continued).

\begin{tabular}{|c|c|c|c|c|c|c|c|c|c|c|c|c|c|c|c|c|c|}
\hline \multirow[b]{2}{*}{ Text. type: } & \multicolumn{5}{|c|}{$923 \mathrm{~A}-12 \mathrm{R}-2,26-31 \mathrm{~cm}$} & \multicolumn{6}{|c|}{$921 \mathrm{E}-3 \mathrm{R}-1,37-41 \mathrm{~cm}$} & \multicolumn{6}{|c|}{$921 \mathrm{E}-1 \mathrm{R}-1,16-23 \mathrm{~cm}$} \\
\hline & 0 & 0 & 0 & 0 & 0 & 2 & 2 & 1 & 2 & 2 & 1 & 1 & 1 & 1 & 1 & 1 & 1 \\
\hline \multirow[t]{2}{*}{ Mineral } & $\mathrm{OL}$ & $\mathrm{OL}$ & OPX & OPX & AM & OPX & OPX & OPX & AM & $\mathrm{AM}$ & $\mathrm{AM}$ & OL. & OPX & OPX & $\mathrm{AM}$ & AM & $\mathrm{AM}$ \\
\hline & P & P & P & Int & Int & P & Incl CPX & $P$ & Incl & & Int & $\mathbf{P}$ & $\mathbf{R}$ & P & Int & Incl & \\
\hline $\mathrm{Na}_{2} \mathrm{O}$ & 0.01 & 0.01 & 0 & 0.02 & 2.44 & 0.03 & 0.03 & 0.05 & 2.72 & 1.27 & 2.33 & 0 & 0.02 & 0.03 & 2.17 & 2.76 & 1.48 \\
\hline $\mathrm{Cr}_{2} \mathrm{O}_{3}$ & 0 & 0.01 & 0 & 0.03 & 0. & 0.02 & 0.04 & 0 & 0.03 & 0.01 & 0 & 0 & 003 & 0.03 & 0.05 & 0.11 & 0.01 \\
\hline $\mathrm{MgO}$ & 39.1 & 36.11 & 26.61 & 26.95 & 15.4 & 19.23 & 19 & 17.62 & 10.88 & 9.67 & 12.07 & 31.06 & 24.39 & 24.77 & 14.78 & 13.37 & 13.6 \\
\hline $\mathrm{Al}_{2} \mathrm{O}_{3}$ & 0 & 0 & 1.03 & 1.03 & 11.51 & 0.73 & 1.13 & 0.58 & 10.81 & 6.8 & 10.16 & 0 & 1.15 & 1.34 & 11.31 & 11.38 & 8.2 \\
\hline $\mathrm{SiO}_{2}{ }^{\prime}$ & 37.98 & 37.17 & 54.05 & 53.84 & 43.57 & 52.29 & 51.86 & 51.87 & 42.62 & 46.79 & 43.74 & 36.13 & 53.59 & 53.31 & 44.13 & 43.02 & 47.47 \\
\hline $\mathrm{CaO}$ & 0.04 & 0.05 & 0.96 & 1.14 & 11.82 & 1.4 & 1.15 & 2.18 & 10.51 & 10.89 & 10.39 & 0.01 & 1.25 & 1.94 & 11.06 & 10.85 & 11.34 \\
\hline $\mathrm{TiO}_{2}$ & 0 & 0.03 & & 0.43 & 2.8 & 0.26 & 0.23 & 0.28 & 3.65 & 1.03 & 2.86 & 0 & 0.37 & 0.5 & 2.43 & 4.1 & 0.76 \\
\hline $\mathrm{MnO}$ & 0.31 & 0.32 & 0.38 & 0.37 & 0.07 & 0.75 & 0.72 & 0.78 & 0.24 & 0.26 & 0.23 & 0.46 & 0.45 & 0.38 & 0.16 & 0.14 & 0.17 \\
\hline $\mathrm{FeO}$ & 22.61 & 25.92 & 16.82 & 15.79 & 8.55 & 26.12 & 26.51 & 26.68 & 15.96 & 20.63 & 15.23 & 31.82 & 18.78 & 16.82 & 10.06 & 11.06 & 13.15 \\
\hline $\mathrm{NiO}$ & 0.05 & & 0 & 0.02 & 0. & 0 & 0 & 0.02 & 0 & 0.02 & 0 & 0.06 & 0 & 0.02 & 0.05 & & \\
\hline $\mathrm{K}_{2} \mathrm{O}$ & 0 & 0.01 & 0 & 0.01 & 0.18 & 0 & 0 & 0.02 & 0.19 & 0.34 & 0.18 & 0 & 0 & & 0.28 & 0.12 & 0.13 \\
\hline CalcTotal & 100.11 & 99.73 & 100.21 & 99.65 & 96.47 & 100.84 & 100.67 & 100.1 & 97.6 & 97.72 & 97.18 & 99.55 & 100.02 & 99.16 & 96.5 & 96.91 & 96.3 \\
\hline Mg\# & 75.503 & 71.289 & 73.829 & 75.263 & 76.255 & 56.756 & 56.096 & 54.067 & 54.858 & 45.533 & 58.549 & 63.504 & 69.84 & 72.421 & 72.367 & 68.313 & 64.834 \\
\hline
\end{tabular}

Table 6 (continued).

\begin{tabular}{|c|c|c|c|c|c|c|c|c|c|c|c|c|c|c|c|c|}
\hline \multirow{4}{*}{$\begin{array}{c}\text { Text. type: } \\
\text { Mineral }\end{array}$} & \multicolumn{4}{|c|}{$921 \mathrm{E}-2 \mathrm{R}-2,78-81 \mathrm{~cm}$} & \multicolumn{4}{|c|}{$921 \mathrm{E}-3 \mathrm{R}-1,25-30 \mathrm{~cm}$} & \multicolumn{8}{|c|}{$923 \mathrm{~A}-13 \mathrm{R}-1,124-128 \mathrm{~cm}$} \\
\hline & 1 & 1 & 1 & 1 & 1 & 1 & 1 & 0 & 2 & 2 & 2 & 4 & 4 & 2 & 4 & 2 \\
\hline & $\mathrm{OL}$ & $\mathrm{AM}$ & $\mathrm{AM}$ & $\mathrm{AM}$ & $\mathrm{OL}$ & $\mathrm{AM}$ & $\mathrm{AM}$ & $\mathrm{AM}$ & $\mathrm{OL}$ & $\mathrm{OL}$ & OPX & OPX & OPX & $\mathrm{AM}$ & $\mathrm{AM}$ & $\mathrm{AM}$ \\
\hline & $\mathrm{P}$ & Int & $\mathrm{R}$ & & P & & Incl & Int & P & $\mathbf{R}$ & Int & P & R & & $\mathrm{R}$ & Int \\
\hline $\mathrm{Na}_{2} \mathrm{O}$ & 0.00 & 2.44 & 2.45 & 1.75 & 0.01 & 0.8 & 2.68 & 1 & 0 & 0.02 & 0.02 & 0.01 & 0.02 & 0.33 & 2.71 & 2.98 \\
\hline $\mathrm{Cr}_{2} \mathrm{O}_{3}$ & & & 0.05 & & & & & 0 & 0.02 & & & & & & & \\
\hline $\mathrm{MgO}$ & 32.52 & 12.06 & 15.15 & 15.38 & 27.21 & 12.29 & 13.09 & 12.54 & 34.33 & 34.55 & 27.18 & 23.88 & 23.99 & 13.67 & 13.73 & 15.09 \\
\hline $\mathrm{Al}_{2} \mathrm{O}_{3}$ & 0.00 & 11.78 & 11.88 & 10.13 & 0.00 & 4.35 & 11.35 & 4.23 & 0 & 0.01 & 0.97 & 1.05 & 0.96 & 2.96 & 11.36 & 11.86 \\
\hline $\mathrm{SiO}_{2}$ & 37.11 & 42.63 & 43.99 & 47.78 & 35.96 & 50.12 & 42.47 & 49.41 & 38.48 & 38.37 & 55.89 & 54.3 & 54.12 & 51.81 & 43.44 & 43.86 \\
\hline $\mathrm{CaO}$ & 0.03 & 11.28 & 11.45 & 11.96 & 0.04 & 11.22 & 11.23 & 10.01 & 0.06 & 0. & 1.01 & 1.17 & 1.11 & 14.89 & 11.34 & 11.55 \\
\hline & & 3.4 & 2.12 & 0. & & 0. & 4.62 & 0. & 0 & 0 & & 0. & 0.2 & 0.31 & 3.49 & \\
\hline $\mathrm{MnO}$ & 0.50 & 0.16 & 0.11 & 0.12 & 0.58 & 0.29 & $\begin{array}{l}4.02 \\
0.19\end{array}$ & 0.35 & 0.41 & 0.38 & 0.37 & 0.4 & 0.43 & 0.41 & 0.16 & 0.11 \\
\hline $\mathrm{FeO}$ & 30.63 & 14.1 & 10.48 & 10.39 & 37.65 & 18.31 & 12 & 18 & 26.87 & 27.05 & 15.2 & 19.04 & 19.7 & 12.33 & 10.74 & 8.24 \\
\hline $\mathrm{NiO}$ & & & & & 0 & 0. & 0 & & 0.08 & 0.06 & 0 & 0 & 0.0 & 0.01 & 0.03 & 0.02 \\
\hline $\mathrm{K}_{2} \mathrm{O}$ & 0.00 & 0.22 & 0.17 & 0. & 0. & 0.17 & 0.09 & 0.1 & 0 & 0 & 0 & 0 & 0 & 0.05 & 0.2 & 0.23 \\
\hline CalcTotal & 100.90 & 98.18 & 97.89 & 98.16 & 101.51 & 98.31 & 97.8 & 97.44 & 100.25 & 100.47 & 100.93 & 100.33 & 100.62 & 96.79 & 97.93 & 97.92 \\
\hline Mg\# & 65.430 & 60.353 & 72.035 & 72.512 & 56.296 & 54.469 & 66.041 & 54.385 & 69.49 & 69.48 & 76.119 & 69.094 & 68.462 & 66.402 & 69.514 & 76.548 \\
\hline
\end{tabular}


Table 6 (continued)

\begin{tabular}{|c|c|c|c|c|c|c|c|c|c|c|c|c|c|c|c|c|c|c|c|c|}
\hline \multirow{4}{*}{$\begin{array}{c}\text { Text. type: } \\
\text { Mineral }\end{array}$} & \multicolumn{8}{|c|}{$923 \mathrm{~A}-13 \mathrm{R}-1,136-142 \mathrm{~cm}$} & \multicolumn{12}{|c|}{$923 \mathrm{~A}-2 \mathrm{R}-2,30-33 \mathrm{~cm}$} \\
\hline & 4 & 3 & 3 & 3 & 4 & 3 & 3 & 4 & 4 & 1 & 2 & 4 & 4 & 3 & 1 & 4 & 4 & 1 & 4 & 4 \\
\hline & $\mathrm{OL}$ & OPX & OPX & OPX & OPX & $\mathrm{AM}$ & AM & $\mathrm{AM}$ & $\mathrm{OL}$ & $\mathrm{OL}$ & OPX & OPX & OPX & OPX & OPX & $\mathrm{AM}$ & $\mathrm{AM}$ & $\mathrm{AM}$ & BI & BI \\
\hline & $R$ & $P$ & $R$ & $R$ & $R$ & Incl & $R$ & $R$ & $R$ & $P$ & $R$ & P & $R$ & $P$ & $P$ & $R$ & & Int & $P$ & $\mathrm{P}$ \\
\hline $\mathrm{Na}_{2} \mathrm{O}$ & 0.000 & 0.04 & 0.02 & 0.02 & 0.02 & 2.91 & 2.97 & 2.88 & 0 & 0 & 0.04 & 0.02 & 0.02 & 0.01 & 0.03 & 2.65 & 1.95 & 2.64 & 0.26 & 0.59 \\
\hline $\mathrm{Cr}_{2} \mathrm{O}_{3}$ & 0.01 & 0.01 & 0.000 & 0.12 & 0.03 & 0.07 & 0.4 & 0.34 & 0 & 0 & 0 & 0.01 & 0 & 0.04 & 0 & 0.02 & 0 & 0.02 & 0.04 & 0.03 \\
\hline $\mathrm{MgO}$ & 33.67 & 24.54 & 23.6 & 25.66 & 26.27 & 12.91 & 13.91 & 14.25 & 30.66 & 30.3 & 23.33 & 24.11 & 23.83 & 22.85 & 23.2 & 13.58 & 12.69 & 13.09 & 16.43 & 16.5 \\
\hline $\mathrm{Al}_{2} \mathrm{O}_{3}$ & 0.000 & 1.31 & 0.95 & 1.43 & 1.13 & 11.26 & 11.2 & 11.82 & 0 & 0 & 0.91 & 1.1 & 0.79 & 1.01 & 1.22 & 11.57 & 9.05 & 11.53 & 13.15 & 13.53 \\
\hline $\mathrm{SiO}_{2}$ & 37.19 & 53.88 & 53.53 & 54.15 & 54.5 & 42.25 & 42.85 & 42.98 & 35.66 & 36.29 & 52.71 & 52.77 & 54.09 & 53.03 & 53.87 & 42.18 & 46.1 & 43.59 & 39.09 & 39.87 \\
\hline $\mathrm{CaO}$ & 0.07 & $\begin{array}{r}1.90 \\
1.94\end{array}$ & 1.23 & 1.11 & 1.08 & 11.32 & 11.34 & 11.33 & $\begin{array}{l}50.00 \\
0.01\end{array}$ & 0.06 & 1.63 & 1.28 & 0.84 & 1.62 & 1.8 & 11.12 & 11.84 & 11.62 & 0.03 & 0.07 \\
\hline $\mathrm{TiO}_{2}$ & 0.04 & $\begin{array}{l}0.41 \\
0.41\end{array}$ & 0.28 & 0.36 & 0.26 & 4.44 & $\begin{array}{r}1.34 \\
4.27\end{array}$ & 3.88 & 0.04 & $\begin{array}{l}0.00 \\
0.01\end{array}$ & $\begin{array}{l}1.03 \\
0.33\end{array}$ & $\begin{array}{l}1.28 \\
0.27\end{array}$ & 0.17 & $\begin{array}{l}1.02 \\
0.34\end{array}$ & 0.5 & 3.56 & $\begin{array}{r}11.84 \\
0.81\end{array}$ & 3.28 & 1.81 & 2.23 \\
\hline $\mathrm{MnO}_{2}$ & 0.44 & $\begin{array}{l}0.41 \\
0.41\end{array}$ & 0.48 & 0.41 & 0.45 & 0.18 & 0.16 & 0.15 & 0.52 & 0.46 & 0.52 & 0.52 & 0.57 & 0.55 & 0.53 & 0.14 & 0.22 & 0.21 & $\begin{array}{l}1.01 \\
0.09\end{array}$ & 0.1 \\
\hline $\mathrm{FeO}$ & 28.81 & 17.86 & 19.74 & 17.31 & 16.72 & 12.73 & 10.47 & 10.29 & 33.73 & 33.49 & 20.87 & 20.21 & 20.31 & 21.07 & 19.16 & 12.76 & 14.85 & 12.48 & 16.34 & 14.77 \\
\hline $\mathrm{NiO}$ & 0.04 & 0.01 & 0.02 & 0.02 & 0.04 & 0.03 & 0.05 & 0.05 & 0.08 & 0.1 & 0.04 & 0.05 & 0.06 & 0 & 0 & 0 & 0 & 0 & 0.01 & 0.05 \\
\hline $\mathrm{K}_{2} \mathrm{O}$ & 0.000 & 0.000 & 0.000 & 0.000 & 0.000 & 0.34 & 0.12 & 0.17 & 0 & $\begin{array}{l}.1 \\
0\end{array}$ & 0 & 0.01 & 0.01 & 0 & 0 & 0.25 & 0.32 & 0.23 & 7.06 & 7.98 \\
\hline CalcTotal & 100.25 & 100.41 & 99.85 & 100.59 & 100.51 & 98.44 & 97.74 & 98.13 & 100.69 & 100.71 & 100.38 & 100.35 & 100.69 & 100.53 & 100.32 & 97.83 & 97.85 & 98.68 & 94.3 & 95.73 \\
\hline Mg\# & 67.567 & 71.014 & 68.067 & 72.548 & 73.685 & 64.392 & 70.311 & 71.168 & 61.838 & 61.721 & 66.588 & 68.02 & 67.648 & 65.906 & 68.332 & 65.478 & 60.374 & 65.149 & 64.196 & 66.563 \\
\hline
\end{tabular}

Table 6 (continued).

\begin{tabular}{|c|c|c|c|c|c|c|c|c|c|c|c|c|c|c|c|c|c|}
\hline \multirow{4}{*}{$\begin{array}{l}\text { Text. type: } \\
\text { Mineral }\end{array}$} & \multirow{2}{*}{$\begin{array}{l}\begin{array}{l}921 \mathrm{E}-7 \mathrm{R}-2, \\
94-100 \mathrm{~cm}\end{array} \\
0\end{array}$} & \multicolumn{6}{|c|}{$921 \mathrm{E}-3 \mathrm{R}-1,3-9 \mathrm{~cm}$} & \multicolumn{3}{|c|}{$923 \mathrm{~A}-16 \mathrm{R}-4,85-89 \mathrm{~cm}$} & \multicolumn{4}{|c|}{$923 \mathrm{~A}-11 \mathrm{R}-1,95-101 \mathrm{~cm}$} & \multicolumn{3}{|c|}{$923 \mathrm{~A}-3 \mathrm{R}-2,51-57 \mathrm{~cm}$} \\
\hline & & 3 & 3 & 3 & 3 & 3 & 3 & 2 & 2 & 0 & 2 & 4 & 4 & 2 & 4 & 0 & 2 \\
\hline & $\mathrm{AM}$ & OPX & OPX & OPX & OPX & $\mathrm{AM}$ & $\mathrm{AM}$ & $\mathrm{OL}$ & $\mathrm{AM}$ & $\mathrm{AM}$ & $\mathrm{OL}$ & OPX & OPX & $\mathrm{AM}$ & OPX & $\mathrm{AM}$ & $\mathrm{AM}$ \\
\hline & Int & $\mathbf{P}$ & $\mathrm{R}$ & $\mathbf{P}$ & $\mathbf{R}$ & Incl & $\mathrm{R}$ & $\mathbf{P}$ & Int & Int & $\mathrm{P}$ & $\mathrm{P}$ & $\mathbf{R}$ & Incl & $\mathrm{P}$ & Int & Incl \\
\hline $\mathrm{Na}_{2} \mathrm{O}$ & 0.94 & 0.02 & 0.01 & 0.03 & 0.01 & 2.71 & 2.59 & 0.000 & 2.63 & 1.12 & 0.02 & 0.03 & 0 & 2.88 & 0.04 & 2.39 & 2.59 \\
\hline $\mathrm{Cr}_{2} \mathrm{O}_{3}$ & 0 & 0.01 & 0.01 & 0 & 0.02 & 0.11 & 0.16 & 0.000 & 0.12 & 0.000 & 0 & 0.03 & 0.04 & 0.09 & 0.01 & 0.02 & 0 \\
\hline $\mathrm{MgO}$ & 14.09 & 22.54 & 22.69 & 19.76 & 18.86 & 11.37 & 12.3 & 33.1 & 13.8 & 13.93 & 33.8 & 24.68 & 24.68 & 13.6 & 22.24 & 12.79 & 12.62 \\
\hline $\mathrm{Al}_{2} \mathrm{O}_{3}$ & 3.86 & 1.1 & 0.66 & 0.95 & 0.59 & 10.65 & 10.47 & 0.000 & 10.71 & 3.65 & 0.01 & 1.38 & 1.21 & 11.37 & 0.98 & 10.01 & 10.18 \\
\hline $\mathrm{SiO}_{2}$ & 50.41 & 52.38 & 52.79 & 51.75 & 51.45 & 42.44 & 43.16 & 37.18 & 43.19 & 49.85 & 37.65 & 53.74 & 53.53 & 42.35 & 53.04 & 43.21 & 43.24 \\
\hline $\mathrm{CaO}$ & 9.97 & 1.14 & 1.04 & 1.25 & 1.38 & 10.66 & 10.92 & 0.03 & 11.23 & 10.36 & 0.02 & 1.83 & 1.2 & 11.45 & 1.57 & 10.88 & 10.84 \\
\hline $\mathrm{TiO}_{2}$ & 0.31 & 0.42 & 0.24 & 0.36 & 0.22 & 3.68 & 3.01 & 0.03 & 3.27 & 1.07 & 0.02 & 0.55 & 0.4 & 3.73 & 0.43 & 3.07 & 3.43 \\
\hline MnO & 0.44 & 0.43 & 0.55 & 0.64 & 0.69 & 0.2 & 0.19 & 0.43 & 0.13 & 0.38 & 0.45 & 0.41 & 0.42 & 0.17 & 0.55 & 0.21 & 0.17 \\
\hline $\mathrm{FeO}$ & 16.22 & 21.52 & 21.17 & 24.47 & 25.66 & 14.66 & 14.14 & 29.48 & 11.25 & 15.38 & 28.26 & 16.89 & 17.72 & 11.34 & 20.84 & 13.72 & 13.59 \\
\hline $\mathrm{NiO}$ & 0.01 & 0.01 & 0 & 0.01 & 0.03 & & 0.04 & 0.06 & 0.04 & 0. & 0.07 & 0 & 0.02 & 0.02 & 0.03 & 0.01 & 0.03 \\
\hline $\mathrm{K}_{2} \mathrm{O}$ & 0.13 & 0 & 0 & 0 & 0 & 0.13 & 0.21 & 0.000 & 0.26 & 0.19 & 0 & 0 & 0.03 & 0.11 & 0 & 0.23 & 0.19 \\
\hline CalcTotal & 96.4 & 99.56 & 99.17 & 99.22 & 98.92 & 96.61 & 97.18 & 100.31 & 96.65 & 95.96 & 100.28 & 99.53 & 99.34 & 97.1 & 99.7 & 96.55 & 96.88 \\
\hline Mg\# & 60.766 & 65.115 & 65.645 & 59.006 & 56.716 & 58.021 & 60.794 & 66.678 & 68.621 & 61.746 & 68.067 & 72.254 & 71.291 & 68.133 & 65.541 & 62.431 & 62.332 \\
\hline
\end{tabular}

Table 6 (continued).

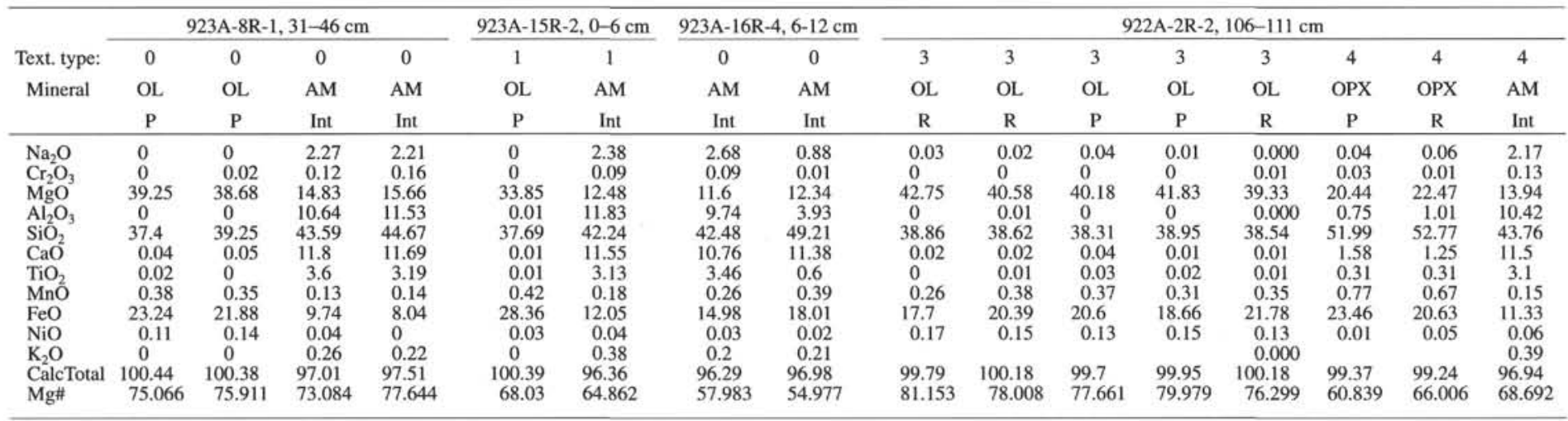


Table 6 (continued).

\begin{tabular}{|c|c|c|c|c|c|c|c|c|c|c|c|c|c|c|c|c|c|c|c|c|c|}
\hline \multirow[b]{2}{*}{ Text. type: } & \multicolumn{12}{|c|}{$922 \mathrm{~A}-2 \mathrm{R}-6,18-25 \mathrm{~cm}$} & \multicolumn{9}{|c|}{$922 \mathrm{~A}-3 \mathrm{R}-1,63-66 \mathrm{~cm}$} \\
\hline & 1 & 1 & 1 & 3 & 3 & 1 & 3 & 0 & 3 & 3 & 1 & 1 & 4 & 1 & 1 & 4 & 4 & 4 & 4 & 4 & 1 \\
\hline \multirow[t]{2}{*}{ Mineral } & $\mathrm{OL}$ & $\mathrm{OL}$ & OL & OPX & OPX & OPX & AM & $\mathrm{AM}$ & $\mathrm{AM}$ & $\mathrm{AM}$ & $\mathrm{AM}$ & $\mathrm{AM}$ & OL & $\mathrm{OL}$ & $\mathrm{OL}$ & OPX & OPX & OPX & $\mathrm{AM}$ & $\mathrm{AM}$ & $\mathrm{AM}$ \\
\hline & P & $\mathrm{R}$ & P & P & $\mathrm{P}$ & $\mathrm{R}$ & $\mathrm{R}$ & Int & & Int & Int & Int & $\mathrm{P}$ & $\mathrm{P}$ & $\mathrm{P}$ & $P$ & $P$ & R & $\mathrm{R}$ & R & Int \\
\hline $\mathrm{Na}_{2} \mathrm{O}$ & 0.000 & 0.000 & 0.01 & 0.03 & 0.03 & 0.01 & 2.57 & 1.55 & 2.45 & 2.4 & 2.51 & 2.71 & 0.01 & 0 & 0 & 0.01 & 0.01 & 0.02 & 2.68 & 2.77 & 2.58 \\
\hline $\mathrm{Cr}_{2} \mathrm{O}_{3}$ & 0.01 & 0.000 & 0.000 & 0.01 & 0.000 & 0.07 & 0.05 & 0.01 & 0.27 & 0.04 & 0.31 & 0.97 & 0 & 0 & 0 & 0 & 0.01 & 0.01 & 0.16 & 0 & 0.37 \\
\hline $\mathrm{MgO}$ & 37.76 & 34.5 & 40.93 & 25.000 & 21.05 & 30.96 & 15.34 & 11.95 & 12.29 & 15.24 & 13.94 & 16.14 & 42.58 & 44.91 & 33.11 & 23.11 & 22.85 & 24.7 & 16.54 & 10.52 & 16.81 \\
\hline $\mathrm{Al}_{2} \mathrm{O}_{3}$ & 0.000 & 0.000 & 0.000 & 0.88 & 0.87 & 1.33 & 12.92 & 6.46 & 10.76 & 9.81 & 10.93 & 11.29 & 0 & 0 & 0 & 0.77 & 0.83 & 0.99 & 12.4 & 13.39 & 11.77 \\
\hline $\mathrm{SiO}_{2}$ & 37.73 & 37.06 & 38.83 & 53.62 & 52.25 & 55.32 & 43.27 & 47.28 & 43.21 & 44.66 & 43.08 & 43.07 & 38.72 & 39.2 & 35.99 & 51.41 & 52.35 & 52.28 & 43.38 & 41.23 & 42.94 \\
\hline $\mathrm{CaO}$ & 0.02 & 0.02 & 0.05 & 2.02 & 1.88 & 0.78 & 10.56 & 10.76 & 11.000 & 11.11 & 11.73 & 11.86 & 0.02 & 0.06 & 0.05 & 1.29 & 1.12 & 1.33 & 11.12 & 11.45 & 12.09 \\
\hline $\mathrm{TiO}_{2}$ & 0.000 & 0.02 & 0.01 & 0.39 & 0.34 & 0.29 & 2.72 & 1.52 & 2.9 & 3.19 & 3.35 & 3.2 & 0.03 & 0 & 0.02 & 0.32 & 0.34 & 0.35 & 3.55 & 0.2 & 4.24 \\
\hline $\mathrm{MnO}$ & 0.38 & 0.42 & 0.29 & 0.52 & 0.58 & 0.28 & 0.2 & 0.32 & 0.26 & 0.23 & 0.2 & 0.08 & 0.28 & 0.25 & 0.56 & 0.63 & 0.7 & 0.57 & 0.11 & 0.29 & 0.08 \\
\hline $\mathrm{FeO}$ & $\begin{array}{r}0.00 \\
23.66\end{array}$ & 27.73 & 19.3 & 17.12 & 22.60 & 10.78 & 9.39 & 17.3 & 14.5 & 9.87 & 10.75 & 6.58 & 18.8 & 15.82 & 29.94 & 20.8 & 22 & 18.86 & 6.79 & 16.08 & 5.48 \\
\hline $\mathrm{NiO}$ & 0.14 & 0.12 & 0.17 & 0.04 & 0.000 & 0.04 & 0.05 & 0.000 & 0.02 & 0.1 & 0.02 & 0.02 & 0.15 & 0.22 & 0.07 & $\begin{array}{r}20.01 \\
0.01\end{array}$ & 0.03 & $\begin{array}{l}10.00 \\
0\end{array}$ & 0.05 & 0.04 & 0.04 \\
\hline $\mathrm{K}_{2} \mathrm{O}$ & $\begin{array}{l}0.14 \\
0.000\end{array}$ & 0.000 & 0.000 & 0.000 & $\begin{array}{l}0.0000 \\
0.000\end{array}$ & $\begin{array}{l}0.04 \\
0.000\end{array}$ & 0.24 & 0.28 & 0.24 & $\begin{array}{l}0.1 \\
0.2\end{array}$ & 0.25 & $\begin{array}{l}0.17 \\
0.17\end{array}$ & 0 & 0 & 0 & 0 & 0 & 0 & 0.24 & $\begin{array}{l}0.04 \\
0.12\end{array}$ & $\begin{array}{l}0.04 \\
0.19\end{array}$ \\
\hline CalcTotal & 99.71 & 99.86 & 99.58 & 99.63 & 99.62 & 99.86 & 97.3 & 97.44 & 97.9 & 96.85 & 97.07 & 96.09 & 100.6 & 100.46 & 99.74 & 98.36 & 100.23 & 99.12 & 97.03 & 96.09 & 96.59 \\
\hline Mg\# & 73.987 & 68.925 & 79.082 & 72.25 & 62.408 & 83.662 & 74.452 & 55.174 & 60.172 & 73.35 & 69.792 & 81.381 & 80.147 & 83.499 & 66.347 & 66.452 & 64.927 & 70.006 & 81.294 & 53.846 & 84.549 \\
\hline
\end{tabular}

Table 6 (continued).

\begin{tabular}{|c|c|c|c|c|c|c|c|c|c|c|c|c|c|c|c|c|c|c|c|c|c|}
\hline \multirow{4}{*}{$\begin{array}{c}\text { Text. type: } \\
\text { Mineral }\end{array}$} & \multicolumn{2}{|c|}{$921 \mathrm{~B}-3 \mathrm{R}-1,33-36 \mathrm{~cm}$} & \multicolumn{4}{|c|}{ 921B-3R-1, 94-99 cm } & \multicolumn{15}{|c|}{$922 \mathrm{~B}-1 \mathrm{~W}-1,109-115 \mathrm{~cm}$} \\
\hline & 3 & 3 & 2 & 3 & 3 & 2 & 1 & 1 & 1 & 4 & 4 & 4 & 3 & 3 & 3 & 4 & 1 & 3 & 3 & 4 & 1 \\
\hline & OPX & $\mathrm{AM}$ & $\mathrm{OL}$ & OPX & OPX & $\mathrm{AM}$ & $\mathrm{OL}$ & OL & $\mathrm{OL}$ & $\mathrm{OL}$ & $\mathrm{OL}$ & $\mathrm{OL}$ & OPX & OPX & OPX & OPX & $\mathrm{AM}$ & $\mathrm{AM}$ & $\mathrm{AM}$ & $\mathrm{AM}$ & $\mathrm{AM}$ \\
\hline & P & Int & R & $P$ & P & Int & $\mathrm{P}$ & P & $P$ & $P$ & $\mathrm{R}$ & $\mathrm{R}$ & $\mathrm{P}$ & $\mathrm{P}$ & $\mathrm{R}$ & $\mathrm{R}$ & $\mathrm{R}$ & $\mathrm{R}$ & $\mathrm{R}$ & $\mathrm{R}$ & Int \\
\hline $\mathrm{Na}_{2} \mathrm{O}$ & 0.04 & 2.79 & 0.000 & 0.05 & 0.03 & 2.67 & 0.01 & 0 & 0.01 & 0.01 & 0 & 0.01 & 0.05 & 0.01 & 0.02 & 0.02 & 2.85 & 2.84 & 0.16 & 2.72 & 2.66 \\
\hline $\mathrm{Cr}_{2} \mathrm{O}_{3}$ & 0.01 & 0.01 & 0.000 & 0.03 & 0.02 & $\begin{array}{r}0.09 \\
\end{array}$ & 0.01 & 0 & 0 & 0.01 & 0 & 0 & 0.01 & 0.03 & $\begin{array}{r}0.000 \\
\end{array}$ & 0.04 & 0.56 & $\begin{array}{r}0.02 \\
\end{array}$ & 0.000 & $\begin{array}{r}0.12 \\
561\end{array}$ & $\begin{array}{r}0.52 \\
560\end{array}$ \\
\hline $\mathrm{MgO}$ & 20.87 & 11.9 & 31.61 & 23.6 & 19.22 & 13.88 & 33.68 & 41.04 & 43.5 & 45.37 & 45.05 & 38.93 & 20.32 & 24.85 & 25.53 & 28.55 & 15.49 & 14.09 & 20.35 & 15.61 & 15.69 \\
\hline $\mathrm{Al}_{2} \mathrm{O}_{3}$ & 1.03 & 11.1 & 0.000 & 1.16 & $\begin{array}{r}0.56 \\
\end{array}$ & 10.29 & 0.000 & 0 & 0 & 0 & 0 & 0 & 0.8 & $\begin{array}{r}0.89 \\
\end{array}$ & 0.94 & 1.2 & 11.92 & 11.38 & 1.35 & 12.06 & 11.44 \\
\hline $\mathrm{SiO}_{2}$ & 52.46 & 42.78 & 36.44 & 53.43 & 51.85 & 44.39 & 36.46 & 38.52 & 38.47 & 39.07 & 39.42 & 37.54 & 52.06 & 53.41 & 53.55 & 54.12 & 42.54 & 42.49 & 52.35 & 42.78 & 42.77 \\
\hline $\mathrm{CaO}$ & 1.57 & 10.72 & 0.04 & 2.51 & 1.47 & 11.05 & 0.06 & 0.04 & 0.03 & 0.04 & 0.01 & 0.02 & 1.79 & 1.09 & 1.17 & 0.97 & 11.48 & 11.35 & 10.35 & 11.35 & 11.88 \\
\hline $\mathrm{TiO}_{2}$ & 0.35 & 4.64 & 0.01 & 0.44 & 0.31 & 3.86 & 0.000 & 0 & 0.02 & 0.02 & 0 & 0.02 & 0.36 & 0.26 & 0.28 & 0.31 & 3.9 & 3.74 & 0.37 & 3.63 & 4.17 \\
\hline $\mathrm{MnO}$ & 0.61 & 0.19 & 0.51 & 0.43 & 0.65 & 0.14 & 0.5 & 0.35 & 0.3 & 0.25 & 0.25 & 0.37 & 0.72 & 0.47 & 0.48 & 0.42 & 0.12 & 0.16 & 0.43 & 0.14 & 0.1 \\
\hline $\mathrm{FeO}$ & 23.46 & 14.5 & 32.02 & 18.4 & 25.68 & 11.66 & 28.2 & 20.85 & 17.72 & 15.53 & 15.81 & 23.5 & 23.14 & 17.45 & 16.63 & 14.28 & 7.1 & 9.53 & 12.46 & 8.4 & 6.98 \\
\hline $\mathrm{NiO}$ & 0.04 & 0.01 & 0.08 & 0.000 & 0.02 & 0.03 & 0.1 & 0.2 & 0.16 & 0.16 & 0.19 & 0.19 & 0.01 & 0.05 & 0.0 & 0.04 & 0.04 & 0.04 & 0.08 & 0.04 & 0.09 \\
\hline $\mathrm{K}_{2} \mathrm{O}$ & 0.01 & 0.18 & 0.000 & 0.02 & 0.000 & 0.15 & 0.000 & 0 & 0 & 0 & 0 & 0.01 & 0.01 & 0.000 & 0.000 & 0.02 & 0.29 & 0.27 & 0.000 & 0.35 & 0.39 \\
\hline CalcTotal & 100.44 & 98.8 & 100.72 & 100.06 & 99.81 & 98.2 & 99.02 & 101.02 & 100.21 & 100.45 & 100.74 & 100.59 & 99.27 & 98.51 & 98.64 & 99.97 & 96.29 & 95.9 & 97.88 & 97.21 & 96.68 \\
\hline $\mathrm{Mg} \#$ & 61.329 & 59.399 & 63.759 & 69.573 & 57.158 & 67.967 & 68.043 & 77.819 & 81.401 & 83.888 & 83.551 & 74.705 & 61.02 & 71.742 & 73.237 & 78.081 & 79.544 & 72.495 & 74.433 & 76.804 & 80.032 \\
\hline
\end{tabular}




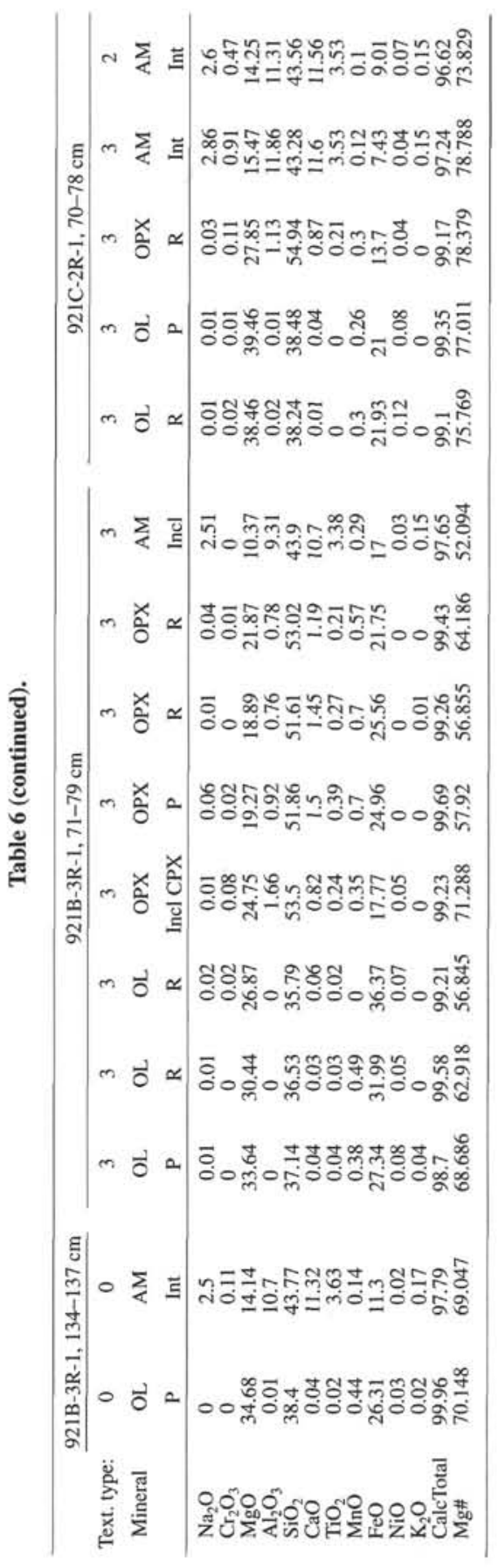

blasts. The euhedral grains are iron-rich $(\mathrm{Mg} \#$ between 0.54 and $0.58)$, the anhedral grains near olivine are iron-poor $(\mathrm{Mg} \#$ between 0.76 and 0.79 ). Olivine from the undeformed olivine gabbro has similarly high Mg\#. Dynamically recrystallized orthopyroxene has intermediate $\mathrm{Mg} \#$ values $(0.57-0.63$; Table 3 ; Fig. $9 \mathrm{C})$. We propose that the high-Mg\# orthopyroxene was produced by a reaction between xenocrysts of magnesian olivine and the gabbronoritic parental melt. The low-Mg\# orthopyroxene would have crystallized directly from this melt. Slightly higher Mg\# in orthopyroxene neoblasts could then reflect recrystallization in the presence of interstitial residual melt with slightly higher magnesium contents than the gabbronoritic parental melt. These slightly higher magnesium contents could be caused by the fractionation of iron oxides, or by chemical exchanges between the melt and the surrounding olivine gabbro.

\section{DISCUSSION AND CONCLUSIONS}

Ductile shear zones cored at Sites 921-923 localize preferentially in gabbronoritic intervals (although there are undeformed gabbronoritic intervals in the core; Fig. 3). The least-evolved gabbroic lithologies (troctolites) are rarely deformed, and the most-evolved lithologies (leucocratic segregations) are not deformed. A close look at ductile shear zones and at their mineral chemistry suggests that in many cases they developed in gabbronoritic dikelets intruded into lessevolved lithologies: (1) there are xenocrysts from these less-evolved rocks in some shear zones (Fig. 5A); (2) we interpret the rims of orthopyroxene that surround olivine xenocrysts as products of a reaction between these olivine xenocrysts and the gabbronoritic parental melt; and (3) high $\mathrm{Mg \#}$ in igneous pyroxenes in some shear zones are best explained by buffering of the gabbronoritic parental melt by the magnesium-rich host gabbro. In most cases, these sheared gabbronoritic intervals contain small euhedral igneous minerals (Figs. $5 \mathrm{D}, 5 \mathrm{E})$ and therefore probably had fine igneous grain sizes.

Recrystallized phase assemblages are similar to igneous ones in most deformed samples. This indicates that ductile deformation occurred in high-temperature nearly anhydrous conditions similar to magmatic conditions. Compositional variations in igneous and recrystallized minerals in many shear zones also suggest that ductile deformation took place with some residual melt present: variations in An content of recrystallized plagioclase, variations in $\mathrm{Mg \#}$ of recrystallized orthopyroxene, and the existence of undeformed leucocratic patches with sodium-rich plagioclase (Fig. 5B) are best explained by interactions between the deforming gabbro, and an interstitial melt of a more evolved sodium- and silica-rich composition. The presence of interstitial melt in shear zones during deformation would produce a strong rheological contrast between material in the shear zone and the surrounding rocks. It is therefore also consistent with observations that extensively deformed intervals in the core are commonly juxtaposed with undeformed or weakly deformed gabbros (Figs. 2A, 5A).

The range of gabbroic lithologies recovered at Sites 921-923 in the MARK area, their relative proportions in the core, the composition of igneous minerals, the preferred localization of ductile deformation in gabbronoritic lithologies, and the probable role of trapped fractionated melts in favoring this strain localization recall observations made at Site 735 in the Southwest Indian Ocean (Bloomer et al., 1991; Natland et al., 1991; Dick et al., 1991). Bloomer et al. (1991) proposed a schematic model for the crystallization of gabbroic rocks at this site. In Figure 12, we show a modified version of this model, adapted to fit our observations at Sites 921-923. This model shows an irregularly shaped magma body that crystallizes troctolitic cumulates on its margins and that is progressively cooled (Fig. 12A). As crystallization proceeds, the porosity that kept melt circulating through the cumulate pile is closed, and trapped melts begin to fractionate. In Figure 12B, the cumulate pile behaves as a solid transmitting tectonic stresses. Evolved residual melts are pressed out of the 
Figure 6. Average $\mathrm{Mg \#}$ in clinopyroxene vs. average An content in plagioclase for the variably deformed gabbroic rocks listed in Table 3 . Southwest Indian Ridge samples come from Hole 735B (Ozawa et al., 1991), and from other ridge and transform locations (Meyer et al., 1989). Ranges of compositional variations are shown for samples that do not plot on the tholeiitic differentiation trend. Ranges for other samples are listed in Table 3. CPX = clinopyroxene, $\mathrm{PLAG}=$ plagioclase .

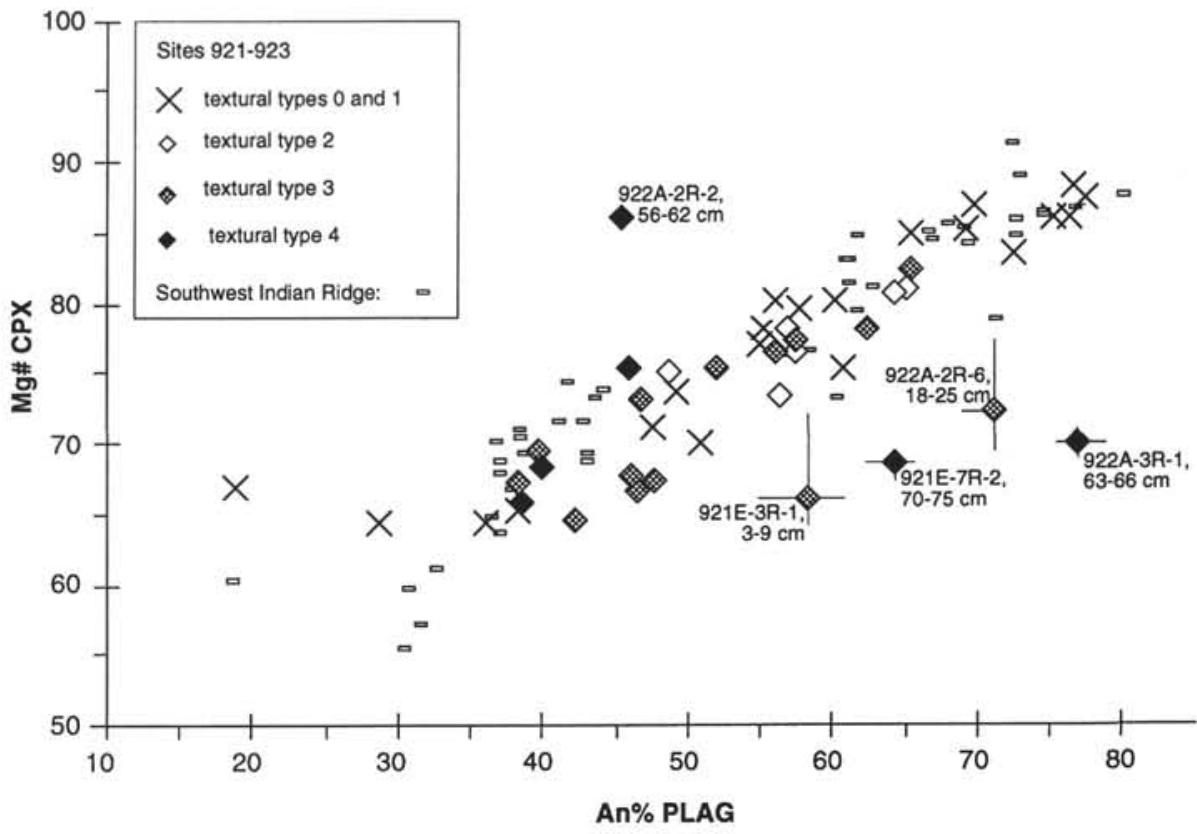

been active in the MARK area, but that we have not sampled them during Leg 153.

\section{ACKNOWLEDGMENTS}

velop between melt migration paths and stress patterns in the cumulate pile. As pointed out by Bloomer et al. (1991), and by Natland et al. (1991) for the Site 735 case, gravity could also play a role in controlling the migration of residual melts, iron-rich evolved melts being substantially denser than the magnesium-rich olivine gabbro and troctolite matrix. In Figure 12C, most residual melts have crystallized, only the very last leucocratic segregates are still liquid. Ductile deformation in the small shear zones that we cored in the MARK area appears to have stopped at this stage.

The core from Sites 921 to 923 lacks the meter- to decameterthick sheared intervals that were observed at Site 735 in the Southwest Indian Ocean (Dick et al., 1991; Cannat et al., 1991). Another difference that is striking concerns the involvement of high-temperature hydrothermal alteration products in the ductile deformation: sheared amphibolites are common at Site 735 (Stakes et al., 1991) but are virtually absent from the gabbroic core from the MARK area (Cannat, Karson, Miller, et al., 1995). The interpretation for Site 735 was that seawater-derived fluids had been introduced into the hot regions of the deforming axial lithosphere along large offset faults and thick shear zones that branched all the way up to the seafloor (Cannat et al., 1991; Mével and Cannat, 1991). Following this interpretation, the absence of such thick shear zones in the core recovered from Sites 921 to 923 could explain why amphibolite facies hydrothermal alteration is virtually lacking in this core (Cannat, Karson, Miller, et al., 1995). We should not conclude, however, that amphibolite facies alteration and sheared amphibolites that may have formed in and near thick ductile shear zones are absent in the MARK area gabbros. First, the core recovered from Sites 921 to 923 represents only about $30 \%$ of the material that was drilled at these sites (Table 1). It is therefore possible that thick shear zones were drilled through, but not recovered. Second, samples collected during the three submersible diving cruises devoted to the gabbroic outcrops in the vicinity of the drill sites do include amphibolitized gabbros and sheared amphibolites similar to the Site 735 samples (Karson and Dick, 1983; Marion, 1992; Gillis et al., 1993; I. Ghose et al., unpubl. data). It is therefore probable that thick shear zones similar to the ones at Site 735 have
We thank our two reviewers for their thorough and helpful work on the paper. We also thank the captain, the crew, and the drilling and technical staff of the JOIDES Resolution. Financial support for our work was provided by INSU-CNRS ("Géosciences marines" program).

\section{REFERENCES}

Auzende, J.-M., Cannat, M., Gente, P., Henriet, J.P., Juteau, T., Karson, J., Lagabrielle, Y., Mével, C., and Tivey, M., 1993. Affleurements des roches profondes de la croûte océanique et du manteau sur le mur Sud de Acad. Sci. Ser. 2, 317:1641-1648.

Bloomer, S.H., Meyer, P.S., Dick, H.J.B., Ozawa, K., and Natland, J.H., 1991. Textural and mineralogic variations in gabbroic rocks from Hole 735B. In Von Herzen, R.P., Robinson, P.T., et al., Proc. ODP, Sci. Results, 118: College Station, TX (Ocean Drilling Program), 21-39.

Cannat, M., 1993. Emplacement of mantle rocks in the seafloor at mid-ocean ridges. J. Geophys. Res., 98:4163-4172.

Cannat, M., and Casey, J.F., 1995. An ultramafic lift at the Mid-Atlantic Ridge: successive stages of magmatism in serpentinized peridotites from the $15^{\circ} \mathrm{N}$ region. In Vissers, R.L.M., and Nicolas, A. (Eds.), Mantle and wer), 5-34.

Cannat, M., Mével, C., and Stakes, D., 1991. Normal ductile shear zones at an oceanic spreading ridge: tectonic evolution of Site 735 gabbros (southwest Indian Ocean). In Von Herzen, R.P., Robinson, P.T., et al., Proc. ODP, Sci. Results, 118: College Station, TX (Ocean Drilling Program), 415-429.

Cannat, M., Karson, J.A., Miller, D.J., et al., 1995. Proc. ODP, Init. Repts., 153: College Station, TX (Ocean Drilling Program).

Dick, H.J.B., Meyer, P.S., Bloomer, S., Kirby, S., Stakes, D., and Mawer, C., 1991. Lithostratigraphic evolution of an in-situ section of oceanic Layer 3. In Von Herzen, R.P., Robinson, P.T., et al., Proc. ODP, Sci. Results, 118: College Station, TX (Ocean Drilling Program), 439-538. steady state emplacement of plutonic rocks at ridge-transform intersections. Eos, 62:406. la fracture Kane (Atlantique Central): observations par submersible. C.R. Lower Crust Exposed in Oceanic Ridges and Ophiolites: Dordrecht (Klu-

Dick, H.J.B., Thompson, G., and Bryan, W.B., 1981. Low angle faulting and 
Gente, P., Pockalny, R., Durand, C., Deplus, C., Maia, M., Ceuleneer, G., Mével, C., Cannat, M., and Laverne, C., 1995. Characteristics and evolution of the segmentation of the Mid-Atlantic Ridge between $20^{\circ} \mathrm{N}$ and $24^{\circ} \mathrm{N}$ during the last 10 million years. Earth Planet. Sci. Lett., 129:5571.

Helmstaedt, H., and Allen, J.M., 1977. Metagabbronorite from DSDP Hole 334: an example of high-temperature deformation and recrystallization near the Mid-Atlantic ridge. Can. J. Earth Sci., 14:886-898.

Ito, E., and Anderson, A.T., Jr., 1983. Submarine metamorphism of gabbros from the Mid-Cayman Rise: petrographic and mineralogic constraints on hydrothermal processes at slow-spreading ridges. Contrib. Mineral. Petrol., 82:371-388.

Karson, J.A., 1990. Seafloor spreading on the Mid-Atlantic Ridge: implications for the structure of ophiolites and oceanic lithosphere produced in slow-spreading environments. In Malpas, J., Moores, E.M., Panayiotou, A., and Xenophontos, C. (Eds.), Ophiolites: Oceanic Crustal Analogues: Proc. Symp. "Troodos 1987": Nicosia, Cyprus (Minist. Agric. Nat. Resour.), 547-555.

Karson, J.A., Thompson, G., Humphris, S.E., Edmond, J.M., Bryan, W.B., Brown, J.R., Winters, A.T., Pockalny, R.A., Casey, J.F., Campbell, A.C., Klinkhammer, G., Palmer, M.R., Kinzler, R.J., and Sulanowska, M.M., 1987. Along-axis variations in seafloor spreading in the MARK area. Nature, 328:681-685.

Mével, C., and Cannat, M., 1991. Lithospheric stretching and hydrothermal processes in oceanic gabbros from slow-spreading ridges. In Peters, T., Nicolas, A., and Coleman, R.J. (Eds.), Ophiolite Genesis and Evolution of the Oceanic Lithosphere. Petrol. Struct. Geol., 5:293-312.
Mével, C., Cannat, M., Gente, P., Marion, E., Auzende, J.-M., and Karson, J.A., 1991. Emplacement of deep crustal and mantle rocks on the west median valley wall of the MARK area (MAR $23^{\circ} \mathrm{N}$ ). Tectonophysics, 190:31-53.

Meyer, P.S., Dick, H.J.B., and Thompson, G., 1989. Cumulate gabbros from the Southwest Indian Ridge, $54^{\circ} \mathrm{S}-7^{\circ} 16^{\prime} \mathrm{E}$ : implications for magmatic processes at a slow spreading ridge. Contrib. Mineral. Petrol., 103:4463.

Natland, J.H., Meyer, P.S., Dick, H.J.B., and Bloomer, S.H., 1991. Magmatic oxides and sulfides in gabbroic rocks from Hole $735 \mathrm{~B}$ and the later development of the liquid line of descent. In Von Herzen, R.P., Robinson, P.T., et al., Proc. ODP, Sci. Results, 118: College Station, TX (Ocean Drilling Program), 75-111.

Ozawa, K., Meyer, P.S., and Bloomer, S.H., 1991. Mineralogy and textures of iron-titanium oxide gabbros and associated olivine gabbros from Hole 735B. In Von Herzen, R.P., Robinson, P.T., et al., Proc. ODP, Sci. Results, 118: College Station, TX (Ocean Drilling Program), 41-73.

Shipboard Scientific Party, 1989. Site 735. In Robinson, P.T., Von Herzen, R., et al., Proc. ODP, Init. Repts., 118: College Station, TX (Ocean Drilling Program), 89-222.

Stakes, D., Mével, C., Cannat, M., and Chaput, T., 1991. Metamorphic stratigraphy of Hole 735B. In Von Herzen, R.P., Robinson, P.T., et al., Proc. ODP, Sci. Results, 118: College Station, TX (Ocean Drilling Program), 153-180.
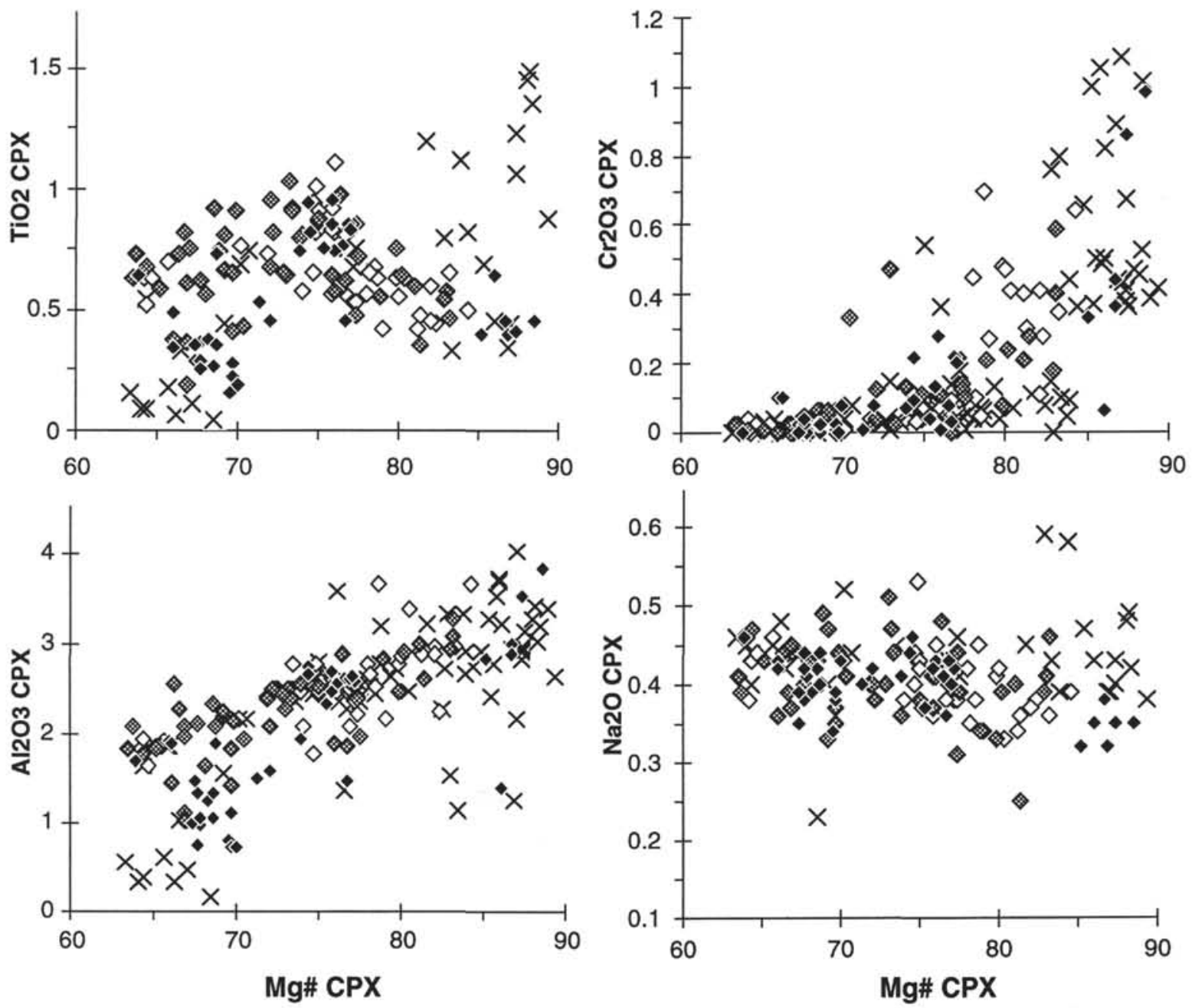

Figure. 7. Compositional variations in clinopyroxene from variably deformed gabbroic rocks cored at Sites 921, 922, and 923. Symbols and abbreviations are the same as in Figure 6. 


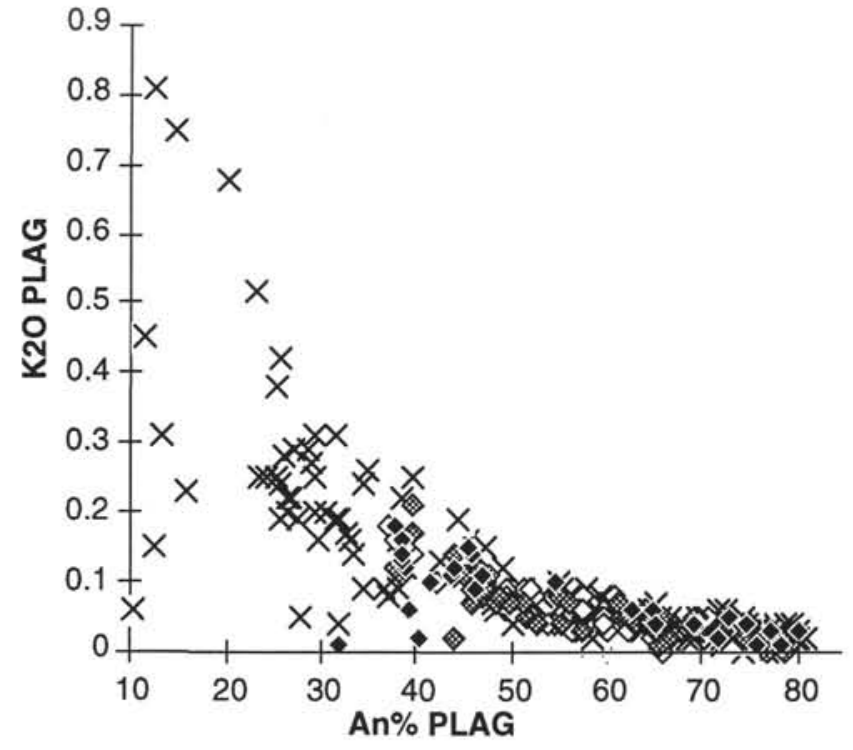

Figure. $8 . \mathrm{K}_{2} \mathrm{O} \%$ vs. An\% in plagioclase from variably deformed gabbroic rocks cored at Sites 921, 922, and 923. Symbols and abbreviations are the same as in Figure 6.

Date of initial receipt: 7 August 1995 Date of acceptance: 26 January 1996 Ms 153SR-006
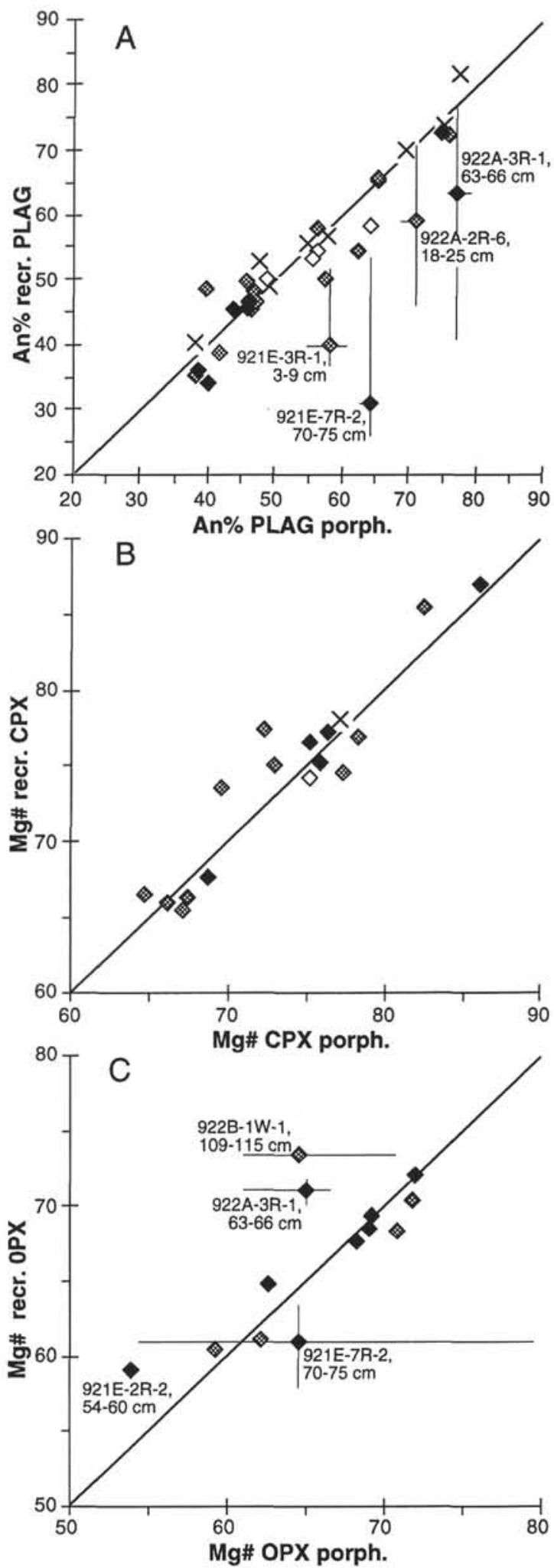

Figure 9. Average An\% and $\mathrm{Mg} \#$ of igneous and dynamically recrystallized (A) plagioclase, (B) clinopyroxene, and (C) orthopyroxene in deformed gabbroic rocks cored at Sites 921, 922, and 923. Oblique lines correspond to identical compositions for igneous and recrystallized grains. Ranges of variations are shown for selected samples in $\mathbf{A}$ and $\mathbf{C}$. Other ranges of variation are listed in Table 3. Symbols and abbreviations are the same as in Figure 6; $\mathrm{OPX}=$ orthopyroxene, recr. $=$ recrystallized, porph.$=$ porphyroclast . 

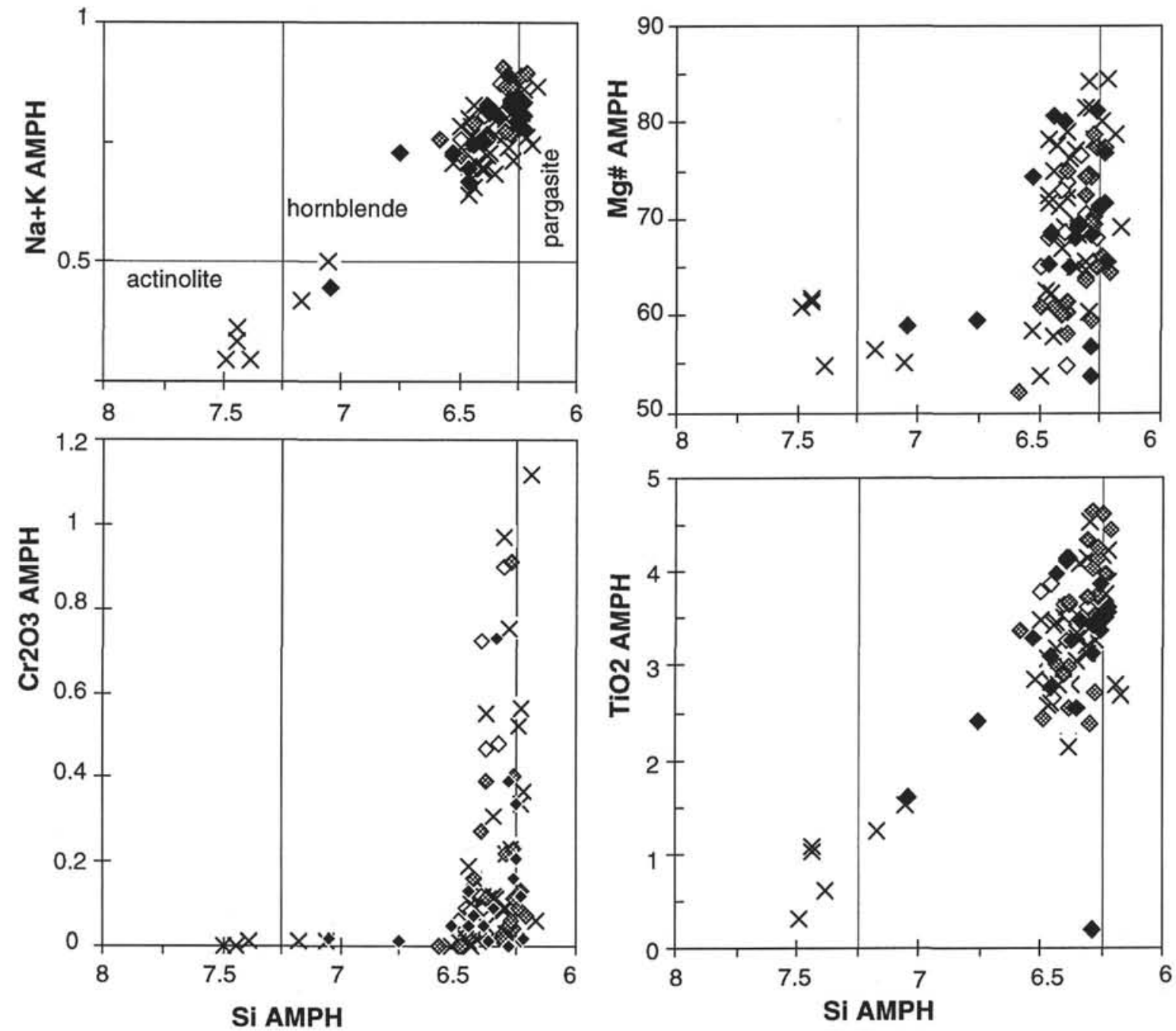

Figure 10. Compositional variations in brown to greenish brown amphibole from variably deformed gabbroic rocks cored at Sites 921,922 , and 923 . Symbols are the same as in Figure 6; AMPH = amphibole. 

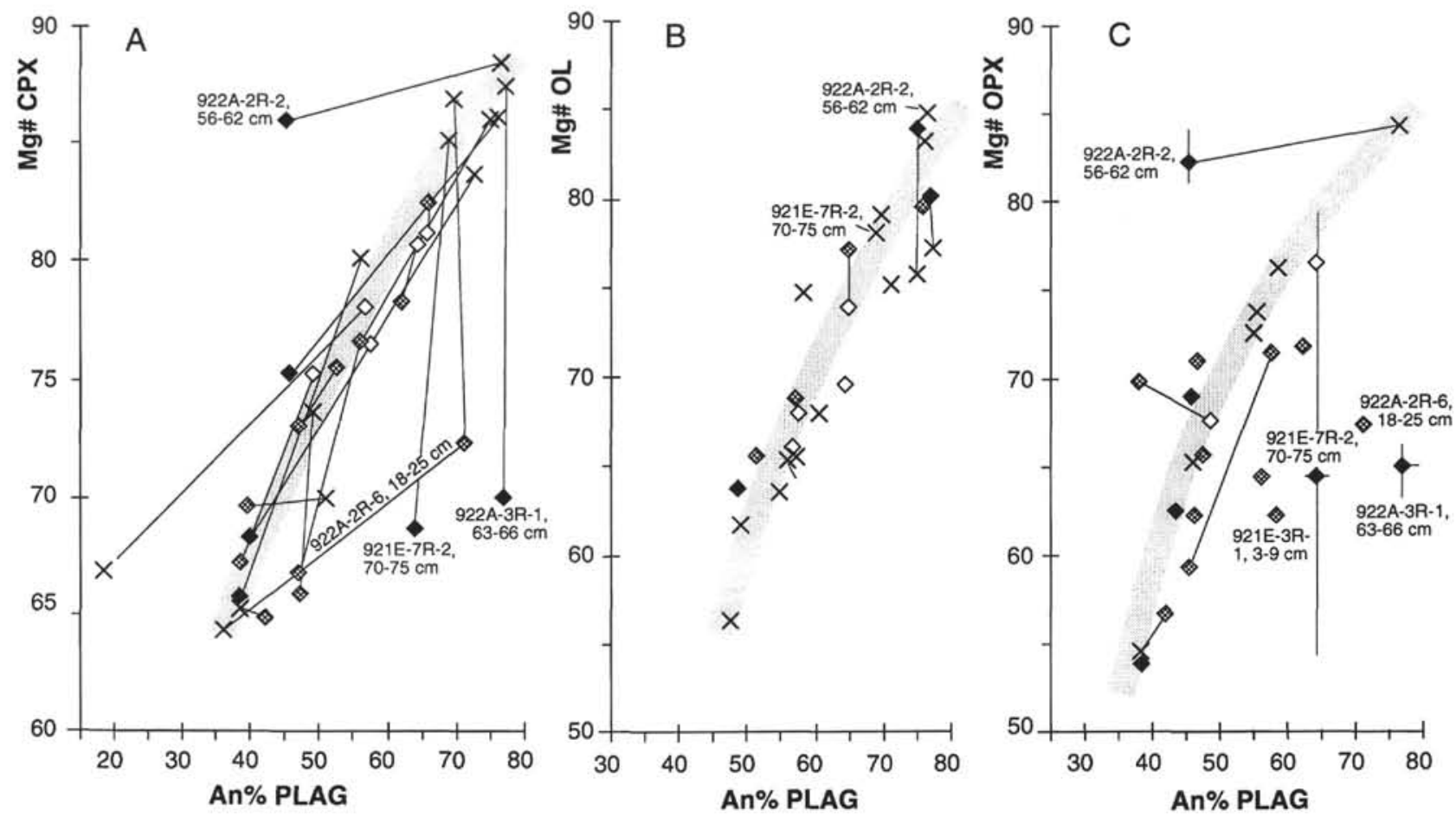

Figure 11. Compositional variations in (A) plagioclase and clinopyroxene, (B) plagioclase and olivine, and (C) plagioclase and orthopyroxene in deformed samples from Sites 921, 922, and 923 and in the less deformed gabbroic rocks that surround them. Mg\# and anorthite contents plotted in this figure are average values. Ranges of variations are shown for selected samples in C. Ranges of variations for other samples are listed in Table 3. Lines connect variably deformed lithologies from the same piece of core. The thick gray lines show inferred differentiation trends, drawn based on the composition of the least deformed samples. Symbols and abbreviations are the same as in Figures 6 and 9.
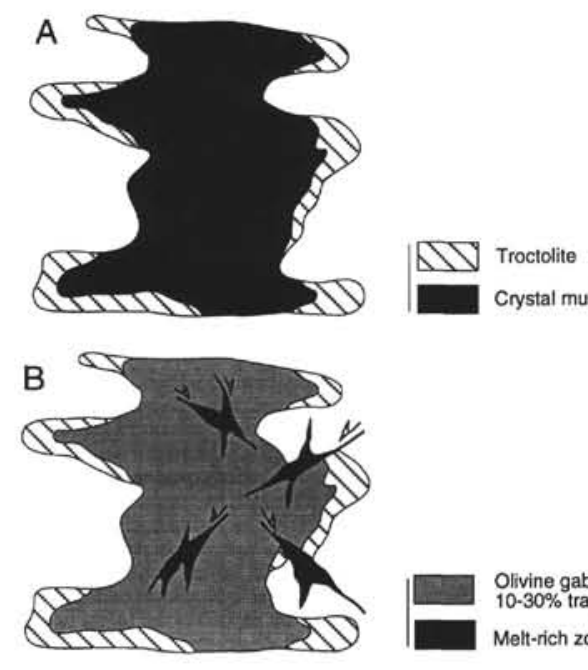

Crystal mush
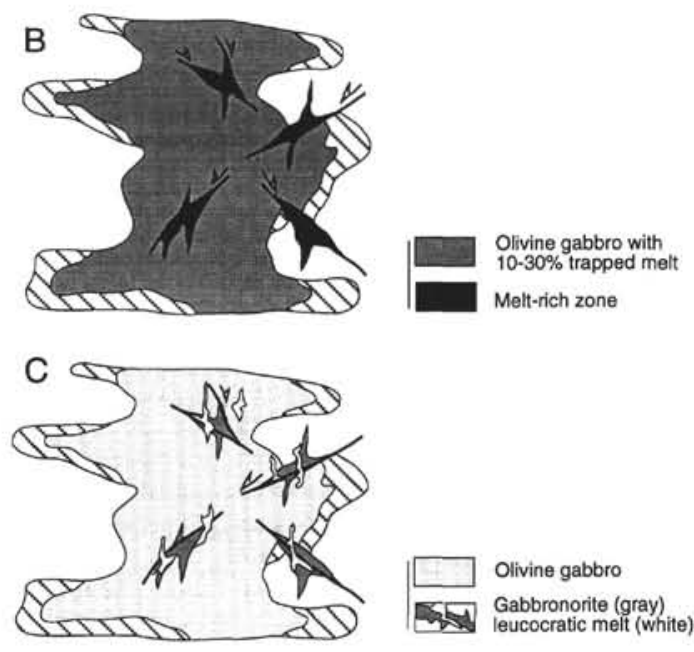

Olivine gabbro

Gabbronorite (gray)

Figure 12. Schematic model, initially proposed by Bloomer et al. (1991) for the crystallization of gabbroic rocks at Site 735 , and modified to fit the observations made on core from the MARK area. See text for an explanation of $\mathbf{A}$ through $\mathbf{C}$. 